
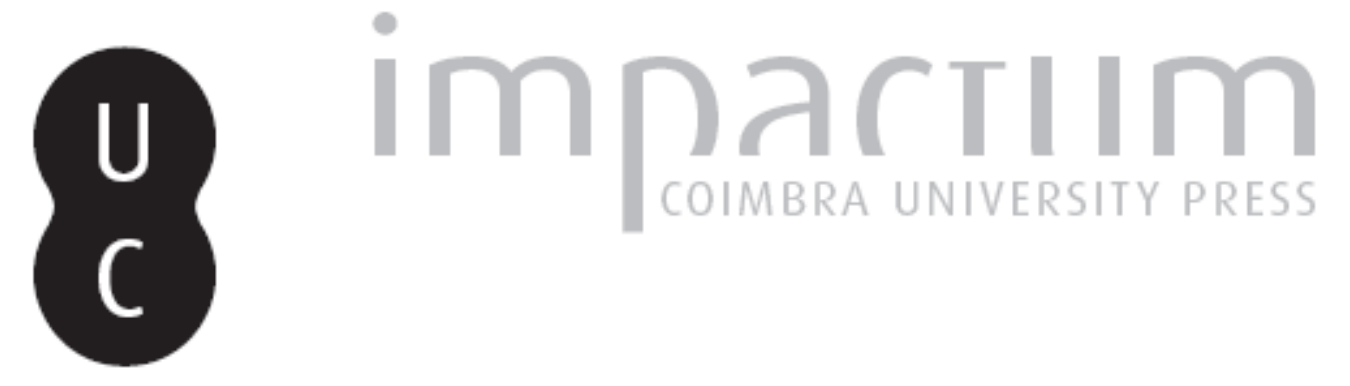

El sistema europeo de derechos fundamentales tras la entrada en vigor del tratado de
Lisboa

Autor(es): $\quad$ Martín-Retortillo Baquer, Lorenzo

Publicado por: Universidade Católica de Petrópolis

URL persistente:

URI:http://hdl.handle.net/10316.2/33816

DOI:

DOI:http://dx.doi.org/10.14195/2175-0947_3-1_7

Accessed : $\quad$ 26-Apr-2023 15:20:54

A navegação consulta e descarregamento dos títulos inseridos nas Bibliotecas Digitais UC Digitalis, UC Pombalina e UC Impactum, pressupõem a aceitação plena e sem reservas dos Termos e Condições de Uso destas Bibliotecas Digitais, disponíveis em https://digitalis.uc.pt/pt-pt/termos.

Conforme exposto nos referidos Termos e Condições de Uso, o descarregamento de títulos de acesso restrito requer uma licença válida de autorização devendo o utilizador aceder ao(s) documento(s) a partir de um endereço de IP da instituição detentora da supramencionada licença.

Ao utilizador é apenas permitido o descarregamento para uso pessoal, pelo que o emprego do(s) título(s) descarregado(s) para outro fim, designadamente comercial, carece de autorização do respetivo autor ou editor da obra.

Na medida em que todas as obras da UC Digitalis se encontram protegidas pelo Código do Direito de Autor e Direitos Conexos e demais legislação aplicável, toda a cópia, parcial ou total, deste documento, nos casos em que é legalmente admitida, deverá conter ou fazer-se acompanhar por este aviso.

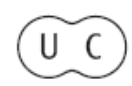



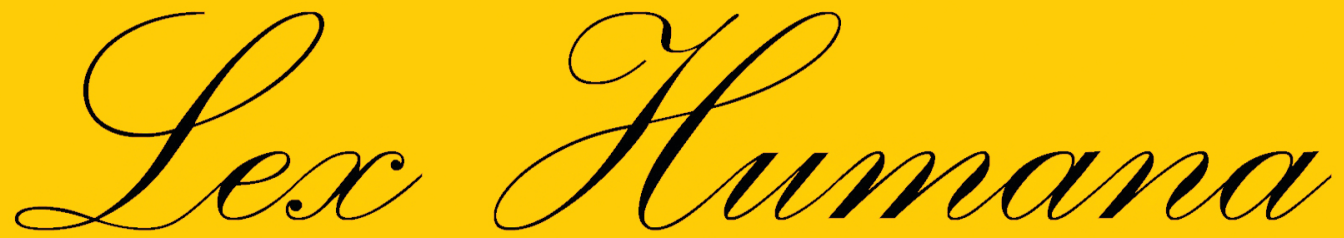

Revista do Programa de Pós-Graduação em Direito da UCP

ISSN(e) 2175-0947

Universidade Católica de Petrópolis Rua Benjamin Constant, 213 - Petrópolis - Centro CEP 25610-130

Tel: (24) 2244-4000 E-mail: lexhumana@ucp.br 


\title{
EL SISTEMA EUROPEO DE DERECHOS FUNDAMENTALES TRAS LA ENTRADA EN VIGOR DEL TRATADO DE LISBOA ${ }^{1}$
}

\author{
Lorenzo Martín-Retortillo Baquer ${ }^{2}$
}

Resumen: En 1947 se pusieron las bases de lo que llegaría a ser la Unión Europea, a modo de organización comercial para sectores concretos, complejo que iría creciendo, ampliándose los fines y la organización, a la par que se fraguaba un complejo ordenamiento jurídico. Se hizo necesario alcanzar una declaración de derechos que incluyera los modernos derechos sociales. En el trabajo se estudia la compleja historia de la obtención de la declaración, la "Carta de Derechos Fundamentales de la Unión Europea”, que, al fin, entraría en vigor el 1.XII.2009, a la par que el último de los Tratados de la Unión, el Tratado de Lisboa.

Palabras clave: Declaración de derechos, derechos humanos, derechos sociales, unión comercial, Unión Europea.

Abstract: The European Union was founded in 1947 as a concrete trade organization but it started to grown. The aims and the organization had increased and in the meantime a complex law system was set up. It was convenient to get a solid bill of rights including the modern social rights. The paper studies the complicate story of how to obtain the bill of rights -the "Carta of Fundamentals Rights of the European Union"- which formally came into effect the 1.XII.2099 at the same time that the last Treaty of the Union, the Treaty of Lison.

Keywords: Bill of rights, European Union, human rights, social rights, commerce union.

\footnotetext{
${ }^{1}$ Artigo recebido em 07/06/2011 e aprovado para publicação pelo Conselho Editorial em 01/07/2011.

2 Doutor Honoris Causa pela Universidad de Bolonia e professor catedrático emérito de Direito Administrativo da Universidade Complutense de Madri. Foi Senador constituinte na Constituição Espanhola de 1978. E-mail: lmretor@der.ucm.es.
} 


\section{PROEMIO}

1. Cada vez está más presente en nuestra sociedad el tema de los derechos humanos dado que abundan los acontecimientos cotidianos que aguzan la sensibilidad hacia ellos, atravesándose, sin duda, una fase de creencia y confianza en sus virtualidades. En lo que respecta al panorama jurídico conviene advertir, además de la enorme trascendencia del fenómeno, dado que se trataría de un título horizontal o transversal -como está de moda decir ahora-, que proyectaría su influencia sobre los más variados ámbitos del Derecho y sobre sus más diversos campos de aplicación.

2. Por otra parte, no me parece ocioso recordar al inicio, a modo de mínima orientación metodológica, que en nuestro tiempo el panorama jurídico está presidido por lo que puede denominarse la interconexión de los ordenamientos jurídicos, en el sentido de que la normas que rigen, por ejemplo, en cada punto concreto de España -aunque se trate de un fenómeno con vocación de universalidad-, habrán sido elaboradas por el Parlamento de la Comunidad Autónoma correspondiente, provendrán en parte de las Cortes Generales, pero también, en una gran medida, se han originado fuera, muy lejos acaso de nuestro territorio, como puedan ser los reglamentos o las directivas comunitarias, o quizá las interpretaciones depuradas por el Tribunal de Justicia de la Unión Europea o, acaso, por el Tribunal Europeo de Derechos Humanos. En suma, que el sistema de fuentes del Derecho ofrece bien ardua complejidad a la que conviene habituarse para superar sus dificultades ${ }^{3}$.

3. En línea con lo anterior, conviene advertir igualmente -como habrá ocasión de comprobar con detalle más adelante- que las regulaciones referentes a los derechos fundamentales tienen un origen bien diverso, siendo de destacar así una triple proveniencia de las mismas ${ }^{4}$. a) Hay que contar, ante todo, con el importante paquete que proviene de instrumentos internacionales, fruto los más significativos de la reacción que se produce en la profunda crisis

3 Me remito a lo señalado en mi libro, La interconexión de los ordenamientos jurídicos y el sistema de fuentes del derecho. Advertiré que al final, en la bibliografía, viene la cita íntegra de los libros y trabajos que se irán mencionando. $4 \quad$ Véase mi libro, Vías concurrentes para la protección de los derechos humanos. Perspectivas española y europeas. 
espiritual que se manifiesta tras la Segunda Guerra Mundial, destacando de entre ellos la Declaración Universal de Derechos Humanos, hecha por Naciones Unidas en 1948, así como sus instrumentos de desarrollo, de entre los cuales resaltaría, para el panorama europeo, el Convenio para la Protección de los Derechos Fundamentales y las Libertades Públicas, hecho por el Consejo de Europa, en Roma, el 4 de noviembre de $1950^{5}$, que cuenta para su salvaguarda con el Tribunal Europeo de Derechos Humanos, con sede en la ciudad francesa de Estrasburgo. b) Pero, descendiendo un tanto de las alturas, hoy resulta también de gran alcance la respuesta que ofrecen las Constituciones de cada uno de los Estados, en una dirección rica antańo -las primeras Constituciones francesas, las enmiendas a la Constitución de los Estados Unidos de América del Norte, etc.- pero que ha adquirido notorio impulso también en las Constituciones aparecidas tras la Segunda Guerra Mundial. En el caso concreto de la Española de 1978 -siguiendo muy de cerca el modelo de la Constitución Italiana, de La Ley Fundamental de Bonn, o de la Constitución Portuguesa, entre otras-, es de destacar el completo Título Primero, "De los derechos y deberes fundamentales", con un rico contenido tanto en las previsiones sustantivas como jurisdiccionales, ordenándose aquéllas en tres escalones bien diferenciados. Pero habrá que contar también, c), con que el Derecho de las Comunidades Europeas, hoy transformadas en Unión Europea, a pesar de sus carencias iniciales, ha ido incorporando paulatinamente, y últimamente de forma bien intensa, un destacable paquete de respuestas en el campo de los derechos fundamentales. Esta tercera línea va a ser precisamente el objeto de estudio en el presente trabajo, lo que no nos impedirá tener en cuenta la presencia de los otros dos manantiales.

4. En el título del trabajo se hace referencia a "sistema" con toda intención. Cualquiera sabe que hoy el mundo de lo normativo, salvo cualificadas excepciones, es un auténtico caos. No sólo han proliferado las fuentes de producción -lo que se acaba de decir en el punto anterior es ya bien ilustrativo, y con frecuencia se han resaltado las disfunciones sistemáticas derivadas de la forma de producirse el Derecho de la Unión Europea-, sino que en el ámbito interno, con demasiada frecuencia, los legisladores, que han proliferado -y salvo señaladas excepciones, insistohacen gala de una incontinencia tantas veces rayana en la improvisación o en la falta de

\footnotetext{
$5 \quad$ Véase, por todos, la visión general de quién fue el primer juez español en el Tribunal, el profesor Eduardo GARCÍA DE ENTERRÍA, La significación general del Convenio Europeo de Derechos Humanos, 29 ss.
} 
maduración de los textos propuestos. El intentar buscar sistema en panorama tan revuelto puede parecer así intento ciclópeo cuando no pretensión vana, tema constante de preocupación lo que me lleva a evocar las clarividentes páginas de Fernando Sainz Moreno y, bien recientemente, de Piedad García Escudero. Pero entiendo, con modestia y sinceridad, que es función de los estudiosos intentar ordenar lo revuelto y aspirar a introducir, aunque sólo sea, algunas dosis de sistema.

\section{A MODO DE INTRODUCCIÓN: IMPORTANTES AFIRMACIONES EN EL NUEVO TRATADO.}

5. Sentado lo anterior, y con afán de entrar en materia, hay que reconocer que la entrada en vigor por fin, el uno de diciembre de 2009, del Tratado de Lisboa de 13 de diciembre de 2007, tras tantos avatares y sobresaltos ${ }^{6}$, representa un importante hito en el proceso de afirmación de la Unión Europea. Los pasos esforzados y laboriosos necesarios para alcanzar tal meta, las ilusiones y aspiraciones que ha habido que dejar por el camino, las limitaciones o dificultades inherentes que supone, forman parte del siempre complejo proceso de afianzamiento de la organización europea, y han estado siempre vinculados a su avance. El nuevo Tratado representa la superación del desconcierto producido al rechazarse por algunos países ${ }^{7}$ el Proyecto de Tratado Instaurando una Constitución Europea, con la particularidad de que ahora Lisboa recupera la mayor parte de las previsiones de aquel proyecto, aunque haya habido que dejar de lado los aspectos simbólicos ${ }^{8}$ (desde el propio nombre de "Constitución", que a algunos desagradaba en lo que pudiera representar de debilitamiento de la ida de Estado). En una visión de conjunto, y ponderando unos y otros aspectos, entiendo que el resultado global es positivo y,

\footnotetext{
6 Recuérdese que en Irlanda, tras un primer fracaso, hubo que repetir el referendum necesario para el trámite de ratificación, y que, cuando todos los inconvenientes parecían haber sido superados, al final, el Presidente de la República Checa intentó bloquear la firma, aun cuando contaba con el acuerdo del Parlamento, lo que algunas consecuencias habría de tener, como más adelante se describirá.

7 Recuérdese el fracaso del correspondiente referéndum primero en Francia y luego en Holanda.

8 Recuérdese, no obstante, que 16 de los 27 Estados miembros de la UE -entre ellos, Espańa, aunque no el Reino Unido ni Francia- han adjuntado al Acta Final correspondiente al Tratado de Lisboa la Declaración no 52, "relativa a los símbolos de la Unión Europea", a cuyo tenor "declaran que la bandera que representa un círculo de doce estrellas doradas sobre fondo azul, el himno tomado del <Himno a la alegría $>$ de la Novena Sinfonía de Ludwig van Beethoven, la divisa <Unidad en la diversidad>, el euro en tanto que moneda de la Unión Europea y el Día de Europa el 9 de mayo, seguirán siendo, para ellos, los símbolos de la pertenencia común de los ciudadanos a la Unión Europea y de su relación con ésta".
} 
aunque la necesidad de abordar los retos de la actual crisis económica haga necesario el retoque de algunos puntos, hay que reconocer que, en un mundo cada vez más complejo, el Tratado de Lisboa permite a la Unión seguir avanzando, si se saben aprovechar las oportunidades.

6. Pues bien, dentro de los muchos contenidos que tiene que abarcar la normativa fundamental de organización tan compleja como la UE, responsable de tan variados y diversos cometidos, que afectan nada menos que a los 27 Estados integrantes -tan diversos y heterogéneos entre sí en tantos aspectos, por más que se haya producido una aproximación en otros-, me parece muy destacable por su importancia y significado la nueva ordenación que se da, por fin, y tras no pocos intentos, a la regulación de los derechos fundamentales. Convendrá resaltar este dato desde el inicio: no se ha hablado demasiado de ello en los medios de comunicación, ni ha trascendido apenas a la opinión pública, pero una de las notas destacables del Tratado de Lisboa es que aborda con decisión la importante parcela de los derechos fundamentales.

¿Cómo se hace, en efecto, el reconocimiento de los derechos fundamentales? En este punto se impone hacer referencia a tres diferentes opciones, connaturales al Tratado, que confluyen en el afianzamiento de los derechos fundamentales. Lo cual evidencia la exuberancia de respuestas, testimonio también de un cierto desorden, lo que nos hace pensar en la necesidad de intentar sistema, a que antes se aludía. $\mathrm{Y}$ es que hay abundancia de respuestas. De los dos Tratados que integran hoy el sistema básico de la UE, el Tratado de la Unión, que integra las grandes afirmaciones, nos sorprende en sus inicios, en su nueva redacción ${ }^{9}$ por supuesto, cuando en. el artículo 2 -dentro de las “Disposiciones Comunes" del Título I-, a modo de basamento y fundamento de todo el sistema ${ }^{10}$, se señala:

\footnotetext{
$9 \quad$ Para entender la organización jurídica de la UE tras el Tratado de Lisboa, es útil tener presente lo que se dispone en el párrafo 3 del artículo 1 del -nuevamente redactado y muy remozado- TUE: "La Unión se fundamenta en el presente Tratado y en el Tratado de Funcionamiento de la Unión Europea (en lo sucesivo denominados <los Tratados $>$ ). Ambos tienen el mismo valor jurídico. La Unión sustituirá y sucederá a la Comunidad Europea”. Debiendo recordarse igualmente que ambos Tratados se complementan con numerosos "protocolos" $y$ "declaraciones", a alguno de los cuales se aludirá a lo largo del trabajo.

10 Un poco, en la metodología de la corriente constitucional de la que es buena muestra el artículo 10.1 CE que, en el pórtico del Titulo I, en el que van a abordarse los derechos fundamentales, afirmará sentando las bases: "La dignidad de la persona, los derechos inviolables que le son inherentes, el libre desarrollo de la personalidad, el respeto a la ley y a los derechos de los demás son el fundamento del orden político y de la paz social”. Nótese la coincidencia en la mención a "la dignidad" humana o de la persona, y al "respeto de los derechos".
} 
"La Unión se fundamenta en los valores de respeto a la dignidad humana, libertad, democracia, igualdad, Estado de Derecho y respeto de los derechos humanos, incluidos los derechos de las personas pertenecientes a minorías. Estos valores son comunes a los Estados miembros en una sociedad caracterizada por el pluralismo, la no discriminación, la tolerancia, la justicia, la solidaridad y la igualdad entre mujeres y hombres"11.

Dicho lo cual, casi a continuación -a)-, el artículo 6 concentra pronunciamientos decisivos:

“1. La Unión reconoce los derechos, libertades y principios enunciados en la Carta de los Derechos Fundamentales de 7 de diciembre de 2000, tal y como fue adaptada el 12 de diciembre de 2007 en Estrasburgo, la cual tendrá el mismo valor jurídico que los Tratados"12.

b). Desde otra perspectiva, en relación también con otra aspiración largo tiempo auspiciada, el apartado 2 del artículo 6 incluye el siguiente compromiso:

“2. La Unión se adherirá al Convenio Europeo para la Protección de los Derechos Humanos y de las Libertades Fundamentales. Esta adhesión no modificará las competencias de la Unión que se definen en los Tratado”".

Si las dos últimas referencias constituyen novedades muy destacables, aludiré por último por el momento-, a una nueva perspectiva interesante, complementaria -e independiente- de las

\footnotetext{
11 Parte de este precepto estaba ya presente en el artículo 6.1 del TUE en su anterior redacción, pero se han añadido significativas afirmaciones.

12 Por razón de sistemática, y adelantándonos a lo que luego se dirá, conviene recordar que la importante proclamación que acaba de transcribirse, con innegable tensión ampliatoria, se complementa con dos párrafos de neta finalidad restrictiva o, cuando menos, delimitadora. En el párrafo segundo del apartado primero se puntualiza que "Las disposiciones de la Carta no ampliarán en modo alguno las competencias de la Unión tal como se definen en los Tratados". Por su parte, en el párrafo segundo, se establece: "Los derechos, libertades y principios enunciados en la Carta se interpretarán con arreglo a las disposiciones generales del título VII de la Carta por las que se rige su interpretación y aplicación y teniendo debidamente en cuenta las explicaciones a que se hace referencia en la Carta, que indican las fuentes de dichas disposiciones".
} 
anteriores, ya presente en el ordenamiento comunitario ${ }^{13}$. Se trata ahora $-\mathrm{c}$ )- del apartado 3 del citado artículo 6:

“3. Los derechos fundamentales que garantiza el Convenio Europeo para la Protección de los Derechos Humanos y de las Libertades Fundamentales y los que son fruto de las tradiciones constitucionales comunes a los Estados miembros formarán parte del derecho de la Unión como principios generales”.

7. De modo que, a la vista de textos tan expresivos, y prescindiendo ahora de otras respuestas, nos encontramos a simple vista con un muy rico panorama en materia de derechos fundamentales, aunque también se vislumbre que la aplicación haya de ser compleja. Hay, ante todo, un expreso reconocimiento de la Carta $^{14}$ - con su triple orden de contenidos: "derechos", "libertades" y "principios"-, pasando a convertirse en texto jurídicamente vinculante, de la que se predica además que "tendrá el mismo valor jurídico que los Tratados". Aparece, en segundo lugar, la oportunidad para la Unión de adherirse al $\mathrm{CEDH}$, en cuyo caso éste le será plenamente aplicable, en los términos en que se concrete la adhesión. Se afianza, en tercer lugar, otra vía distinta, ya existente con antelación, dado que, aún cuando no se haya formalizado la señalada adhesión al CEDH, el contenido de éste, así como las tradiciones constitucionales a los Estados miembros, pueden servir de origen y de soporte a principios generales del derecho, que pasarán a formar parte del ordenamiento comunitario, como ya viene interpretando desde hace tiempo una

13 Desaparecida la "Comunidad", como se acaba de reflejar, en puridad parece que no sea ya exacto usar el adjetivo "comunitario" - para el Derecho o el ordenamiento-, no obstante, si se tienen las cosas claras, creo no hay obstáculos serios para seguir utilizando término de tanto arraigo a la par que tan expresivo.

14 Me parece oportuno explicar que mi interés por la respuesta que los derechos humanos recibían en Europa, que me había hecho fijarme con reiteración en la fórmula del Convenio Europeo de Derechos Humanos, en su Tribunal y en su jurisprudencia, se avivó desde que apareció en el panorama el empeño por lograr una declaración de derechos propia del sistema comunitario. Así, he seguido muy de cerca tanto la elaboración de la Carta, como sus pasos ulteriores, señaladamente el proyecto de Constitución Europea y, luego, la confirmación por el Tratado de Lisboa. A ello he dedicado numerosos cursos y conferencias y no pocas páginas, de alguna de las cuales se irá dando cuenta. En concreto, la plena consagración de la Carta que representa la entrada en vigor del Tratado de Lisboa, me ha llevado en los últimos meses a hablar específicamente de ello en diversas Facultades de Derecho, como las de Lérida, Orense y Santander, así como en lo equivalente al curso de doctorado en mi Facultad Complutense, en la que también fue expuesta como ponencia en la sesión inaugural de curso en el Seminario del profesor García de Enterría, en octubre de 2010. En la primavera del mismo año había emitido en la página web del Colegio Libre de Eméritos, al que me honro en pertenecer, tres lecciones sobre el mismo tema, que alcanzaron una cierta difusión y que son antecedente claro del texto que ahora se ofrece. Me agrada especialmente esta metodología que bien podría describirse con la expresión en lengua inglesa de "work in progress", y que probablemente culminará con la edición de un libro específico. 
rica y certera jurisprudencia del TJUE, que actuó como pionera para el reconocimiento de los derechos fundamentales en el ámbito comunitario.

8. Tal sería el punto de llegada, cuajado de incitaciones y oportunidades. Seduce reflexionar acerca de cómo algo a lo que nuestra sociedad le reconoce tanto predicamento, como los derechos fundamentales, adquiere tamaña importancia en lo que en origen fue una organización con mera vocación económica y comercial, una organización para asegurar el libre comercio, para garantizar la libertad de circulación, de desplazamiento y de instalación, y para afianzar en suma un mercado común. ¿¿Son necesarios aquí los derechos fundamentales? ¿Qué papel habrán de jugar? Estamos sin duda ante un consistente punto de llegada, cuyo contenido y alcance conviene fijar, pero para mejor valorarlo y entenderlo será oportuno estudiar cómo se ha llegado a él. Si bien, antes de precisar los pasos históricos más destacables que han conducido al ingente potenciamiento, en cuanto a contenidos y en cuanto a los Estados afectados, de lo que hoy llamamos la UE, así como a la legítima aspiración a lograr un concluyente elenco de derechos fundamentales que presida todo el sistema, convendrá hacer referencia, bien que somera, a algunos aspectos elementales para mejor comprender el alcance jurídico de la regulación de los derechos fundamentales.

III. A MODO DE INCISO: LA FACETA DE LO SIMBÓLICO Y LA DE LA OPERATIVIDAD JURÍDICA EN RELACIÓN CON LOS DERECHOS
FUNDAMENTALES

9. Parece conveniente, al tratar de los derechos fundamentales, parar mientes en lo que significan las dos facetas señaladas, tan diversas pero ambas necesarias y, de hecho, complementarias. Los derechos humanos se reconocen para resolver los problemas cotidianos y presidir así la convivencia. De ahí que importe mucho el aspecto de lo simbólico, lo que llega a la gente $^{15}$, aunque sea de manera un tanto simplificada, lo que suscita esperanzas, lo que preocupa y

\footnotetext{
15 Para ponderar el alcance de lo simbólico, recuérdese la Declaración número 52, aneja al Tratado de Lisboa, que se ha reproducido antes en la nota 5.
} 
entusiasma a la población, lo que es importante, por eso, que sea conocido y admirado, y defendido. En esta línea, han jugado un papel muy importante ese instrumento tan simple y sencillo como son las "declaraciones de derechos": suma breve, concisa, muy medida y concentrada, expresada con rigor y elegancia, fácilmente memorizable y presente, por tanto, en el imaginario colectivo. Se trata así de un instrumento de fácil proyección, con vocación de trascender las propias fronteras y llegar a provocar la emulación exterior. Al margen de importantes documentos de la antigüedad ${ }^{16}$, se puede recordar así, a modo de ejemplo, el importante papel desempeñado por la Declaración de Derechos del Hombre y del Ciudadano, temprana obra de la Revolución Francesa, de 26 de agosto de 1789 (aplicable hoy en Francia, formando parte del "bloque de la constitucionalidad) y, aún antes, la famosa Declaración de Derechos del Buen Pueblo de Virginia, de 12 de junio de 1776, justo en el momento de la ruptura con la metrópoli de las antiguas colonias británicas en América del Norte, siendo especialmente destacable, por llegar ya a nuestro tiempo, la Declaración Universal de Derechos Humanos (DUDH) que hicieron las Naciones Unidas en 1948, de la que enseguida se hablará, y que incorpora además un dato considerado hoy relevante, cual es el del carácter internacional del instrumento. Frente al localismo tan arraigado entre nosotros, pesa mucho -hay que recalcarlo con energía- el que las grandes declaraciones y proclamaciones de derechos sean instrumentos internacionales con vocación de muy extensa aplicación. Breves instrumentos todos ellos, cuidadosamente redactados, desde la idea de que, aparte de lograr sus objetivos, calaran en la población. Sin que sea de despreciar la idea de que hoy, de las declaraciones de derechos, al igual que ha sucedido con las Constituciones de los Estados, se va a proclamar su fuerza jurídicamente vinculante, afirmándose su carácter de norma, pero norma especialmente reforzada.

10. Es decir, que si importa lo simbólico, no basta con ello y hoy se asume con normalidad que deben existir cauces jurídicos operativos que puedan tornar reales las proclamaciones de cada declaración. Bien se afirma esta idea cuando la jurisprudencia del Tribunal de Estrasburgo (el Tribunal Europeo de Derechos Humanos, o, TEDH), proclama

16 Entre los que es de justicia recordar lo que han significado en el Reino Unido -ejemplo vivo para el resto del mundo civilizado-, la famosa Carta Magna, que los nobles hicieron otorgar al Rey "Juan Sin Tierra” en 1215, así como el "Bill of Rights", de 13 de febrero de 1689, considerados todavía hoy como formando parte del acervo constitucional británico.. 
reiteradamente que los derechos y libertades que contempla el Convenio Europeo de Derechos Humanos (CEDH ), del que aquel es el garante, no son aspiraciones ilusorias e hipotéticas sino que están llamadas a ser reales y efectivas. Es la idea de la efectiva operatividad, que va a reclamar a su servicio las respuestas jurídicas necesarias para que los derechos fundamentales dejen de ser meras proclamaciones y se proyecten de manera inequívoca sobre la realidad. Idea que se expresa de otra manera desde que la DUDH, de 1948, proclamó en su artículo 8 que "toda persona tiene derecho a un recurso efectivo ante los tribunales nacionales competentes, que la amparen contra actos que violen sus derechos fundamentales". Desde entonces, la idea del "recurso judicial efectivo", ha pasado a ser connatural al concepto de derechos fundamentales: entiendo que no se puede decir que exista un derecho fundamental si quien se ha visto perturbado en su goce y disfrute no puede acudir ante un juez imparcial e independiente en solicitud de protección.

Pues bien, ambos aspectos, han jugado, como veremos, un importante papel en la evolución de los derechos fundamentales en lo que hoy llamamos UE.

\section{IV. ¿A QUE SE COMPROMETEN LOS ESTADOS EN RELACIÓN} CON LOS DERECHOS FUNDAMENTALES?

11. Para mejor entender la evolución de los derechos fundamentales en el ámbito de la UE, será oportuno dedicar también breves minutos al interrogante que se ha formulado, así como, luego, a la pregunta de si hay momentos históricamente adecuados para que surjan las declaraciones de derechos. Comencemos por lo primero.

Habitualmente, se contemplan los derechos fundamentales desde la perspectiva de los ciudadanos: cuáles son las libertades incluidas, cuáles sus opciones, que manera hay de garantizar el respeto por parte de los poderes públicos, si surgen pretensiones jurídicas y derechos subjetivos, cómo funcionan los sistemas de garantías, adecuación de la tutela judicial, etc. Lo anterior implica que los derechos fundamentales surgen para embridar, contener y comprometer al Estado o, dicho más genéricamente, a los poderes públicos. Estos tienen que soportar, por poner algunos 
ejemplos, que cualquiera publique -o haga públicos- sus pensamientos o sus ideas sin interferencias (libertad de expresión), o que se creen partidos políticos (libertad de acción política y de asociación), que se practiquen las diversas religiones -y no sólo una religión oficial del Estado- o ninguna (libertad de pensamiento, de conciencia y de religión), tienen que sostener escuelas -para que se logre el derecho de todos a la instrucción-, del mismo modo que tienen que sostener centros sanitarios, para que así se haga realidad el derecho a la protección de la salud, o, por último, tienen que adoptar numerosísimas medidas para que resulte efectivo el derecho a la protección del medio ambiente. Unos y otros van a tener muy diverso alcance, bien diferentes repercusiones y van a comprometer al Estado de muy diversa manera. Por ejemplo, las libertades clásicas -como la libertad de expresión, libertad religiosa, libertad de reunión y de asociación y sus derivados, libertad de crear partidos políticos y sindicatos- han chocado brutalmente en cada caso con la mentalidad anteriormente dominante (monarquías absolutas, Estados totalitarios, etc.), pero una vez que se asume que hay que apostar por las libertades -recuérdese el ejemplo de la "Transición Política” en España, tras la muerte de Franco-, una vez que se superan los recelos ${ }^{17}$ y hábitos, podríamos decir que, en principio -y recalco lo de en principio, pues luego hay que hacer muchas reservas- no le costarían nada al Estado: se trataría del tradicional "laissez faire", "dejar hacer”. Serían, por así decir, derechos "baratos”, asumibles económicamente. En cambio, los que se suelen llamar "derechos sociales", en principio consisten en "prestaciones", y, dicho en dos palabras, cuestan dinero. ¿Cuánto dinero? No hay que ocultar que vivimos en tiempos en que nadie se contentaría con las libertades tradicionales -siempre imprescindibles, por supuesto-, y que hoy cualquiera, en nuestro entorno, considera normal que los poderes públicos se responsabilicen de un amplio elenco de derechos sociales. Lo que implica que, obviamente, habrán de hacer cuantiosas provisiones de fondo a la hora de preparar sus respectivos presupuestos. Es decir, que tienen que cuidar las cuentas. Y esto, hará que más de uno se lo piense. Lo que significa, y bien lo acredita la actual situación de crisis en algunos países, que llegar a ser un buen estadista no es sólo cuestión de introducir muchos derechos fundamentales, sino especialmente de saber allegar los medios para sostenerlos. Hay que tener muy claras las aspiraciones y exigencias, y darse arte para lograr los medios financieros necesarios, lo que vale,

\footnotetext{
17 Hemos de ver más adelante, como a la hora de dar vigencia plena a la Carta, algún Estado muestra sus reticencias ante concepciones que el mundo moderno considera hoy normales y auspiciables.
} 
obviamente, no sólo para el sistema de derechos fundamentales sino para toda la organización del Estado. El desconocimiento de regla tan elemental puede conducir a grandes desengaños, aparte de gravar a las generaciones futuras.

12. Por otro lado, dejar hacer - una vez que se asume- es fácil e, incluso grato. Lo mismo que dar o recibir prestaciones. Pero a veces, hay derechos que reclaman inexorablemente imponer numerosas prohibiciones. Y prohibir, ya es inoportuno. Pero a la vez, al mismo tiempo que se prohíbe, hay que inspeccionar $y$, eventualmente, sancionar $y$, con frecuencia, hay que exigir procedimientos, formas de actuar e instalaciones, que pueden resultar costosas (con las obvias repercusiones, a la hora de ganar menos, o de enfrentarse con la competencia). Sin que sea extraño que los propios poderes públicos tengan que financiar por sí mismos. Todo esto último vale directamente para una aspiración tan sentida en nuestro tiempo como es el derecho al medio ambiente: significativas prohibiciones - por ejemplo, no se puede verter lo que toda la vida se ha vertido al mar, a los ríos o, aunque sólo sea, al sumidero de la cocina de casa- y vigilancia, pero encarecimiento de los procesos, cuando no necesidad de cuantiosas subvenciones por parte de los poderes públicos. De ahí que sea normal que éstos tengan interés en saber a qué se comprometen con cada nuevo derecho, es decir, cuantificar cuanto les va a costar, aunque sea aproximadamente, pues obviamente una de las reglas de juego asumidas en los Estados modernos, es la de que los poderes públicos tienen que atenerse a unos presupuestos, debidamente aprobados, y en los que haya un razonable equilibrio entre ingresos y gastos. Magnitudes que no son elásticas ni estirables según los gustos o caprichos, sino limitadas, muy limitadas, como bien se comprueba en nuestros días, al margen de falsas ilusiones.

13. En la evolución, a la hora de codificar en unos u otros términos derechos fundamentales en la UE, va a influir además de manera determinante una de las características que antes se anotaba: la de la auspiciable y necesaria intervención judicial a la hora de garantizarlos: ¿Qué pueden hacer los jueces? O, sobre todo, ¿en que medida y a cuanto pueden condenar al Estado? Decir si es correcta o incorrecta una intervención que incida en la libertad de cátedra, o en la libertad de reunión -por centrarnos en ambos ejemplos- ofrecería un panorama de respuestas judiciales limitado y, sobre todo, cognoscible de ante mano. Es decir, que permite saber 
a que atenerse. En relación, en cambio, con el derecho a la protección de la salud, ¿a qué puede condenar el juez? ¿Puede -por ponerse un ejemplo exagerado, pero no ilusorio- imponer ante la solicitud de un enfermo un costoso tratamiento en la clínica más especializada de cualquier lugar del mundo? Aquí aparece, por decirlo en dos palabras, el temor -diría incluso, el pavor- que sienten algunos Estados serios a lo que podemos denominar el "activismo judicial”. Hay Estados previsores y responsables, bien respetuosos de sus obligaciones, que antes de dar un paso quieren saber minuciosamente a qué se comprometen. Y, recalco, aparecerá la decidida intención de que los jueces, al garantizar y supervisar, tengan claramente predeterminado su marco de actuación, es decir, que no puedan salirse ni "inventar", muy presente el temor -históricamente comprobadoal activismo judicial. Pues bien, hemos de ver como estas ideas han pesado de manera determinante cuando se han intentado codificar los derechos fundamentales en la UE, actuando a veces como elemento retardatario o, auspiciando la introducción de modalidades, distingos y reservas. Y que, además, desde el punto de vista de la naturaleza de los derechos, se traducirá en la distinta densidad jurídica de los correspondientes preceptos.

\section{V. ¿HAY UNOS TIEMPOS PROPICIOS PARA LAS DECLARACIONES DE DERECHOS?}

14. Las reflexiones anteriores llevan a la conclusión de lo arduo y complejo que resulta en la mayor parte de los casos lograr una declaración de derechos a la altura de las exigencias. Con frecuencia, las declaraciones de derechos son un auténtico revulsivo, desde el afán de superar la situación real existente con anterioridad. De ahí que si se quiere hacer una declaración de derechos que resulte efectiva, que sea de amplios contenidos, que atienda a las aspiraciones sociales del momento histórico y, sobre todo, que aspire a comprometer a organizaciones internacionales y a una pluralidad de Estados, puede resultar muy ardua tarea, dadas las distintas sensibilidades y compromisos, a la vista también de la diferencia de recursos económicos entre los diversos socios comprometidos. Hay muchas formas de actuar y muchas opciones a conseguir, pero sin duda, la experiencia histórica enseña que hay unos momentos especialmente propicios para que puedan cuajar las declaraciones de derechos. Se habló de la Declaración de Derechos del 
Buen Pueblo de Virginia, que surge en el momento preciso en que las "trece colonias" de América del Norte se independizan de la metrópoli británica y pasan a considerarse Estados independientes. Recordaba también la Declaración francesa de 1789. Sorprende con que rapidez, los revolucionarios franceses urgidos por tantas tareas, logran consolidar en tan poco tiempo desde el inicio de la Revolución texto tan importante: y es que sin duda se trataba de momento propicio para semejante innovación. Del mismo modo que no nos extrańa, por traer un ejemplo de España, que en el significativo momento constituyente, presidido entre otras cosas por la nota del consenso, se lograra la tan completa y tan innovadora declaración de derechos que incluye el Título I de la Constitución Española de 1978.

También en relación con el sistema comunitario vamos a poder observar que juega un gran papel el momento elegido para codificar los derechos. Lo veremos sin duda en cuanto a la elaboración de la Carta de Derechos Fundamentales que, tras una serie de avatares, se convertiría en nuestro punto de llegada, como antes se indicó, pero la observación es todavía más incisiva en cuanto al punto de partida. Y es que creo firmemente que el punto de partida de la actual organización europea hay que situarlo, sin falta, en la gran crisis espiritual que se produce al término de la Segunda Guerra Mundial. La desolación sentida en aquel momento, la generalizada experiencia de muerte y destrucción, la constatación del desastre a que habían conducido los Estados totalitarios que provocaron, iniciaron y animaron la Guerra, toda una serie de circunstancias negativas, provocaron muy nobles y certeras reacciones, cuyas secuelas nos ha tocado vivir. Por de pronto, hay un sentimiento generalizado de que, para que no se repitan los errores denostados, los Estados tienen que comprometerse inexcusablemente a respetar un conjunto de exigentes derechos fundamentales ${ }^{18}$. Es así como insiste sobre los derechos fundamentales la Carta de las Naciones Unidas, redactada en San Francisco en el verano de 1945, y cómo la propia organización logra tres años más tarde el importante documento constituido por la Declaración Universal de Derechos Humanos, aprobada por la Asamblea General, reunida en París, el 10 de diciembre de 1948. Y si esto son pasos de carácter mundial, no menos interesante

18 De destacar así el significado de la "doctrina de la cuatro libertades", auspiciada por el Presidente estadounidense F. D. Roosevelt en su mensaje de 6 de enero de 1941: libertad de palabra y expresión, libertad de conciencia, la liberación de la miseria y la liberación del miedo. Es reconocido unánimemente el influjo que tuvo en la DUDH. 
será la reacción que se produce a nivel europeo ${ }^{19}$, que se bifurcará, además, claramente, en una doble dirección bien diferenciada inicialmente.

\section{REACCIÓN EUROPEA FRENTE A LOS DESASTRES DE LA}

\section{GUERRA: UNA DOBLE DIRECCIÓN}

15. La profunda crisis espiritual a que me refería no podía por menos de provocar también notables reacciones en el ámbito europeo. Que, como digo, van a caminar en dos direcciones próximas, pero bien diferentes. De destacar así que tempranamente -y arrancando de bien nobles precedentes $^{20}$ - ha de cobrar señalada importancia el movimiento a favor de los derechos fundamentales. Una de las respuestas del momento es la creación del Consejo de Europa, cuyo Estatuto se firma en Londres, el 5 de mayo de 1949. Y una de sus más tempranas actividades consiste en la elaboración de una pieza maestra en el campo de los derechos fundamentales: desde la idea de hacer efectivos cuanto antes en Europa los más granados derechos y libertades de la DUDH, se elabora y se firma en Roma, el 4 de noviembre de 1950, el Convenio Europeo para la Protección de los Derechos Fundamentales y Libertades Públicas. Es así como surge el llamado "sistema de Estrasburgo", que a una viva declaración de derechos -trasunto de la DUDH- añade el inestimable logro, tan sorprendente en aquella época, de erigir un Tribunal para asegurar el cumplimiento efectivo de los derechos garantizados, un Tribunal cuya definitiva misión consistía en condenar a los Estados que violaran los derechos fundamentales ${ }^{21}$. Ese sistema creció y se desarrolló y hoy goza de extraordinaria salud. El texto originario del Convenio se va completando

19 Por ceñirnos a nuestro espacio geográfico. Pero es importante tener en cuenta el gran significado que alcanza también la evolución producida en el ámbito americano, de la que constituye un hito notabilísimo, por ceñirme a un único ejemplo, la Convención Americana de Derechos Humanos, firmada en San José de Costa Rica el 22 de noviembre de 1969. Véase Antonio TRUYOL SERRA, Los derechos humanos, 74 ss.

20 Bien expresivo resulta, por ejemplo, el "Proyecto de Declaración de las Resistencias Europeas", firmado "en una ciudad europea” en plena guerra -julio de 1944-, donde, al tiempo que se auspicia para Europa una "Unión Federal", se remacha: "La Unión Federal deberá estar fundada sobre una Declaración de los Derechos civiles, políticos y económicos que garantice el libre desarrollo de la personalidad humana y el funcionamiento normal de las Constituciones democráticas; además deberá apoyarse en una Declaración de los derechos de las minorías a una existencia autónoma que sea compatible con la integridad de los Estados nacionales de los cuales forman parte". Véase, Antonio TRUYOL SERRA, La integración europea, pág. 160.

21 Según ha contado su albacea, el profesor García de Enterría, la idea de erigir un Tribunal que actuara de garante, fue defendida por Don Salvador de Madariaga, que jugó un papel muy activo en la fase preparatoria del Consejo de Europa. 
periódicamente a través de "protocolos adicionales". Lo mismo ha sucedido con los países incluidos en el sistema: arrancando de los diez que originariamente integraban el Consejo de Europa, hoy se hallan sometidos a la jurisdicción del Tribunal Europeo de Derechos Humanos los 47 Estados que actualmente integran el Consejo, incluyendo una población de más de 800 millones de personas. Su jurisprudencia goza de merecido prestigio y es notable la fuerza que ha tenido para erradicar tantas prácticas viciadas, actuando de guardián incansable de los derechos fundamentales en esta Europa ampliada que constituye el Consejo de Europa. Con la particularidad, que debe ser especialmente destacada, de que todos y cada uno de los 27 Estados que hoy integran la Unión Europea han aceptado someterse al CEDH y acatan expresamente la jurisdicción del Tribunal Europeo de Derechos Humanos. Sin que sea de olvidar que la propia organización comunitaria ha marcado una línea titubeante de aproximación al Convenio Europeo de Derechos Humanos, como se ha de estudiar algo más adelante. De momento, ahí queda esta importante línea de afirmación europea de los derechos fundamentales, sobre la que más adelante habremos de volver.

16. Pero en ese periodo crítico se inicia también la marcha en otra dirección, que es la que a nosotros va a interesarnos de manera más directa. No es sólo la desolación observable al concluir la Guerra, es de forma especial la constatación del enfrentamiento intermitente y periódico entre Francia y Alemania: en 1870 termina con la batalla de Sedán la Guerra Franco-Prusiana; a los treinta y tantos años después, otro nuevo enfrentamiento, que parecía el no va más en cuanto a los medios de destrucción -aviones, tanques, etc.-, la "Gran Guerra" (1914-1918); y apenas 20 años después, la gran catástrofe de la Segunda Guerra Mundial (1939-1945). Es así como las mentes más lúcidas -y ahí estará el origen de la organización comunitaria- van a caer en la cuenta de que es preciso atajar ante todo la confrontación económica que venía presidiendo las relaciones entre Alemania y Francia, que, de hecho, venía corroyendo la convivencia. De esta manera, esas mentes lúcidas y clarividentes (Monet, Schuman, etc.) se conciertan para poner en marcha mecanismos de integración económica y comercial. Surgirá así en 1951 la Comunidad Europea del Carbón y del Acero -la CECA-, y al fructificar el ensayo, se irán intensificando las opciones integradoras. 1957 será un momento decisivo en ese proceso: se creará así la Comunidad Europea de la Energía Atómica -EURATOM- y, sobre todo, la Comunidad Económica Europea (Tratado de Roma, 
Constitutivo de la Comunidad Económica Europea, de 25 de marzo de 1957), la que luego se denominaría el Mercado Común y que ha pasado a ser la actual Unión Europea ${ }^{22}$. Esta segunda línea de integración europea resultaría decisiva, complementaria a la línea especializada en la afirmación de los derechos fundamentales. Pero ello significa que esta segunda línea se especializa en lo comercial y en lo económico. Aparentemente no tiene por qué ocuparse de los derechos fundamentales. Lo que sucede es que la CEE va a conocer también un notable proceso de ampliación, en cuanto a sus fines y cometidos, pero también en cuanto a su extensión territorial, pasando de los seis Estados iniciales a los 27 actuales. Y es así como, a consecuencia de esta evolución, y por una serie de razones importantes, se irá echando en falta la presencia de los derechos fundamentales en el ordenamiento comunitario, y se irán dando significativos pasos al respecto. Lo que nos deja en puertas de una significativa evolución que pasamos a estudiar seguidamente.

VII. ESTADO DE LA CUESTIÓN: LA APUESTA POR LA ALTERNATIVA ECONÓMICA. PERO HAY DERECHOS FUNDAMENTALES QUE JUEGAN UN IMPORTANTE PAPEL EN UNA ORGANIZACIÓN ECONÓMICA

17. Las dos líneas que se señalaron seguirían su camino. En el ordenamiento jurídico del Consejo de Europa -en el que se contemplan tan variados aspectos interesantes- halla lugar muy cualificado la garantía de los derechos humanos, a través del sistema del Convenio Europeo de Derechos Humanos, con el protagonismo cualificado del Tribunal Europeo de Derechos Humanos (y también, al comienzo, hasta su desaparición el 1 de noviembre de 1988, de la Comisión Europea de Derechos Humanos). Un sistema, como se señaló, abierto y en progresión: con el tiempo, irán aumentando los Estrados comprometidos a través de nuevas adhesiones, se amplían los derechos garantizados, mediante la incorporación de "protocolos adicionales", siendo de destacar también que la propia jurisprudencia del Tribunal se caracteriza por una marcada

\footnotetext{
22 Recuérdese la frase final del artículo 1 del TUE en su nueva redacción, que antes se reprodujo, en el sentido de que, "La Unión sustituirá y sucederá a la Comunidad europea.
} 
línea expansiva, abriendo incesantemente nuevas oportunidades mediante una interpretación ampliatoria del Convenio, que busca potenciar las opciones de los derechos y libertades consagrados.

En la otra dirección, las tres Comunidades - "Carbón y Acero”, "Energía Atómica”, así como la por antonomasia "Comunidad Económica”, en la que me voy a fijar especialmente- irán arraigando y afianzándose en sus funciones y cometidos. Cada una de ellas tendría un éxito innegable, debiendo destacarse, en una visión de conjunto -prescindiendo de dificultades o, incluso, de pasos en falso, cómo la CEE se asienta con energía y va potenciando sus aspiraciones y funciones, que darán lugar a un avance imparable. Y, simplificando también, periódicamente se irá ajustando el marco jurídico, ya sea a través de la modificación del originario Tratado Constitutivo, ya sea añadiendo alguna otra pieza importante -como el Tratado de la Unión, a raíz de la reforma de Maastricht de 1992-, siendo de notar también la gradual incorporación al sistema de nuevos Estados miembros ${ }^{23}$.

18. La especialización económica y comercial señalada justificaría que a ellas se dedicaran las mayores energías, siendo de destacar los ingentes esfuerzos dedicados al afianzamiento de las famosas cuatro libertades que caracterizan el empeño comunitario: la libre circulación de mercancías, de personas, de servicios y de capitales (reflejadas en el actual ordenamiento jurídico comunitario, en los Títulos II y IV de la Tercera Parte del TFUE). Al margen de dicho empeño tan decisivo y que tantos esfuerzos ha ido exigiendo a lo lago del duradero proceso de afirmación y afianzamiento-, señalan unánimemente los estudiosos que, desde el punto de vista de una respuesta ad hoc a la problemática específica de los derechos fundamentales (en adelante, DDFF), apenas se encontraba una única referencia en el ordenamiento comunitario. Sería la mención que hoy recoge todavía literalmente -pero en un contexto ya muy diverso- el artículo 157.1 del actual TFUE, y que atañe a algo tan vinculado al sistema económico, como es la cuestión salarial, pero donde se introdujo una preocupación, muy presente siempre en el sistema comunitario -y a la

23 Para un planteamiento de conjunto, véase, por todos, Ricardo ALONSO GARCÍA, Derecho Comunitario. Sistema Constitucional y Administrativo de la Unión Europea, reciente segunda edición de 2010, así como Luis MARTÍN REBOLLO, Estudio Preliminar, a su Código de la Unión Europea, y Estudio Preliminar sobre los Tratado, el Derecho y las instituciones europeas, en sus Leyes Administrativas, 271-318. 
que hoy se le sigue dedicando señalada importancia- como es la de la no discriminación por razón del sexo. Pionera, y con presencia destacada, por ende, la regla de la no discriminación salarial por razón del sexo. La vieja fórmula, mantenida incólume, señalaba:

"Cada Estado miembro garantizará la aplicación del principio de igualdad de retribución entre trabajadores y trabajadoras para un mismo trabajo o para un trabajo de igual valor" (TFUE 157.1)

He aquí cómo, al abordar aspectos tan estrictamente económicos, como los referentes a los salarios, en un título IX dedicado al "Empleo", se "cuela" regla tan decisiva en la teoría de los derechos fundamentales. Y tiene su lógica, pues los DDFF no son algo a conservar en una campana neumática sino que, por definición, tienen vocación de penetrar en los más mínimos resquicios de la vida cotidiana. Pero lo cierto es que el Derecho comunitario no abordaba un planteamiento global de los $\mathrm{DDFF}^{24}$. Y, sin embargo, en puridad, esa falta de respuesta y de previsión no podía durar. Y es que aún en el más espeso núcleo de lo económico y comercial siempre hay unos derechos fundamentales que pueden resultar muy útiles, muy funcionales incluso, por lo que es normal que terminen siendo afirmados y reconocidos. Se hablaba de la no discriminación salarial, pero no se puede desconocer al propio tiempo el papel que juegan, por ejemplo, entre otros, el derecho de propiedad, el derecho a la libertad de empresa, los derechos de los consumidores, el derecho a la protección del domicilio, incluida la sede social de las empresas, o la libertad de expresión. Todos ellos, y muchos más, resultan sumamente convenientes a la funcionalidad de un sistema económico.

19. Hay también otra circunstancia a considerar sin falta, y tiene que ver con el efecto de potenciamiento de lo comunitario, la ampliación de fines y funciones, así como los instrumentos jurídicos que se van perfilando a su servicio. Porque, a partir de un determinado momento, se irá construyendo judicialmente la regla de que el Derecho comunitario desplaza a los derechos

\footnotetext{
24 Para esta visión introductoria, me remito al excelente trabajo de Ricardo ALONSO GARCÍA, Derechos fundamentales y Comunidades Europeas. Véase también, Juan Antonio CARRILLO SALCEDO, La protección de los derechos humanos en las Comunidades Europeas, y Lorenzo MARTÍN-RETORTILLO, Para una afirmación de los derechos fundamentales en la Unión Europea.
} 
nacionales así como, en concreto, la regla de la primacía del Derecho comunitario ${ }^{25}$. Es decir, en caso de fricción entre la solución jurídica que ofrezca el derecho de un Estado y la solución comunitaria, ésta desplaza a aquella y debe quedar, por tanto, enervada. Acaso, la fórmula no chocaría de manera excesiva en aspectos triviales del derecho económico y del de la regulación comercial. Pero hay un momento en que surge el interrogante: ¿y si el Derecho comunitario fuerza a desconocer garantías consagradas por el sistema constitucional de uno de los Estados? ¿Habrá también que abandonarlas para reconocer que prime el Derecho comunitario? Como se recordará, cuestiones tales fueron planteadas, en un momento determinado, de forma un tanto ácida por los Tribunales Constitucionales de Italia y de Alemania ${ }^{26}$.

En definitiva, que se piense lo que se piense, no era realista una situación de ausencia de respuesta ante las tensiones referentes a derechos fundamentales que pueden aparecer en los más inesperados espacios de un sistema social mínimamente desarrollado. Ante todo, por la necesidad de ofrecer una solución a los conflictos que se iban suscitando de la forma más inesperada, fenómeno que, sin embargo, bien se podía haber adivinado con sólo dedicar tiempo a las oportunas previsiones. Pero en el fondo había de pesar también el argumento del prestigio y de las apariencias: a las numerosas bazas manejadas por los "euroescépticos" -o "eurocríticos"-, como la de falta de legitimación democrática de los órganos comunitarios, la de la burocratización y falta de transparencia en la toma de decisiones, no se podía añadir, servida en bandeja, la del desconocimiento de los DDFF, en momentos, además, de tanta sensibilidad hacia ellos, como se describía al inicio. Es decir, que no tenía justificación la situación de carencia. Bien conscientes, eso sí de que, como se explicó, más allá de las legítimas aspiraciones, a la hora de la verdad, es bien complejo poner de acuerdo a tantos y tan diversos Estados en materia de DDFF, sobrevolando siempre la idea de lo que supondrá cada uno de los compromisos que se adopten.

\footnotetext{
25 Véase, por todos, Ricardo ALONSO GARCÍA, Derecho Comunitario y Derechos Nacionales. Autonomia, integración e interacción, págs. 155 y sigs., y Lorenzo MARTÍN-RETORTILLO, La interconexión de los ordenamientos jurídicos y el sistema de fuentes del derecho, 173 y sigs.

26 Se trata del importante episodio conocido habitualmente -dado el planteamiento alemán- como “jurisprudencia Solange”. Véase, por todos, José María BAÑO LEÓN, Los derechos fundamentales en la Comunidad Europea y la Competencia del juez nacional; Ricardo ALONSO GARCÍA, Derechos fundamentales y comunidades Europeas, pás. 804 y sigs., y, últimamente, Araceli MANGAS MARTÍN, Introducción, al volumen por ella dirigido, Carta de los Derechos Fundamentales de la Unión Europea. Comentario articulo por artículo, págs. 37 y sigs.
} 


\section{LOS DERECHOS FUNDAMENTALES COMIENZAN A}

\section{PREOCUPAR}

20. De hecho, lo cierto es que pronto surgiría la preocupación y el convencimiento de la necesidad de adecuar respuestas, unas u otras, puesto que irían apareciendo una pluralidad de intentos de solución, unos más afortunados que otros, alguno, de efecto inmediato, mientras otros necesitaban largos tiempos de maduración.

Uno de los timbres de gloria de la evolución del Conseil d'Etat francés -y de otros prestigiosos tribunales- ha consistido en la utilización del método "principialista": en ausencia de norma expresa para solventar un conflicto, y ante el habitual caos del ordenamiento administrativo, podía dar resultado la extracción del conjunto, de principios generales del derecho. Es así como éstos -buena fe, igualdad, proporcionalidad, etc.-, en una larga y ejemplar evolución, le habrían servido al Consejo de Estado para dar solución legítima -y un tanto espectacular- a tantos conflictos planteados. Pues bien, como ha sido reiteradamente destacado, es mérito cualificado del Tribunal de Justicia el que se diera arte para extraer de las "tradiciones constitucionales a los Estados miembros", principios generales del derecho, con los que solventar los conflictos que iban apareciendo en el campo de los derechos fundamentales ${ }^{27}$. Hoy que, como ya nos consta, el ordenamiento jurídico comunitario incluye una consistente codificación en el campo de los derechos fundamentales, es de justicia reconocer que dicha fórmula de "las tradiciones constitucionales comunes a los Estados miembros", que luce de de manera expresa en los Tratados -recuérdese el artículo 6.3 TUE, que antes se transcribió, así como el párrafo 5 del Preámbulo de la Carta, del que más adelante nos ocuparemos-, es un claro reconocimiento de la labor pionera y adelantada realizada por el TJCE: sería un homenaje dirigido al mismo pero, a la par, un estímulo por si tuviera que volver a hacer uso de dicha metodología.

\footnotetext{
$27 \quad$ Valga de nuevo una remisión genérica al destacado trabajo de Ricardo ALONSO GARCÍA, Derechos fundamentales y Comunidades Europeas.
} 
En la vida y en la evolución de la CEE y luego UE, cuya estructura jurídica es una mezcla de soluciones de los más variados sistemas, y en la que, por ejemplo, y por simplificar, fórmulas del sistema de "commun law" conviven con opciones del sistema continental, ofrece gran interés la presencia de un corpus de principios generales del derecho alumbrados jurisprudencialmente ${ }^{28}$. Lo que no impide que se aprecie -o se eche en falta, en su caso- la presencia de fórmulas introducidas de forma expresa y reflexiva en el cuerpo de los Tratados.

En este sentido, hay que hacerse eco de un incesante afán por abordar de forma expresa y con vocación de generalidad las cuestiones más candentes en el ámbito de los derechos fundamentales. Con mayor o menor intensidad o fuerza, con mayor o menor amplitud, variando las aspiraciones y las direcciones a tomar, y con bien diversas iniciativas de unos u otros órganos comunitarios, hay una larga historia de pasos que han pretendido hacer llegar a los Tratados las soluciones oportunas, tal y como se pensaban en su momento. No es posible seguir ahora la totalidad de esos pasos con detenimiento ${ }^{29}$, pero sí aludiré a algunos cuantos momentos especialmente significativos, aunque acaso no pasaran del intento, o quedaran sólo en la vertiente de lo simbólico. Lo cierto es, con todo, que, vistas las cosas desde el punto de llegada, no pocos de esos intentos frustrados prepararon el terreno para los pasos ulteriores.

IX. LOS PASOS MÁS DESTACADOS DE UNA LARGA EVOLUCIÓN. EL PROYECTO SPINELLI DE UNIÓN EUROPEA (1984): UN AMBICIOSO PROGRAMA ABARCANDO MUCHOS FLANCOS

\footnotetext{
28 Es curioso constatar así, por ofrecer un ejemplo gráfico, como las "Explicaciones" a la Carta recuerdan que el artículo 41, referente al "derecho a una buena administración", tiene su origen en la labor jurisprudencial "que consagró, entre otras cosas, la buena administración como un principio general del derecho", enumerándose al respecto decisiones tanto del Tribunal de Justicia como del Tribunal de Primera Instancia.

${ }_{29}$ Resulta muy interesante al respecto el citado trabajo de Ricardo ALONSO GARCÍA, Derechos fundamentales y comunidades europeas, 810 y sigs., donde detalla minuciosamente la rica y zigzagueante serie de posturas y de iniciativas.
} 
21. Bueno será, a efectos de la síntesis que ahora interesa, comenzar esta exposición por un texto relevante -síntesis, como se ha señalado, de otras fórmulas y soluciones anteriores que llevaban mucho tiempo decantándose-, muy completo en el aspecto concreto que ahora interesa y que, como puede constatarse hoy a posteriori, marcó un auténtico programa cuyos pasos se irían alcanzando en sucesivas oleadas. Me refiero al tan rico y determinante documento conocido habitualmente como "Proyecto Spinelli de Unión Europea”, una resolución adoptada por el Parlamento Europeo el 14 de febrero de 1984, en la que éste, "en tanto que primera Asamblea directamente elegida por los ciudadanos europeos", invita al Parlamento Europeo que será elegido por los ciudadanos europeos el 17 de junio de 1984 a adoptar una serie de medidas, marcándole el guión al aprobar "el proyecto de Tratado que establece la Unión Europea”. Pues bien, en este texto no faltan en lugar destacado muy señaladas previsiones, que se incluyen en el artículo 4, bajo la rúbrica "Derechos Fundamentales" y que por su interés transcribiré íntegro en sus 4 apartados:

“1. La Unión protege la dignidad del individuo y reconoce a toda persona dependiente de su jurisdicción los derechos y libertades fundamentales, tales como derivan de los principios comunes de las constituciones de los Estados miembros, así como de la Convención Europea para salvaguardar los derechos del hombre y libertades fundamentales.

2. La Unión se compromete a mantener y a desarrollar, dentro de los límites de sus competencias, los derechos económicos, sociales y culturales que derivan de las constituciones de los Estados miembros, así como de la Carta social europea.

3. Dentro de un plazo de cinco años, la Unión deliberará sobre su adhesión a los instrumentos internacionales mencionados, a los Pactos de Las Naciones Unidas relativos a los derechos civiles y políticos, así como a los derechos económicos, sociales y culturales. Dentro del mismo plazo, la Unión adoptará su propia declaración sobre derechos fundamentales en base a un procedimiento de revisión previsto en el artículo 84 del presente Tratado. 
4, En caso de violación grave y persistente por parte de algún Estado miembro de los principios democráticos o de los derechos fundamentales, podrán adoptarse sanciones en base a las disposiciones del artículo 44 del presente Tratado”.

Insisto que creo se trata de propuesta de gran calado, con sugerencias del mayor interés. Valdrá la penas subrayar algunas de sus pretensiones más destacadas.

22. He aquí algunas consecuencias destacadas de tan señalado texto:

A). Diré ante todo que, como primera y más relevante consecuencia, se intenta llevar al texto de los Tratados el compromiso formal y solemne de la Unión con los DDFF.

B). ¿A qué se compromete la Unión? ¿Cuáles son los derechos fundamentales que se reconocen? Conviene notar que se marcan diversos caminos al respecto. Se va a hacer uso de una distinción de gran arraigo en la teoría de los derechos fundamentales, por más que en ocasiones pueda ofrecer contornos poco claros: se suele hablar de los derechos "políticos" y "cívicos", o "tradicionales", o "de primera generación", para contrastarlos con los derechos "económicos y sociales" Pues bien, en relación con aquéllos, se postula el reconocimiento de los que derivan de los principios comunes de las Constituciones de los Estados miembros, así como los del CEDH. Hay que destacar así, ante todo, la referencia al depósito de derechos fundamentales contenido en las Constituciones de los Estados miembros. Aun integrando el sistema comunitario un ordenamiento jurídico propio, se ha destacado la constante interrelación entre las reglas jurídicas de aquel y las de los ordenamientos nacionales. Es decir, que los derechos fundamentales de los Estados se erigen, según este párrafo, en basamento del sistema jurídico de la Unión. Recuérdense las reticencias a que antes me refería en el sentido del lamento de algunos Estados de que el Derecho comunitario pudiera prescindir de los derechos fundamentales garantizados por el sistema constitucional de los Estados, tan arduamente conseguidos algunos de ellos, y como antídoto para que nunca más volvieran a repetirse situaciones por todos lamentadas. En este testimonio de la "aspiración" de lo que se pretende alcanzar en materia de derechos 
fundamentales, se da el gran paso de asumir con normalidad que las Comunidades deben llegar al mismo nivel que han alcanzado los Estados.

Junto a las fórmulas nacionales aparece obviamente otra línea bien clara. Se ha hablado de cómo la especialización europea en materia de derechos fundamentales se representa de manera señalada en el CEDH, soporte del que denominamos "sistema de Estrasburgo", donde plasmó la especialización europea para garantizar los derechos fundamentales. Es lógico por eso que cuando se piense desde las Comunidades en "arreglar la partida" de los DDFF, se eche mano de lo que venía funcionando con acierto. Casi, como si no hubiera que innovar, bastando con "apoyarse o remitirse" a lo que ya ha sido construido y venía resultando eficaz.

C). Pero junto a las libertades tradicionales ha ido ganando base en la sociedad la aspiración a los llamados derechos económicos y sociales. También con ellos pretende comprometerse la Unión. De ahí la mención al otro texto especializado, la Carta Social Europea, elaborada también en el seno del Consejo de Europa, y aprobada en Turín el 18 de octubre de 1981, soporte de un amplio depósito de derechos sociales ${ }^{30}$. La idea es, de nuevo, que la Unión se sirva de un texto prestigioso, ya elaborado y operativo. Pero se aborda también el otro nivel: como los Estados miembros habían ido incorporando a sus Constituciones un paquete sustancioso de derechos sociales $^{31}$, para no defraudar, y para que no haya desniveles, con la misma metodología antes señalada, se afianza el compromiso de alcanzar el nivel ofrecido por las Constituciones de los Estados.

D). Se comienza señalando un compromiso por así decir programático que, a la par que cubrir la parcela de lo simbólico pretende orientar e incentivar, pero la construcción ofrecía con acierto un nuevo elemento complementario: la idea de que se realizara la adhesión expresa, con lo que el compromiso sería pleno y quedaría asegurada la más completa operatividad jurídica. Se marcaba así el plazo de cinco años para que la Unión "deliberara”, invitándole de esta forma a

$30 \quad$ En el Preámbulo de la Carta Social se explica que así como el CEDH pretendió garantizar los "derechos civiles y políticos", ahora se pretende insistir en los "derechos sociales".

31 Arrancando de la primera Constitución europea de la postguerra, la Francesa de 1946, confirmando decididamente la línea que en el periodo de entreguerras habían iniciado la Constitución mexicana de 1917, así como la alemana de Weimar, de 1919. 
preparar su compromiso jurídico. Compromiso que en la idea que se glosa era de una gran amplitud: la adhesión se refiere a los dos instrumentos mencionados -el CEDH y la Carta Social Europea- pero se quiere proyectar también a los dos relevantes instrumentos de Naciones Unidas que desarrollan la DUDH. Sin perjuicio del prestigio y de los efectos más o menos difusos que pueda proyectar tan cualificada declaración de derechos, sabido es cómo se buscó la forma de hacerla plenamente operativa desde el punto de vista jurídico para quienes optaran libremente por vincularse, a la par que se desarrollaban sus contenidos, mediante la promulgación de los dos "Pactos de Nueva York", ambos de 11 de diciembre de 1966, el Pacto Internacional de Derechos Civiles y Políticos, y el de Derechos Económicos, Sociales y Culturales ${ }^{32}$. Es decir, la idea del Proyecto Spinelli era la de que la Unión se comprometiera al máximo nivel entonces existente en cuanto a la garantía de los DDFF.

E). Hasta aquí, la idea de la remisión, haciendo propios los instrumentos por otros elaborados, en esa fórmula tan sugestiva y tan frecuente, por más que dificultosa, tan característica de nuestro tiempo, como es el fenómeno de la interconexión de los ordenamientos jurídicos ${ }^{33}$. Pero se daba un paso más, comprometido y delicado: se auspiciaba la elaboración por la Unión de su "propia declaración de derechos fundamentales". Idea que se lanzaba para que fuera rodando, pero dotada también de un plazo: el mismo de 5 años marcado para la adopción de los anteriores documentos. Había un pequeño matiz que el transcurso del tiempo ha hecho intrascendente pero que no quiero dejar de señalar: en relación con las declaraciones "ajenas", el plazo de 5 años era para "deliberar", pero en cambio, en relación con la declaración "propia”, la forma era más enérgica, ya que se hablaba de que "la Unión adoptará su propia declaración sobre derechos fundamentales".

32 De recordar que estas cuatro declaraciones de derechos, tan señaladas, fueron tempranamente ratificadas por España, como pasos notables de la "Transición Política": el CEDH, lo firmó España el 24 de noviembre de 1977, apenas elegidas las Cortes Constituyentes, y fue ratificado el 26 de septiembre de 1979; el Pacto de Derechos Civiles y Políticos fue ratificado el 13 de abril de 1977, y el 27 del mismo mes y año, el de Derechos Económicos, sociales y Culturales; la ratificación de la Carta Social Europea apareció en el "Boletín Oficial del Estado" de de 26 de junio de 1980; y, en cuanto a la DUDH, sabido es cómo la asume la propia CE, en su artículo 10.2

33 Me remito de nuevo a mi citado libro, La interconexión de los ordenamientos jurídicos. 
F). Si los derechos fundamentales habían de presidir el horizonte tanto de la Unión como de los Estados miembros, una pieza lógica del sistema había de ser la posible reacción para el caso de que uno de los Estados integrantes abdicara de su compromiso de respeto a los DDFF. A ello atendía de manera expresa el último de los apartados del precepto glosado.

\section{EL PEQUEÑO TESTIMONIO DEL ACTA ÚNICA EUROPEA} (1986)

23. En 1986 se da un paso muy señalado en la evolución de las Comunidades, con las novedades introducidas por el Tratado del Acta Única Europea. Se van a recibir algunas de las propuestas del Proyecto Spinelli, y al mismo tiempo que se plasma la idea de llegar desde las Comunidades Europeas a una Unión Europea, a la par que se insiste en la profundización de las políticas comunes en el campo de la economía, el pequeño "guiño" a los DDFF se manifiesta en este expresivo párrafo tercero del Preámbulo, bien gráfico, pero que, más allá de lo simbólico, a la hora de la verdad, quedó sólo en eso, un párrafo en el Preámbulo. Se entenderá mejor la afirmación si se recuerda que, según el encabezamiento del Tratado, los sujetos de la frase son los Jefes de Estado de los países signatarios:

"DECIDIDOS a promover conjuntamente la democracia, basándose en los derechos fundamentales reconocidos en las Constituciones y leyes de los Estados miembros, en el Convenio Europeo para la Protección de los Derechos Humanos y de las Libertades Fundamentales y en la Carta Social Europea, en particular, la libertad, la igualdad y la justicia”.

No pasaron de ahí tan sonoras afirmaciones, digo, y en nada incidirían de forma directa en los contenidos del articulado. Con todo, cuando menos, aunque sólo sea en el Preámbulo, ahí queda en el Tratado, como recordatorio y testimonio de una aspiración. Por otro lado, resulta evidente que la fórmula adoptada proviene directamente del Proyecto Spinelli, con la doble 
mención al caudal de DDFF de las Constituciones -y de las leyes, se añade- de los Estados miembros, de una parte, así como, de otra, al CEDH y a la Carta Social Europea.

\section{AVANZANDO A PASOS LENTOS: EL TRATADO DE LA}

\section{UNIÓN EUROPEA (1992)}

24. Seis años después, en el siguiente Tratado, iba a subirse un nuevo peldaño en la escala, ciertamente limitado, sin duda, juzgadas las cosas desde lo que era auspiciable y a la vista sobre todo de la cota hoy alcanzada, pero paso no despreciable, teniendo en cuenta especialmente la complicada forma de avanzar en las instituciones europeas, muy presente siempre la idea central expresada de que se puede querer mucho en materia de DDFF pero los Estados saben que es costoso atenerse a los compromisos que se van a rubricar. Cuando en 1992 se aprueba en Maastricht el Tratado de la Unión Europea, va a acceder ya al articulado el párrafo que venimos glosando, lo que representa un avance destacado, especialmente desde el punto de vista de lo simbólico, dado que la aparente plenitud del mismo queda empañada si se atiende a lo que el propio Tratado expresa en otro lugar.

En efecto, al artículo $\mathrm{F}$-que, más adelante, con la numeración en cifras pasaría a ser el artículo 6- se le incluye un apartado segundo, en estos expresivos términos:

"La Unión respetará los derechos fundamentales tal y como se garantizan en el Convenio Europeo para la Protección de los Derechos Humanos y Libertades Fundamentales firmado en Roma el 4 de noviembre de 1950, y tal y como resultan de las tradiciones constitucionales comunes a los Estados miembros como principios generales del Derecho comunitario".

El paso es notable pues al fin y al cabo se lleva al mayor rango normativo este compromiso para la Unión de respetar los derechos fundamentales, con lo que quedan implicados todos los 
órganos e instituciones de la misma ${ }^{34}$. En cuanto a cuales sean los DDFF referidos, diré que se concreta utilizando la fórmula de la remisión: ya está ahí disponible el $\mathrm{CEDH}$, del mismo modo que se quiere asegurar el estándar común de garantía alcanzado en los Estados miembros, para que no puedan tener base las reticencias antes referidas. La redacción es a la par un homenaje a la jurisprudencia del Tribunal de Justicia, al consagrarse la fórmula por él utilizada en ausencia de norma comunitaria expresa, de los principios generales del derecho. Y, por supuesto, con esta invitación a extraer principios generales del derecho, ya sea del Convenio, ya de las tradiciones constitucionales nacionales, se afianza el criterio de la validez y utilidad de que el juez comunitario salga a buscar la respuesta más allá del propio ordenamiento comunitario. Es decir, se quiere mantener viva esa situación, tan útil, de interconexión de ordenamientos: el sistema comunitario predetermina los derechos nacionales, pero las soluciones de éstos también pueden resultar de utilidad para completar el ordenamiento comunitario.

25. Tan destacada respuesta queda empañada de alguna manera a la vista de la solución que se da al planteamiento jurisdiccional. Se razonó antes acerca del significado para los derechos fundamentales del principio del "recurso judicial efectivo": no basta con proclamar las libertades, hay que adjuntarles una oportunidad de defensa ante un juez independiente para el supuesto de que se produzca una violación. Pues bien, cuando el artículo L, del propio texto de 1992, enumera sobre qué partes del Tratado se proyecta la competencia del Tribunal de Justicia, no iba a quedar incluido en esa zona de tutela judicial el artículo F que consagra los DDFF. Es decir, hay un compromiso inequívoco con los DDFF, pero se excepciona expresamente la regla del recurso judicial efectivo. En suma, algún avance sí, pero la solución dista mucho de resultar satisfactoria.

\section{UN PRIMER PROYECTO DE CONSTITUCIÓN (1994)}

\footnotetext{
34 Véase, por todos, de E. GARCÍA DE ENTERRÍA, la lección que pronunció en el solemne acto de investidura como doctor honoris causa en la Universidad de Bolonia, el 15 de mayo de 1992, I diritti fondamentali nel trattato di Maastricht, 10 ss. Recuérdese también lo que señala el propio profesor GARCÍA DE ENTERRÍA, El significado general del Convenio Europeo de Derechos Humanos, 40.
} 
26. Con fecha 10 de febrero de 1994, el Parlamento Europeo adoptaba una resolución por medio de la cual,

"toma nota con satisfacción de los trabajos de la Comisión de Asuntos Institucionales cuyo resultado es un proyecto de Constitución de la Unión Europea, que se adjunta en anexo, y pide al Parlamento que resulte electo en junio de 1994 que prosiga dichos trabajos a fin de profundizar los debates sobre la Constitución Europea...”

Es decir, circuló un proyecto de Constitución de la Unión Europea que, por cierto, en España tuvo bastante eco, muy activo por ejemplo el profesor García de Enterría en propagarla y divulgarla ${ }^{35}$. El párrafo segundo del Preámbulo de la misma reconocía:

"Subrayando que la pertenencia a la Unión Europea se basa en valores comunes a los pueblos que la integran, en particular en la libertad, la igualdad, la solidaridad, la dignidad humana, la democracia, el respeto de los derechos fundamentales y la primacía del Estado de Derecho".

Y, por supuesto, en el articulado de la misma había un completo Título VIII con una extensa y minuciosa enumeración de "Derechos humanos garantizados por la Unión”, donde, en 24 artículos, se enumeraban los clásicos derechos políticos pero no pocos derechos sociales y económicos, como los derechos laborales y de protección social, sin que faltara en la lista el derecho al respeto del medio ambiente (artículo 21).

Pero tan destacada iniciativa, que representaba una forma muy distinta de abordar la cuestión de los DDFF, carente del necesario apoyo político, más teniendo en cuenta lo ambiciosa que resultaba, no saldría adelante.

35 Que, en concreto, fue el tema que eligió para la lección impartida en el solemne acto de su investidura como doctor honoris causa de la Universidad de Cantabria el 28 de abril de 1995: Reflexiones sobre el proyecto de Constitución Europea, 23-41 


\section{EL INFORME DEL COMITÉ DE SABIOS (1996)}

27. Un nuevo paso memorable se produce en 1996 al publicarse el "Informe del Comité de Sabios", también llamado Informe Pintasilgo, "Por una Europa de los derechos cívicos y sociales". Un comité de siete cualificados expertos, equilibrado en cuanto a países de origen o sexo, presidido por la antigua Primer Ministro de Portugal, señora María Lourdes Pintasilgo -del que formó parte, con actuación muy activa, el profesor García de Enterría-, elaboró un documento muy rico en contenido, que fue ampliamente difundido, alcanzó notable eco en la opinión pública y consiguió que aspectos centrales de sus propuestas se recibieran en el Trabado de Ámsterdam, Se apostaba por "reforzar la ciudadanía y la democracia en la Unión tratando de manera indivisible los derechos cívicos y los derechos sociales". Se recomendaba también un sustancioso reforzamiento de los derechos sociales, profundizando en numerosos contenidos propios de los mismos. Se marcaba igualmente el destino de incluir en los Tratados un conjunto básico de derechos cívicos y sociales (Bill of Rights), especificando aquellos que gozan de una protección judicial inmediata y aquellos que tienen un carácter más programático y se profundizarán en una segunda etapa”. Se insistía especialmente en poner énfasis en la superación de toda discriminación y, entre otras muchas sugerencias, se proponía reforzar el papel del Tribunal de Justicia para actuar en defensa de los derechos fundamentales, levantándose, sin falta, las restricciones que había introducido el artículo L del Tratado de la Unión ${ }^{36}$. También se tomaba postura de manera expresa, y con una cierta energía, testimonio de una clara y consciente situación de recelo, en el sentido de que de ninguna manera, cualquiera que fuera la fórmula que se adoptara, debía llegarse a que el Tribunal Europeo de Derechos Humanos pudiera tener la última palabra en relación con los conflictos atinentes a la Unión Europea.

\section{PASO A PASO: EL TRATADO DE AMSTERDAM (1997)}

\footnotetext{
36 En esta parte sigo muy de cerca lo que había señalado en mi trabajo, Para una afirmación de los derechos fundamentales en la Unión Europea, págs. 57 y sigs.
} 
28. El Informe del Comité de Sabios fue objeto de amplia difusión y disfrutó de buena acogida. Su impronta y una opinión pública más madura, con reflejo también en la clase política, resultaron determinantes para que al año siguiente el Tratado de Ámsterdam de 1997 continuara dando pequeños pasos de progreso en nuestro tema. Por de pronto, el precepto que antes hemos glosado, el artículo F, que con la nueva numeración del TUE pasaría a ser el artículo 6, se abre con un destacado apartado primero, de nueva redacción, en estos términos:

"La Unión se basa en los principios de libertad, democracia, respeto de los derechos humanos y de las libertades fundamentales y el Estado de Derecho, principios que son comunes a los Estados miembros”.

De modo que principios comunes a los Estados miembros se proyectan con toda intención a la Unión, en esa metodología reiterada de intercambio de reglas jurídicas. Se trata de un precepto que, aparte de otras opciones, ostenta un recio contenido simbólico. Pero quedan otras alternativas, como la de ser un precepto primario plenamente operativo, abierto a que se extraigan consecuencias del mismo.

29. Como apartado segundo, el precepto reproduce literalmente lo que se había introducido en Maastricht y más arriba glosamos. Lo que sucede es que, aún con las mismas palabras, su significado es ya bien diferente, una vez que el Tratado de Ámsterdam declara abolido -influjo directo del buen eco que encontró el Informe del Comité de Sabios- aquel artículo L, de forma que ya nada impide acudir ante el Tribunal de Justicia.

30. El Tratado de Ámsterdam añade también el precepto inmediatamente siguiente, el artículo 7, fórmula importante en el campo de los derechos fundamentales: se va a habilitar la manera que tiene la Unión de reaccionar para el caso de que alguno de los Estados miembros abdicara de su compromiso de respeto a los DDFF. La historia enseña que hay que tener prevista cualquier evolución, más cuando se vive un desaforado proceso de ampliación de los Estados integrantes. ¿Qué alternativas tomar si alguno de ellos altera sus bases constitucionales y deja de estar en la zona de respeto a las exigencias del nuevo artículo 6.1 TUE? ¿O si, como ya ha 
sucedido en alguna ocasión, llegara al poder algún partido político contrario al respeto a los DDFF? El precepto introduce un procedimiento complejo, pero que ahí queda, como modus operandi y, al mismo tiempo, como advertencia a cualquier posible desfallecimiento.

Sin entrar ahora en mayores detalles, diré sólo dos cosas sobre este artículo 7. Ante todo que, por recordar el "guión” que antes se subrayaba, sería una respuesta a la previsión marcada en el artículo 4.4 del Proyecto Spinelli, de establecer sanciones "en el caso de violación grave y persistente por parte de un Estado de los principios democráticos o de los derechos fundamentales". Para advertir, en segundo lugar -y con ello concluyo ya la referencia a este punto-, que, con diversas modificaciones, la regla continúa hoy en el actual artículo 7 TUE.

\section{EL INFORME SIMITIS (1999)}

31. Se rompen las inercias y se van dando pasos. En este panorama se inserta el nuevo paso que debo referir, fruto del deseo de avance y profundización que se observa inequívocamente en la Comisión, lo mismo que en otros órganos europeos. Tras los resultados del Tratado de Ámsterdam, puesta la vista siempre en preparar las actuaciones futuras, se piensa en una nueva convocatoria al objeto de determinar la situación de los derechos fundamentales en la UE y las posibles salidas. Es así como la Comisión Europea, a través de la Dirección General V, sobre Empleo, Relaciones Laborales y Asuntos Sociales, nombra un "Grupo de expertos sobre derechos fundamentales" que comienza a reunirse a partir de marzo de 1998, y al que se le encarga que fije cuál es la situación de los derechos fundamentales en los Tratados, a raíz de las reformas introducidas en Ámsterdam, cuáles son los problemas jurídicos y constitucionales inherentes, así como que prepare los materiales para lograr una posible Declaración de Derechos -jese ansia por alcanzar un Bill of Rights a la altura de nuestro tiempo!-, con vistas todo ello a la siguiente revisión de los Tratados. Se optó por un grupo de 8 especialistas en DDFF, nombrados a título personal y no a propuesta de los Estados-, si bien se procuró, como es habitual en las cosas de la Unión Europea, asegurar un cierto reparto territorial y procurar un equilibrio entre los sexos. Lo presidiría el profesor griego Spiros Simitis, catedrático en la Universidad alemana de Frankfurt - 
de ahí que el documento resultante se conozca como "Informe Simitis"-, y tuve el honor de formar parte del mismo. Tras los correspondientes trabajos, y tras debatir con representantes de la plataforma de organizaciones no gubernamentales europeas del sector social, y también con representantes de los interlocutores sociales europeos, en febrero de 1999 se presentaría el Informe, con título bien expresivo: "Afirmación de los derechos fundamentales en la Unión Europea. Ha llegado el momento de actuar”.

Junto a la existencia real y efectiva de un consolidado acervo de DDFF que resulten eficaces, preocupa de manera esencial su presencia y fácil localización, lo que podemos denominar la ostensibilidad ${ }^{37}$. Se glosaba antes el artículo 6.2 TUE, con su remisión a los derechos fundamentales tal y como se garantizan en el Convenio de Roma. Llegar a eso ha representado un avance importante cuyos esfuerzos hay que valorar. Pero el documento estima que eso no es suficiente, que la meta hoy debe abarcar un horizonte más nítido. Se recomienda por eso el "reconocimiento explícito", nominatim, de cada uno de los derechos. Pormenorización por tanto de la lista de derechos del CEDH, así como de aquellos de los Protocolos Adicionales en que hay un grado de consenso. Pero compromiso también de pensar en incorporar otros nuevos. Si los contenidos del CEDH ofrecían un sustrato ya asumido y consolidado, gozando de amplia aceptación y, por ende, de inexcusable reflejo inmediato, se aludía también a nuevos valores, hoy muy sensibles en la opinión pública, a los que habría que ir prestando atención tratando de incorporarlos cuando se pudiera. Se menciona así, en primer lugar, la cláusula antidiscriminatoria, con la redacción modernizada que, en parte, se ofrece ya en algún pasaje de los Tratados. Se van a incluir también, entre los ejemplos, la libertad de elección de empleo, el derecho a limitar el uso de los datos personales, el derecho a la reagrupación familiar, el derecho a la negociación colectiva,

$37 \quad$ Hay un dato elemental que debe ser resaltado: el sistema comunitario a fuerza de numerosos estirones había ido creciendo en funciones y cometidos, también en cuanto a extensión geográfica. Sin demasiado orden ni concierto el contenido de los Tratados se había ido incrementando asumiendo muy variadas regulaciones. Pues bien, lo cierto es que a consecuencia de dicho proceso no era difícil constatar cómo en el Derecho comunitario ya vigente, es decir, en los Tratados, si bien de manera dispersa y con muy diferente densidad jurídica, había un acervo muy consistente de previsiones directamente relacionadas con lo que llamamos los derechos fundamentales. Resultaba decisivo ordenar, sistematizar y hacer ostensible todo ese material. Por eso, en el curso de los trabajos preparatorios en el seno del Comité Simitis me pareció interesante elaborar un documento -simple trabajo de "cortar y pegar"-reuniendo algunas de las manifestaciones referentes a los derechos fundamentales, dispersas a lo largo de los Tratados. Lo he publicado recientemente bajo el título, Los derechos humanos y las libertades fundamentales según los Tratados en que se basa la Unión Europea, 405 ss. 
y a recurrir a la acción colectiva en caso de conflicto de intereses, y el derecho a la información, la consulta y la participación, por lo que se refiere a decisiones que afectan a los intereses de los trabajadores.

Parte el documento de la convicción de que el proceso de codificación de los DDFF es un proceso abierto que ha de tener en cuenta las posibilidades, aspiraciones y necesidades de una sociedad marcada por cambios constantes. En este sentido se insta a madurar reflexiones en la idea de que, sin falta, habrá que dar acogida también a los derechos referidos a la protección del medio ambiente y a los efectos de la biotecnología.

Estaba también el importante aspecto de técnica jurídica de pensar en el sistema de fuentes del derecho y de su jerarquía. Pues bien, el documento apuesta, y es la última de las Recomendaciones, porque se dé a las respuesta en materia de DDFF el más alto rango normativo. Por ello se propone que figure en los Tratados. Sin concretar en cuál de ellos ni dónde, pero de manera reunida, conjunta y unitaria, deseablemente, "en una parte especial o en un título particular". Se considera la importancia del "dónde", tanto desde la línea de lo simbólico como desde la eficacia. Por eso el Informe se cierra con estas palabras: "El lugar elegido debería ilustrar claramente la importancia de los derechos fundamentales e indicar sin lugar a dudas que las actividades de la Unión Europea deben guiarse siempre, y en cualquier circunstancia, por el respeto a estos derechos".

Concluiré señalando que el documento del Comité Simitis halló muy favorable acogida en los dos Consejos Europeos que se celebraron tras su elaboración, el de Colonia (3-4 de junio de 1999) y el Tempere (15-16 de octubre de 1999), correspondientes a las respectivas Presidencias alemana y finlandesa. Hasta el punto de que se acordaría crear una nueva comisión de amplio espectro representativo, en la que tanto las instituciones comunitarias como los Estados miembros jugaran un papel destacado. Es así como se llega a la constitución del llamado "Grupo de los 62" que protagonizaría el empeño de elaborar la Carta Europea de los Derechos Fundamentales. 


\section{LA ELABORACIÓN DE LA CARTA (2000)}

32. Las reflexiones que más arriba se formulaban acerca de si hay unos tiempos propicios para la codificación de las declaraciones de derechos, pueden traerse a colación ahora al tratar de la elaboración de la Carta. Acaso no se daba esa situación de cambio radical, ese impulso imparable que aparece en algunos momentos históricos, pero cada vez se era más consciente de la necesidad de asegurar una consistente presencia de derechos fundamentales en el ámbito de la UE. Y aunque no situaciones objetivas radicales, había sí circunstancias que ayudaban. La Unión había crecido de manera espectacular y sin duda era mucho más que una "Comunidad Económica” o un "Mercado Común”. La Unión había llegado a acumular muy importantes poderes y a desempeñar numerosísimas funciones. Nunca se configuró como un Estado o como una Federación de Estados, pero su protagonismo en el ámbito de lo público había llegado a ser de gran magnitud. De ahí la necesidad de límites y contenciones para lo que, junto a otras fórmulas jurídicas, los derechos fundamentales están llamados a desempeñar un destacado papel, tal es su innegable funcionalidad. Los políticos eran bien concientes de ello y la opinión pública más cualificada estaba en gran medida imbuida del tema. Coincidieron también algunos elementos simbólicos. Por de pronto, el efecto taumatúrgico de las cifras: el 4 de noviembre de 2000 iban a cumplirse 50 años del Convenio de Roma, que sería la base del sistema de Estrasburgo. ¡Buen momento para hacer una nueva declaración de derechos, moderna y puesta al día, espejo fiel de las nuevas aspiraciones que habían ido surgiendo a lo largo del periodo!. Incluso -ihoy bien sabemos que pasó sin pena ni gloria!- se esperaban los fastos del final y principio de siglo y de milenio. El caso es que coincidieron las constelaciones y los políticos decidieron iniciar la aventura de dar el paso de elaborar una nueva declaración de derechos.

33. Ante las frecuentes críticas de burocratismo y de falta de trasparencia, tantas veces dirigidas a la Europa comunitaria, se optó decididamente por una fórmula abierta y participativa, que se distanciara de las habituales reuniones de burócratas que en las conferencias intergubernamentales, una vez agotado el fulgor del impulso inicial de los políticos, han solido ser los encargados de redactar los documentos de la Unión. Para marcar claramente una diferencia, al 
grupo de trabajo se le iba a denominar la "Convención", término tan grato a los franceses, que desempeñarían muy destacado papel en la elaboración (no se olvide que la fase más intensa de los trabajos así como la culminación, coincidiría con el “Semestre Francés”, el segundo de 2000).

Se quiso involucrar a unos y otros en la elaboración del texto, en esa UE integrada entonces por 15 Estados. Es así como, ante todo, se planteó el llamado “Grupo de los 62”, que responde a la idea de aglutinar representantes de las instituciones europeas -la Comisión y el Parlamento-, de los Parlamentos nacionales y de los Jefes de Gobierno de los 15 Estados. Estos últimos se esmeraron en cuidar la selección designando a personas bien cualificadas, por sus conocimientos jurídicos pero también por su temple cívico, uno por cada Estado. Alemania nombró a Roman Herzog que había sido Presidente del Tribunal Constitucional, Presidente también de la República Federal Alemana, que resultaría elegido presidente de la Convención. Francia envió al cualificado jurista del Conseil d'Etat y destacado europeísta, Guy Braibant recientemente fallecido-, que sería elegido Vice-Presidente, aunque en gran parte desempeñaría la presidencia debido a los impedimentos familiares de Herzog. Braibant, desde su experiencia, conocimientos y buen tino, jugaría un papel muy activo y eficaz en la elaboración de la Carta, eficazmente apoyado por la conocida internacionalista de París y ella misma cualificada europeísta, Jacqueline Dutheil de la Rochère. Italia envió a Stefano Rodotà. El Presidente del Gobierno Español optaría por quién había sido Presidente del Tribunal Constitucional, profesor Álvaro Rodríguez-Bereijo, muy activo también, buen testimonio de que España se interesó muy a fondo por la Carta: alecciona considerar que por una vez se nombra a una persona por su valía y experiencia y no fueran razones partidistas las determinantes. Luego, curiosamente, uno de los primeros trabajos escritos sobre la Carta sería su lección pronunciada en octubre de 2000 en el solemne acto de apertura de curso académico en la Universidad Autónoma de Madrid.

Cada uno de los 15 Estados mandó asimismo a dos representantes de su Parlamento. Las Cortes Generales se esmeraron también a la hora de seleccionar a sendas personas bien cualificadas, Gabriel Cisneros y Jordi Solé Tura: presencia de ambas Cámaras -diputado el primero y senador, luego, el segundo-, distintas sensibilidades políticas y geográficas, pero también el dato relevante de que ambos habían sido miembros del grupo de los 7 que redactó la 
famosa "Ponencia Constitucional" (excelentes personas ambos y muy competentes, por desgracia recientemente fallecidos).

Desde las instituciones europeas, la Comisión envió un representante -persona de tanto fuste como Antonio Vitorino, Comisario a la sazón-, y el Parlamento Europeo 16, delegación que por cierto estuvo presidida por el español Ińigo Méndez de Vigo, europeísta de gran prestigio y que trabajó muy activamente en el desarrollo de la Carta. A los 62 se unieron varios observadores, entre ellos, 2 representantes del Tribunal de Justicia y 2 del Consejo de Europa, uno de ellos, Marc Fischbach, el juez luxemburgués en el TEDH.

Me parece muy de destacar este amplio abanico, esta composición tan abierta y representativa, fórmula ideal en una doble dirección, ante todo para hacer llegar opiniones variadas y diversas, tanto en la escala política como en relación a los aspectos geográficos y culturales, pero también a la hora de dar prestigio y avalar el trabajo resultante.

34. Junto a la composición, es de justicia resaltar la metodología de trabajo que se impuso: la más absoluta trasparencia en debates e intervenciones, toda la documentación practicable en Internet, que funcionó también en doble dirección, para facilitar información con la mayor amplitud posible, de manera que todo pudiera llegar al público, pero también para recibir propuestas y sugerencias de quien quiso hacerlas llegar, que fueron muchos.

Y la Convención trabajó... y consiguió sus objetivos. Personalmente, seguí muy de cerca los debates, a través de varios participantes, y sé bien que tuvieron que emplearse a fondo. Era empeño difícil pues había que aprobar un texto por unanimidad. Complejo y delicado concertar tantos intereses contradictorios, atender a tan diversos y, a veces, poderosos grupos de presión, y sortear tendencias optando por la fórmula más correcta. Valgan como ejemplo dos detalles, que podrían parecer anecdóticos, pero que en el fondo eran de gran significado.

35. En un momento determinado, un influyente grupo de feministas, no sé si desde la ignorancia o la osadía, logró que lo que era la gran expresión de la superación del Ancien Régime, 
intentando superar discriminaciones sociales, familiares, religiosas y políticas ancestrales, que abría la Declaración de Derechos del Buen Pueblo de Virginia (12 de junio de 1776), "Que todos los hombres son por naturaleza igualmente libres", o que la Declaración de Derechos del Hombre y del Ciudadano de la Revolución Francesa (26 de agosto de 1789) cincelaba, también en su artículo primero, afirmando que "Los hombres nacen y permanecen libres e iguales en sus derechos", o que la DUDH (10 de diciembre de 1948) con fórmula más moderna expresaba recalcando que "Todos son iguales ante la ley y tienen, sin distinción, derecho a igual protección de la ley", logró, digo, que quedara reducido - en un irresponsable ejercicio de reduccionismo- a una confrontación entre mujeres y varones. En efecto, tal y como figura en el Proyecto el 28 de julio de 2000, el artículo 20, destinado a abrir el capítulo sobre "Igualdad", ofrecía la siguiente redacción: "Todas las personas, hombres y mujeres, son iguales ante la ley". Recuerdo como funcionaron los teléfonos y al final se pudo enderezar el entuerto, alcanzándose la redacción que hoy rige: "Todas las personas son iguales ante la ley". Por supuesto que la no discriminación por razón del sexo tiene cabida, amplia cabida, pero allí donde corresponde, así, artículos 22 y 21, pero no en aquel otro lugar inicial y, sobre todo, sin desplazar el gran planteamiento frente a todas las desigualdades históricas y ancestrales. Entiendo que la cuestión no es en absoluto baladí.

36. Otro detalle, tampoco intrascendente: grupos religiosos -alguno muy cualificadoiniciaron una labor de descalificación de la Carta porque en el Preámbulo no se aludía a connotaciones religiosas concretas que -sostenían- habrían sido determinantes en la historia de Europa. Entiendo que la Carta es sumamente respetuosa con el hecho religioso, al que dedica señalados preceptos, como los artículos 10, 14, ó, 22. Lo que provocaba sus censuras era que al comienzo del Preámbulo se arrancara afirmando sólo: “[La Unión] consciente de su patrimonio espiritual y moral...”. El representante francés protestó en el sentido de que el sistema constitucional de su país, que consagra como principio decisivo el de laicidad, no le permitía precisar más. Y así quedó, acertadamente, según mi opinión, aparte de que, de querer añadir referencias más concretas, se abría luego la discusión de cuántas, y en qué términos, se tomarían en consideración. 
37. En suma, que organizaciones, sectores y grupos de presión, tenían cada uno sus aspiraciones, y los responsables tenían que ponderar y seleccionar. Pero otra faceta muy importante en la discusión de la Carta, y que se refleja sobradamente en el texto aprobado, tiene que ver con el aspecto que se recalcó de la preocupación de algunos Estados por los compromisos que pudieran derivárseles. De forma señalada desde el momento en que quedó claro que la declaración de derechos que se fraguara tenía que acoger por fuerza un paquete señalado de derechos sociales. Curiosamente, países avanzados y que tempranamente habían abordado y resuelto en su ámbito interno bien destacadas prestaciones sociales, países a la par cumplidores y respetuosos con la ley, eran muy reticentes a la codificación en términos amplios e inconcretos de derechos sociales: dichas reticencias han acompañado a la Carta en todo momento, en el proceso de elaboración, a la hora de decidir qué efectos tendría tras la aprobación, pero también luego, pues como se dirá, aún después, tendría que sufrir algún retoque, exponerse a una contextualización o, incluso, tener que sufrir directamente el práctico desenganche de algún Estado. Pues bien, en esta fase de la elaboración, había Estados que querían a toda costa saber a qué atenerse, saber a qué se comprometían, desde una desconfianza neta además, como se indicó, al activismo judicial, objeción siempre muy presente. De destacar en este sentido de freno, por ejemplo, la labor de zapa de los representantes de Suecia y del Reino Unido.

38. Fue difícil, pero a pesar de las reticencias, la Carta se hizo y fue aprobaba por unanimidad. Para lograr lo cual -y ni aún así quedó vacunada frente a ulteriores reticencias- hubo que hacer todo tipo de concesiones. Como que, por ejemplo, como más adelante se precisará, que junto a los preceptos de aplicación directa, inmediata e inequívoca, haya otros necesitados por fuerza de la intermediación del legislador -el legislador interno, en concreto-, que será quien marque en su caso el quantum de las obligaciones para cada Estado. En cierta manera, al modo de la metodología de lo que en la CE son los principios rectores de la política social y económica, que precisan por fuerza de la intermediación del legislador, cuyas concreciones delimitan rigurosamente la labor aplicativa de los jueces. De ahí que en el sistema de la Carta se adopte la terminología que bien expresa la afirmación última del Preámbulo: "En consecuencia, la Unión reconoce los derechos, libertades y principios enunciados a continuación”. Habrá derechos, pero 
también principios, sustento de un compromiso mucho más difuso y alejado. Es decir, se trata de un texto cuyos contenidos tendrán muy diversa densidad jurídica.

\section{LA APROBACIÓN DE LA CARTA (2000)}

39. Los miembros de la Convención cumplieron y el texto de la Carta fue objeto de todas las aprobaciones necesarias. Aunque enseguida iba a plantearse un nuevo interrogante: ¿Qué iba a suceder con la Carta una vez aprobada? ¿Cuáles serían sus efectos jurídicos?

Pero vayamos por partes. En la gloria del semestre francés, la Convención, en Bruselas, aprobó el texto como proyecto el 2 de octubre de 2000. El Consejo Europeo de Biarritz (13 y 14 de octubre de 2000) dio su acuerdo unánime al proyecto y lo envió al Parlamento Europeo y a la Comisión. Ambos lo aprobaron, el Parlamento el 14 de noviembre, y la Comisión el 6 de diciembre de 2000. Y, en sesión solemne, la Carta fue firmada y proclamada en Niza -de ahí que a veces se la denomine la "Carta de Niza"-, el 7 de diciembre de 2000, por la Presidenta del Parlamento Europeo, Nicole Fontaine, por el Presidente del Consejo Europeo, el a la sazón Presidente de la República Francesa, Jacques Chrirac, y por el Presidente de la Comisión, Romano Prodi. El día 18 de diciembre de 2000 aparecería en el "Diario Oficial de las Comunidades Europeas".

Ya tenemos la Carta aprobada, proclamada y publicada en el "diario oficial”. Aún así, se va iniciar un nuevo periodo cuajado de sorpresas e incertidumbres que sólo se ha cerrado el pasado 1 de diciembre de 2009 con la efectiva entrada en vigor de la Carta. Porque para llegar al quid de la cuestión habrá que responder al interrogante de qué es en realidad como instrumento jurídico esa Carta que fue aprobada en diciembre de 2000. Y es que toda organización pública tiene unas reglas jurídicas de funcionamiento, necesarias e imprescindibles. La imposición de mandatos en los sistemas públicos pasa por la elaboración de unos instrumentos normativos y su encaje en el sistema de fuentes del Derecho. Pues bien, hubo consenso para aprobar la Carta, pero no para convertirla en un instrumento normativo de efectos vinculantes con carácter general. La 
Carta, ni se llevó a los Tratados ni se la dotó de fuerza jurídica a través de cualquier otra modalidad. Quedó en un mero documento, rico en presencia y contenido, pero carente de fuerza. Por recordar la terminología que antes se expuso, se atendió a la faceta de lo simbólico pero no a la de la operatividad jurídica.

En esos momentos iniciales de perplejidad, unos y otros nos pronunciamos tratando de abordar la situación ${ }^{38}$. Extractaría mi posición personal de entonces en los siguientes tres puntos.

A). Dado que la Carta es en gran medida una codificación ordenada de reglas jurídicas ya existentes con anterioridad, aunque no se haya presentado en la veste de un instrumento normativo, es obvio que todos esos mandatos anteriores siguen en vigor y son de aplicación.

B). Por otra parte, el respaldo solemne que le dieron los tres representantes de las más importantes instituciones comunitarias, significaba que éstas se estaban autovinculando con el documento. Así ha sucedido de hecho, en línea con la claridad de las palabras que se pronunciaron en el solemne acto de la firma y proclamación. La Presidenta Fontaine afirmó: "En adelante, la Carta será nuestra referencia para todos los actos del Parlamento Europeo que afecten directamente a los ciudadanos de la Unión". Por su parte, el Presidente Prodi afirmaría: "Para la Comisión, la proclamación marca el momento en que las instituciones se comprometen a respetar la Carta en todas las acciones y políticas de la Unión"39. En este sentido, me parece especialmente significativo lo que afirmaba la Comisión en su Comunicación de 27 de abril de 2005 (COM, 2005, 172 final), sobre "Respeto de la Carta de Derechos Fundamentales en las propuestas legislativas de la Comisión. Metodología para un control sistemático y riguroso”:

"La Comisión decidió, el 13 de marzo de 2001, que toda propuesta de acto legislativo y todo acto reglamentario que deba adoptar el Colegio de Comisarios serían objeto, en el momento de su elaboración y de conformidad con

\footnotetext{
$38 \quad$ Me remito a mi trabajo, La eficacia de la Carta, que fue originariamente una conferencia pronunciada en San Sebastián y en otros foros diversos.

39 He tomado las palabras del folleto de la "Oficina de Publicaciones Oficiales de las Comunidades Europeas", que publica la Carta.
} 
los procedimientos habituales, de un control previo de compatibilidad con la Carta de los Derechos Fundamentales de la Unión Europea. Decidió también que las propuestas legislativas y los actos reglamentarios que presenten un vínculo específico con los derechos fundamentales serán objeto de una declaración formal de compatibilidad mediante un Considerando que confirme el respeto de la Carta. El legislador mantendrá en adelante sistemáticamente este Considerando”.

Es decir, no habría fuerza jurídica para llevar los preceptos de la Carta como argumento ante los Tribunales, no se cumplía el criterio de la existencia de un recurso judicial efectivo, pero no obstante era de destacar que las propias instituciones europeas se consideraban vinculadas por la Carta.

C). Pero a su vez, y en tercer lugar, había otro aspecto no despreciable: la Carta quedaba instalada como documento de prestigio, abierta a quien la quisiera utilizar. Siempre ha sucedido así con las grandes declaraciones de derechos. De recordar, por ejemplo, como se propagó la Declaración de Derechos del Hombre y del Ciudadano de 1789 por las colonias españolas de América del Sur, con la temprana traducción hecha por Nariño en Bogotá, o por Picornell en Caracas. Pues también con la Carta se abrió una situación de expectativa, muy pendientes todos de ver si alguno de los Tribunales cualificados utilizaba la Carta en sus argumentaciones. Fue una sorpresa que el propio Tribunal Constitucional español la citara en su apoyo, antes incluso de estar formalmente aprobada, en la sentencia 292/2000, de 30 de noviembre. Y quienes estábamos en el ajo, nos comunicábamos cualquier referencia, ya en los Informes del Abogado General en el Tribunal de Luxemburgo, ya incluso en la jurisprudencia de Estrasburgo, inicialmente en los votos particulares -muy temprana referencia así en el voto particular del juez francés J. P. Costa en la sentencia "Hatton I c. Reino Unido", de 2 de octubre de 2001-, y luego llegando al texto de la mayoría ${ }^{40}$. Quedaba abierto, en suma, un proceso de recepción y afianzamiento, aunque, sin duda, de mayor fuerza simbólica que efectiva.

\footnotetext{
40 Véase también, a modo de muestra, siempre del TEDH, las sentencias "Frette c.Francia”, de 26 de febrero de 2002, "Bosphorus c. Irlanda", de 30 de junio de 2005, o la decisión sobre admisibilidad "Vahan Bayatyan c. Armenia", de 12 de diciembre de 2006.
} 


\section{EL PROYECTO DE TRATADO ESTABLECIENDO UNA} CONSTITUCIÓN PARA EUROPA (2004)

40. Así las cosas, se alumbró un rayo de esperanza cuando en 2004 apareció el Proyecto de Tratado estableciendo una Constitución para Europa: en la nueva propuesta se daba el paso mayúsculo de insertar la Carta dentro del propio Tratado, como Parte Segunda, lo que suponía que, de salir adelante la idea, adquiriría estatus pleno dentro del sistema constitucional de la Unión Europea. Una vez convertida en norma constitucional del máximo rango, ya no habría duda alguna acerca de su eficacia y efectos. Todo el texto de la Carta, Preámbulo incluido, quedaba incorporado, aunque los artículos perdían la numeración originaria para insertarse con normalidad en el conjunto del Tratado. De hecho, los preceptos de la Carta se incluían en la nueva numeración del II-61 al II-114.

41. Pero, de nuevo, aparecieron las reticencias a que antes me refería: al ver que, al fin y al cabo, la Carta iba en serio, hubo de sufrir unas cuantas innovaciones, pequeñas en apariencia pero de cierto alcance, desde la idea de proteger los derechos nacionales, con la determinación de asegurar que la Carta no atribuyera nuevas competencias a la Unión, muy presente también la idea de que la declaración de derechos no disparara el activismo judicial.

Es curioso observar que dichas reformas, aparte de adecuar la inserción en el nuevo Tratado, no afectan por así decir a los aspectos sustantivos de la Carta, es decir, a los contenidos de la declaración de derechos, sino a la vertiente aplicativa, lo que algunos llaman las disposiciones transversales, incluidas en el Título VII, con la rúbrica originaria de "Disposiciones generales", que se cambia en el Proyecto de Constitución, para pasar a decir, con fórmula hoy mantenida, "Disposiciones generales que rigen la interpretación y la aplicación de la Carta". Pero tales disposiciones son la llave de paso a la hora de dar aplicación a los contenidos sustantivos, de ahí que sí importen especialmente. 
Cuando se hizo la Carta, la Convención elaboró unas "Explicaciones" con la intención de aclarar cual era el origen y de donde provenía cada uno de los párrafos o artículos: si había sido tomado del TUE, o del CEDH, si se tomó de las tradiciones constitucionales, o de la jurisprudencia de Luxemburgo, o de Estrasburgo, etc. Junto al efecto explicativo, dicho documento responde también a la idea de asegurar que la Carta no es innovadora, sino que lo único que hace es codificar mandatos ya existentes pero que estaban dispersos; algo se dirá sobre esto más adelante. Cumpliría así una función que tantas veces se repite en la evolución europea, el pequeño tributo pagado a los euroescépticos en el sentido de aseverar que no se estaban ampliando las competencias de la Unión. Pues bien, el documento con las "Explicaciones", destinado a quedar en el expediente sobre la elaboración de la Carta, fue rescatado o resucitado por el Proyecto de Constitución para darle valor formal, desde la idea señalada de contribuir a marcar límites.

En concreto, a su paso por el trámite de elaboración del Proyecto de Tratado constitucional, se incorporarían a la Carta estos tres tipos de añadidos, breves sin duda, y reiterativos, que para nada la embellecen o simplifican, sino al contrario, pero que responden a la indicada tónica de recelo, desde la preocupación por la defensa de los ámbitos nacionales, y que, como se verá, van a responder a dos ideas centrales, tan vinculadas entre sí, tan polémicas siempre como en gran medida irreales, la de que los preceptos de la Carta no amplían las competencias de la Unión en detrimento de los Estados y la de que, en éstos, no dan nuevas opciones a los jueces más allá de las que han venido ostentando según el Derecho nacional vigente.

A). Ante todo, al importante párrafo quinto del Preámbulo, que es el que explica de dónde provienen los materiales que han servido para componer la Carta, se le incorpora el siguiente añadido:

"En este contexto, los órganos jurisdiccionales de la Unión y de los Estados miembros interpretarán la Carta atendiendo debidamente a las explicaciones elaboradas bajo la autoridad del Presidium de la Convención que redactó la Carta y actualizadas bajo la responsabilidad del Presidium de la Convención Europea”. 
Con la particularidad de que, como se va a poder comprobar enseguida, lo que se ha llevado al Preámbulo, se incluirá también, en términos similares, en el articulado (así, artículo II.112.7 del Proyecto de Constitución, y artículo 52.7 del texto hoy vigente).

B). De nuevo dos ańadidos, no muy sistemáticos, y siempre reiterativos, rechazando de forma expresa que la Carta aumente las competencias de la Unión: en el artículo sobre "Ámbito de aplicación” -el II.111 en el Proyecto de Constitución, y el 51 actual- se agregan sendas frases, en el apartado 1, "y dentro de los límites de las competencias que se atribuyen a la Unión en las demás partes de la Constitución”; y en el apartado 2, "no amplia el ámbito de aplicación del Derecho de la Unión más allá de las competencias de la Unión”.

C). Se quiere poner énfasis en que la Carta junto a derechos incluye también "principios", de manera que en relación con estos últimos habrán de resultar determinantes las precisiones que haga en cada caso el legislador, ya sea el comunitario ya el de cada uno de los Estados. Pues bien, en esta línea, con el afán de fortalecer la interpretación que tradicionalmente habían venido dando los jueces de cada Estado al aplicar el Derecho nacional existente, se van a añadir cuatro apartados al final del originario artículo 52 (II.112 en la numeración del Proyecto de Constitución), del mismo modo que se sustituye la rúbrica originaria, "Alcance de los derechos garantizados", que pasará a decir "Alcance e interpretación de los derechos y principios". Estos son los apartados añadidos:

“4. En la medida en que la presente Carta reconozca derechos fundamentales resultantes de las tradiciones constitucionales comunes a los Estados miembros, dichos derechos se interpretarán en armonía con las citadas tradiciones.

5. Las disposiciones de la presente Carta que contengan principios podrán aplicarse mediante actos legislativos y ejecutivos adoptados por las instituciones, órganos y organismos de la Unión, y por actos de los Estados miembros cuando apliquen el Derecho de la Unión, en el ejercicio de sus competencias respectivas. 
Sólo podrán alegarse ante un órgano jurisdiccional en lo que se refiere a la interpretación y control de la legalidad de dichos actos.

6. Se tendrán plenamente en cuenta las legislaciones y prácticas nacionales según lo especificado en la presente Carta.

7. Las explicaciones elaboradas para guiar en la interpretación de la Carta de los Derechos Fundamentales serán tenidas debidamente en cuenta por los órganos jurisdiccionales de la Unión y de los Estados miembros.

42. Puede sorprender esta línea zigzagueante y reiterativa, que acaso no se entienda bien, y de cuya eficacia cabe dudar pues a la postre el Tribunal de Justicia, supremo intérprete del ordenamiento comunitario, y tan activo siempre, hará lo que tenga que hacer, pero estos son los pequeños peajes que han estado presentes siempre en la construcción europea, y que no queda más remedio que admitir si se quiere seguir avanzando. Al margen de ello, creo estará en el ambiente la buena disposición con que se recibió en España el Proyecto de Constitución Europea. Personalmente recuerdo la ilusión con que la contábamos a los alumnos, y aún dí varias conferencias sobre ella. En España, el Proyecto fue incluso sometido a referendum y aprobado (aunque al final el Gobierno se viera apurado, pues no había calculado bien las reacciones, y las cosas no son tan sencillas como parecen). Pero, de nuevo, el sino de la Carta se torció y la realidad nos sorprendió con una cierta brusquedad: se recordará como se agostó la iniciativa, primero con el fracaso del referendum francés, en el que coincidieron motivaciones tan diversas, y después con el del holandés. Una meta que parecía estar al alcance de la mano quedó de pronto frustrada de manera un tanto inimaginable.

XIX. HACIA EL TRATADO DE LISBOA (2007): NUEVOS “PEAJES” A TRAVÉS DE PROTOCOLOS Y DECLARACIONES

43. Afortunadamente los líderes europeos con más peso político reaccionarían con agilidad de reflejos - de manera muy señalada la Canciller alemana, Señora Merkel- y, con decisión, se puso en marcha la operación que culminaría con la aprobación del Tratado de Lisboa. 
Empalmamos así con lo que se señalaba al comienzo : ya está en vigor el Tratado de Lisboa y, por ende, la Carta. Pero a ésta aún le aguardaban ciertos episodios en la última etapa de su larga travesía que convendrá precisar.

Como puntualiza el artículo 6.1 TUE que al comienzo se transcribió, la Carta entró en vigor "tal como fue adoptada el 12 de diciembre de 2007", texto que se publicaría en el "Diario Oficial de la Unión Europea” el 14 de diciembre de 2007. En efecto, el texto de la Carta que se manejaba, aún sería modificado. Al cerrarse el TL fue objeto de algunas adaptaciones. Las innovaciones introducidas para la Constitución ya no se tocarían a pesar del fracaso de ésta, de modo que se mantienen, pero en cambio algunas expresiones se ajustaron el nuevo contexto, pues hubo que poner al día, por ejemplo, las anteriores referencias a la Constitución. Así es como ha pasado a entrar en vigor la Carta, debiendo advertir que para aplicarla con corrección habrá que tener a la vista también las "Explicaciones" ${ }^{1}$, de acuerdo con lo que antes se indicó. Lo cual no deja de ser un pequeño engorro, aparte de que hace más pesada esta nueva declaración de derechos que, como todas, aspira a la simplicidad. Pero bueno, lo que cuenta es que la Carta está hoy por fin vigente. Conviene con todo hacer una advertencia. Las dos ideas que se introdujeron en la Carta con motivo de la tramitación del Proyecto de Tratado estableciendo la Constitución continúan presentes en la Carta, como digo, pero a su vez, con toda intención, y desde esa tónica reiterativa que yo no acabo de compartir, el TL las ha llevado también al articulado del propio TUE. Ya transcribí el párrafo primero del apartado 1 del artículo 6. Pues bien, conviene tener muy presente que en dicho apartado primero, a continuación, se han incluido los dos siguientes párrafos:

"Las disposiciones de la Carta no ampliarán en modo alguno las competencias de la Unión tal como se definen en los Tratados.

Los derecho, libertades y principios enunciados en la Carta se interpretarán con arreglo a las disposiciones generales del Titulo VII de la Carta por las que se rige su interpretación y aplicación y teniendo debidamente en cuenta las

\footnotetext{
${ }^{41}$ Incorporadas, con anotaciones precisas, al cómodo e interesante volumen de Ricardo ALONSO GARCÍA y Pablo GONZÁLEZ SAQUERO, Código de Derechos Fundamentales, que es por donde yo las cito.
} 
explicaciones a que se hace referencia en la Carta, que indican las fuentes de dichas disposiciones".

Se mantiene en la Carta, decía, el texto que se adoptó para el Proyecto de Constitución, aunque hay que precisar algo más, dado que si el texto no se ha tocado más allá de lo que acabo de señalar, el alcance de su vigencia si ha resultado afectado a través de algunas circunstancias sobrevenidas que sí han venido a añadir algo al proceso: nuevo "peaje” que ha habido que pagar como es usual- para que el proyecto saliera adelante.

44. En efecto, en la procesión de instrumentos complementarios que, a los efectos de puntualizar, suelen acompañar a cada uno de los Tratados, como testimonio de los acuerdos, reservas o excepciones que ha habido que admitir con efectos individuales para que el documento principal pudiera salir adelante, debo referirme ahora, desde la panorámica no sólo de todo lo que comprende, sino también de todo lo que complementa al Tratado de Lisboa, a dos de los "protocolos", con incidencia directa en la efectividad del tratado, recuérdese, y a cuatro "declaraciones", una de ellas conjunta, y las otras tres de Estados singulares.

A). De entre las Declaraciones conjuntas de la Conferencia, la número 1 se refiere directamente a la Carta. Es muy breve y consta de dos cortos párrafos. El primero, al recordar que la Carta "tiene carácter jurídicamente vinculante", insiste en que "confirma los derechos fundamentales garantizados por el Convenio Europeo de Derechos Humanos y tal y como resultan de las tradiciones constitucionales comunes a los Estados miembros".

El segundo párrafo es una nueva manera de insistir sobre idea bien reiterada cuanto aburrida, cuando afirma:

"La Carta no amplia el ámbito de aplicación del Derecho de la Unión más allá de las competencias de la Unión ni crea ninguna nueva competencia ni ningún nuevo cometido para la Unión y no modifica las competencias y cometidos definidos por los Tratados". 
B). Más importancia tiene el Protocolo número 30, referido también a la Carta, y que va a marcar claras excepciones de aplicación a favor del Reino Unido y de Polonia: se afirma directamente que la aprobación de la Carta en absoluto permite que ni los jueces de ambos Estados ni el TJUE puedan contrastar normas o decisiones dictadas dentro de ambos Estados con las disposiciones de la Carta (artículo 1.1). Vale la pena transcribir íntegro el apartado 2 de dicho artículo primero:

"En particular, y a fin de no dejar lugar a dudas, nada de lo dispuesto en el título IV de la Carta crea derechos que se puedan defender ante los órganos jurisdiccionales de Polonia o del Reino Unido, salvo en la medida en que Polonia o el Reino Unido hayan contemplado dichos derechos en su legislación nacional”.

Se trata, como se ve de disposición ciertamente enérgica. Se insiste incluso (artículo 2) en que cuando la Carta se refiera a "legislaciones o prácticas nacionales", dicha expresión no tiene un valor genérico o de promedio, sino que debe referirse exclusivamente a la práctica de cada uno de los dos Estados: "Sólo se aplicará en Polonia o en el Reino Unido -se dice- en la medida en que los derechos y principios que contiene se reconozcan en la legislación o prácticas de Polonia o del Reino Unido”. A la hora de atar cabos, se quiere recalcar que las legislaciones o prácticas extranjeras, acaso de mayor contenido, no han de servir de motivo para dar alas en el sistema interno británico o polaco.

Advertiré que, como se ha de estudiar más adelante, el título IV de la Carta es el que bajo la rúbrica "Solidaridad" consagra los más cualificados derechos sociales: protección de la salud, seguridad social, etc., también, protección del medio ambiente. Como se explicó al comienzo, se trata de terreno muy sensible en el que las implicaciones económicas de los Estados pueden resultar cuantiosas. Pues bien, al final va a aparecer el gran quiebro del Reino Unido, de modo que, tras marear la perdiz con tanta insistencia a lo largo de todo el proceso de elaboración, condicionando en gran parte la redacción del documento, en el último momento, cuando ya sería 
inevitable que entre en vigor, se descuelga desenganchándose expresamente de cualquier alternativa no prevista en su sistema y que hubiera podido incentivar el activismo judicial ${ }^{42}$.

Debo decir que, en el fondo, en el caso del Reino Unido entiendo perfectamente la postura sostenida. El Reino Unido es un país responsable y serio, pagado de respetar sus compromisos. Hay que ver, por ejemplo, lo sucedido con los derechos y libertades del CEDH: una vez que se incorporaron al Derecho inglés a través de la "Human Rights Act" de 1998 -cuyo significado fue tempranamente resaltado entre nosotros por los profesores Ricardo Alonso García e Ignacio Torres Muro y cuya trayectoria ha seguido con atención el profesor Omar Bouazza-, es ejemplar la experiencia de respeto y cumplimiento, los contrastes que lleva a cabo el Legislador y el Ejecutivo, así como la inteligente y leal supervisión realizada por sus jueces. Todo ello ha hecho que el impacto de la Ley de Derechos Humanos impregnara todo el sistema jurídico del Reino Unido. Si no faltan Estados que con frecuencia firman sin saber del todo a que se comprometen, el Reino Unido sólo firma aquello que sabe que puede cumplir, como en efecto hará concienzudamente ${ }^{43}$.

A ese carro se sube a última hora Polonia. No logro entender por eso, como no sea a efectos propagandísticos, o de lavar su mala conciencia, por qué Polonia hace luego una Declaración a título individual, la número 62, referida directamente al Protocolo 30, en la que se afirma literalmente:

"Polonia, teniendo presente la tradición del movimiento social "Solidaridad" y su notable contribución a la lucha por los derechos sociales y del trabajo declara que respeta plenamente esos derechos, según se establecen en el

42 En el Preámbulo del Protocolo número 30 que se comenta, las Altas Partes Contratantes se cuidan de recalcar que lo establecido en el mismo no afecta a los demás Estados miembros, ni afecta a los dos Estados referidos más allá de los aspectos expresamente mencionados.

43 Sin que sea ocioso recordar que en unos cuantos casos bien significativos la jurisprudencia de Estrasburgo ha rectificado instituciones jurídicas británicas bien arraigadas. Baste recordar lo que significaron sentencias como la "Sunday Times" (prohibición de comentar asuntos sub judice), "Campbell y Cosans" (castigos corporales en las escuelas), "Malone" (escuchas telefónicas policiales), "Abdulaziz, Cabales y Balkandali" (extranjería), o "McCann" (uso de las armas de fuego). 
derecho de la Unión Europea, y en particular los que se reafirman en el título IV de la Carta de los Derechos fundamentales de la Unión Europea”.

¡No me compliquen la vida con los derechos sociales - vienen a decir- pero eso sí, nosotros somos más que nadie, y ahí está el ejemplo del sindicato Solidaridad! El comportamiento no parece muy serio.

C). Hay otra Declaración de Polonia a título individual, la número 61, que va en sentido muy diferente. En dicho Estado, a diferencia de la tónica general en la mayoría de países europeos, se han dejado sentir algunas voces oficiales contrarias al reconocimiento de los derechos de los homosexuales. De hecho Polonia ya ha recibido algún varapalo del Tribunal Europeo de Derechos Humanos en relación con ese problema. Como si que quisiera mantener firme en sus trece, se despacha la República con esta Declaración, que expresamente no da claves, pero que no es difícil interpretar a la vista de la reciente historia:

"La Carta no afecta en modo alguno al derecho de los Estados miembros a legislar en el ámbito de la moral pública, del derecho de familia, así como de la protección de la dignidad humana y del respeto de la integridad humana física y moral”.

¡Poco dice a favor de Polonia este texto! Conviene recordar en todo caso, que diga lo que diga esta Declaración como intentando puntualizar la Carta -más adelante, al estudiar su contenido se aludirá a algún mandato que incide aquí de lleno-, Polonia se ha vinculado expresamente al CEDH y es bien sabido como la jurisprudencia de Estrasburgo es inequívoca en el sentido de no justificar ni condenas ni traros discriminatorios por el mero hecho de la condición homosexual. Aunque la calculada vaguedad de la Declaración pueda pretender ir más lejos y, aparte la cuestión de la homosexualidad -tanto su simple asunción y reconocimiento como la regulación de la convivencia formal, bajo cualquier modalidad de unión como, incluso el matrimonio-, se estaría tomando postura también en relación con el aborto. 
D). Algo más enigmático parece, al menos a los que no están impuestos en el sistema comunitario hasta que se contrastan los datos, el Protocolo 34 referido a Irlanda, en el sentido de que los Estados firmantes asumen que ninguna disposición de los Tratados "afectará a la aplicación en Irlanda del artículo 40.3.3 de la Constitución irlandesa”. Dicho precepto, añadido en 1983, es el que garantiza "el derecho a la vida del concebido no nacido".

E). Una última referencia me lleva a la Declaración número 53, firmada por la República Checa. Recuérdese que cuando ya se había superado el chantaje de los irlandeses -a la hora de ratificar el Tratado de Lisboa, un primer referendum fallido, que hubo que repetir, con la consiguiente pérdida de tiempo y iquién sabe cuanto nos costó!-, cuando ya todo parecía estar a punto para que entrara en vigor del TL, a última hora, el Presidente de la República Checa, en una maniobra impresentable, cuando ya el Parlamento había aprobado la ratificación, y el Tribunal Constitucional la había dado por buena, puso en práctica un nuevo chantaje, rechazando insolentemente estampar su firma, desde el argumento de que el TL implicaba un sensible debilitamiento de la soberanía del Estado. Al final, los buenos oficios consiguieron que se levantara el bloqueo. En este contexto, la Declaración 53 no es demasiado original pues vuelve sobre cosas que ya han sido dichas una y otra vez, como que "la Carta no amplia el ámbito de aplicación del derecho de la Unión y no crea ninguna competencia nueva para la Unión. La Carta no reduce el ámbito de aplicación del derecho nacional y no limita ninguna competencia actual de las autoridades nacionales en este ámbito”, insistiéndose también en el respeto del principio de subsidiariedad. La Declaración como tal no tendría mayor fuerza jurídica. Pero recuérdese que de la maniobra formaba parte, como única manera de superar el bloqueo, y en el último momento, de un acuerdo de los Jefes de Estado y de Gobierno, en el Consejo Europeo de 29 y 30 de octubre de 2009, por el cual, se aprovecharía la primera reforma que hubiera de los Tratados, para añadir un nuevo Protocolo, por el cual, los efectos que el Protocolo 30 predicaba de Polonia y del Reino Unido, se proyectarían también a la República Checa ${ }^{44}$.

$44 \quad$ El Acuerdo incluía un proyecto de Protocolo, cuyo artículo 1 disponía: "El Protocolo número 30 sobre la aplicación de la Carta de derechos fundamentales de la UE a Polonia y al Reino Unido se aplicará a la República Checa”. Se contemplaba también la modificación de distintas expresiones del Protocolo 30 para que reflejaran la nueva situación 
45. Con esta referencia se concluye el largo periplo que ha sido preciso recorrer para ver como iba cobrando vida la declaración de derechos que hace años auspiciara el Proyecto Spinelli, y a la que tantos habían dedicado sus esfuerzos e ilusiones. Trayecto largo, en efecto, y zigzagueante, testimonio tantas veces del empuje de los grandes europeístas o de las pretensiones de intereses pequeños y mezquinos. Pero no hay que escandalizarse por ello ni tampoco, por supuesto, por las excepciones que han sido reconocidas. Siempre ha sido así la historia de los avances europeos. Y el que la Carta haya llegado donde ha llegado, aún con todas sus limitaciones, me parece un avance manifiesto a pesar de todos los pesares, a pesar de tanta demora que no se entiende. Representa mucho en el terreno de lo simbólico -tan útiles y necesarios los símbolos en el ámbito de la Unión Europea-, pero también en el de la operatividad jurídica. Lo importante es, sin duda, que la Carta haya entrado en vigor y pueda comenzar a surtir efectos. En cuanto a las "matizaciones" a que acabo de referirme, habrá que ver en qué quedan en la práctica, conocida la decidida línea del Tribunal de Justicia de intentar a toda costa que el Derecho comunitario prevalezca y se aplique. Quedamos así en puertas para pasar a analizar cual es el contenido de la Carta y de qué manera proyecta su eficacia.

\section{XX. ¿QUÉ ES LA CARTA?}

46. De manera que, como se decía, al mismo tiempo que entraba en vigor el Tratado de Lisboa el pasado uno de diciembre de 2009, lo hacía la Carta, con valor equivalente a los Tratados, Obviamente se trata de un instrumento jurídico de la Unión para la Unión, sin perjuicio de que, como se precisará enseguida, proyecte también sus efectos, en gran medida, a los sistemas jurídicos de los Estados miembros. En virtud de la expresa remisión que hace el artículo 6.1 del Tratado de la Unión Europea, la Carta se incorpora al ordenamiento jurídico comunitario -o, al acervo comunitario, si se quiere utilizar la expresión consagrada-, con igual valor que los Tratados, es decir, como norma de rango superior que, por ende, deberá ser tenida en cuenta y respetada por los “actos jurídicos de la Unión”, contemplados en los artículos 288 y siguientes del Tratado de Funcionamiento de la Unión Europea. 
Desde el punto de vista de su naturaleza jurídica, es una figura atípica. No encaja, obviamente, en ninguno de los "actos jurídicos" regulados en los citados artículos 288 y siguientes TFUE, como son los reglamentos, las directivas, etc. En puridad, tampoco es un "tratado", dado que el actual sistema constitucional de la Unión se refiere, con pretensión de agotar la lista, a dos únicos Tratados, de igual valor ambos, el TUE y el TFUE (así lo expresan inequívocamente el artículo 1, párrafo 3, de aquél, y el 1.1 de este último, redactados ambos en términos casi coincidentes). De hecho, el "instrumento" Carta, siendo algo diferente, tiene vocación de aproximarse a los tratados. Recuérdese que el Proyecto de Tratado estableciendo una Constitución para Europa la incluía en su seno, sin más distingos, como Parte II. En Lisboa se ha abandonado tal criterio - no se ha incluido, queda como una pieza separada-, pero la Carta ha sido expresamente modificada por el $\mathrm{TL}^{45}$, como se ha señalado, tanto de forma directa en su texto, como de manera indirecta a través de los Protocolos. Entiendo por lo mismo que su entidad jurídica es "equivalente" a la de los Tratados, lo que quiere decir que su consistencia o su alteración, cuando proceda, ha de seguir el mismo curso que los Tratados.

\section{LA PRESENTACIÓN DE LA CARTA}

47. La Carta, inspirándose en la tradición de las declaraciones de derechos, es un documento intencionadamente breve, que consta de un Preámbulo de siete párrafos y de 45 $\operatorname{artículos}^{46}$ : más breve que el CEDH (59 artículos, eso sin contar los Protocolos Adicionales), algo más extensa que la DUDH (30 artículos) y que más que triplica la famosa Declaración de Derechos del Hombre y del Ciudadano (con 17) o la Declaración de Derechos del Buen Pueblo de Virginia de 1776 (con sólo 16). Bien es verdad que con el transcurso del tiempo se han ido añadiendo nuevas aspiraciones, lo que por fuerza repercute en la extensión. La brevedad, connatural a las declaraciones de derechos, responde intencionadamente a la aspiración de conseguir un texto asequible, expresivo y elegante, que sea fácilmente retenible, para que así pueda ser constantemente tenido en cuenta. Bien gráficas resultan las palabras del Preámbulo de la

45 También lo hubiera sido de haber salido adelante el Tratado estableciendo una Constitución para Europa, como se indicó.

46 Dejo ahora de lado el necesario complemento de las "Explicaciones", como se indicó. 
Declaración de Derechos del Hombre y del Ciudadano: “con la intención de que esta Declaración constantemente presente para todos los miembros del cuerpo social les recuerde sin cesar sus derechos y deberes”. En sentido parecido, muchos años después, la DUDH de Naciones Unidas, desde su aspiración a ser "universal" y no ya el documento de un solo Estado, se marcaba similar propósito: "a fin de que tanto los individuos como las instituciones, inspirándose constantemente en ella, promuevan, mediante la enseñanza y la educación, el respeto a estos derechos y libertades".

De modo que, aspiración a conseguir un texto completo y asequible, sin olvidar el propósito de alcanzar un texto hermoso en su expresión, que por su fuerza inspire respeto. En la misma dirección, el Preámbulo de la DUDH depara en bandeja la sugerente idea de hacerlo llegar a los ciudadanos a través de la educación: filosofía de compleja y lenta realización pero, en puridad, la manera más efectiva de que una idea o una norma lleguen a calar. Por lo que habrá que instar a las autoridades educativas para que en la escuela y demás centros docentes se preste a la Carta la atención que merece, lo mismo que habrá que incentivar a maestros y profesores para que se apliquen en la tarea. No menos útil sería que los poderes públicos e instituciones -como los "Defensores del Pueblo" de todos los niveles-, pero también fundaciones, asociaciones y, sin falta, la prensa, se cuidaran de propagar el texto y hacerlo asequible.

48. Leyendo la Carta con detenimiento, yo no estoy seguro de que la redacción haya alcanzado el punto de tensión y hermosura que sería deseable. Bien es verdad que, en el presente, nos movemos con un inconveniente insuperable: las antiguas declaraciones, como Virginia, o la de la Revolución Francesa -no digamos los precedentes ingleses- eran textos, por así, decir unitarios, en los que coincidían autores y redactores. Ahora, en cambio, como es usual en la UE, el texto que regirá, tras la aprobación formal lo fijan los traductores para que así circule en las numerosas lenguas oficiales. Y ya se sabe que hay traductores muy buenos pero no será extraño que los haya menos buenos, o que ese día no hayan estado demasiado inspirados ${ }^{47}$.

47 En una comparación rápida, me da la impresión de que el texto oficial de la Carta en español -tal como lo publica la L O. 1/2008, BOE del 31 de julio de 2008, que dice transcribirlo del DOUE de 14 de diciembre de 2007-, sigue muy de cerca la versión francesa. Yo no sé, por ejemplo, si en el artículo 8 es mejor hablar, como se hace, de "protección de datos de carácter personal", o, simplemente, de "datos personales". El importante apartado 3 del 


\section{XXII. ¿RESULTA ÚTIL LA CARTA?}

49. Convendrá recalcar un aspecto, obvio por lo demás: la Carta es hoy guía decisiva en materia de DDFF como codificación y resumen de las actuales aspiraciones, por lo que desempeña un destacado papel programático lo mismo que cubre a la perfección la vertiente de lo simbólico. A ello habrá que añadir algo hoy sumamente importante: con las declaraciones de derechos ha sucedido lo mismo que con las constituciones, que han superado su etapa de meros documentos programáticos para pasar a ser consideradas también como normas jurídicas vinculantes $^{48}$. O lo que es lo mismo, derecho positivo, muy elevado en la jerarquía de normas, a tener en cuenta inexcusablemente por los aplicadores jurídicos.

$\mathrm{Al}$ enfrentarnos directamente con la Carta surge un importante interrogante que deberá ser abordado sin falta. Se dijo que venía en gran medida a aunar y reunir mandatos que ya estaban en vigor, bien que dispersos a lo largo del ordenamiento comunitario. Se destacó asimismo el interés por recalcar que la Carta no creaba competencias nuevas a favor de la Unión. Por eso, la pregunta pendiente versa sobre la utilidad de la Carta: ¿Sirve ésta para algo? ¿Añade algo nuevo? $\mathrm{O}$, incluso, si los mandatos ya estaban en el ordenamiento jurídico, ¿era necesaria?

\footnotetext{
artículo 5 prescribe que "se prohíbe la trata de seres humanos": ¿no sería mejor decir "de personas?". En cambio, ¿Toda persona tiene derecho a la educación", como dice el artículo 14, o mejor "todos tienen"? En ese mismo artículo, después de afirmarse el derecho, el apartado 3 prescribe que "este derecho incluye la facultad de recibir gratuitamente la enseñanza": no tengo claro que el verbo incluir sea el más adecuado. Un último ejemplo de un ejercicio que sería interminable y en el que caben sin duda muchas alternativas: no sé si el texto del artículo 9 es el más elegante posible, cuando dispone que "Se garantizan el derecho a contraer matrimonio y el derecho a fundar una familia según las leyes nacionales que regulen su ejercicio".

Concluyo invitando al lector a que reflexione por su cuenta. A lo mejor es posible, si un día se va a reformar algún aspecto de la Carta, que desde la sociedad civil se sugiera un texto especialmente cuidado y atractivo.

${ }_{48}$ Recuérdese el ya clásico trabajo de Eduardo GARCÍA DE ENTERRÍA, La Constitución como norma y el Tribunal Constitucional, numerosas ediciones desde la primera de 1981. Por mi parte, recordando las aportaciones de Don Nicolás Pérez Serrano, he insistido en la superación del carácter programático de las declaraciones de derechos para cobrar auténtica fuerza normativa, en mi trabajo, El orden europeo e interno de los derechos fundamentales y su protección jurídica, págs. 428 y sigs.
} 
Hay en el propio texto de la Carta, en el Preámbulo un párrafo por demás interesante a la hora de enfrentarse con su contenido. Me refiero al párrafo quinto que transcribiré en la redacción original, descartando ahora la frase final de ulterior incorporación. Dice así:

"La presenta Carta reafirma, dentro del respeto de las competencias y misiones de la Unión, así como del principio de subsidiariedad, los derechos que emanan en particular de las tradiciones constitucionales comunes a los Estados miembros, del Convenio Europeo para la Protección de los Derechos Humanos y de las Libertades fundamentales, las Cartas Sociales adoptadas por la Unión y por el Consejo de Europa, así como de la jurisprudencia del Tribunal de Justicia de la Unión Europea y del Tribunal Europeo de Derechos Humanos”.

50. Se explica bien claramente el proceso, el tan diverso origen de lo que se ha recopilado, a la par que el párrafo puede entenderse como testimonio de reconocimiento y homenaje a las fuentes originarias, a las tradiciones constitucionales comunes a los Estados miembros, a la jurisprudencia del Tribunal de Luxemburgo y a la del de Estrasburgo, al CEDH, etc. Pero lo que eran principios generales del derecho, préstamos ajenos que servían de orientación, decisiones jurisprudenciales dispersas o, directamente, normas de otros ordenamientos jurídicos, con las dificultades inherentes a la hora de su concreta aplicación jurídica, ahora se codifican, se reúnen con cuidado en un único texto, al que se dota de unidad y coherencia, y del que se predica sin reservas el carácter normativo del más alto rango. Se ha producido, creo, una encomiable concreción. Ha nacido una norma nueva, por más que algunos de sus contenidos ya estuvieran en vigor. Pero otros, no. Cierto, que no pocos de esos contenidos, como se dijo, estaban, bien que dispersos, a lo largo de los Tratados, a lo largo de los repertorios jurisprudenciales, pero otros, no. En concreto, por ejemplo, del $\mathrm{CEDH}$, que había servido en ocasiones para extraer principios generales del derecho, o de "canon de respeto" ${ }^{49}$, en principio se puede decir que, aunque lo fuera para los Estados miembros, no era un texto directamente aplicable a la Unión Europea. Pues bien, la Carta abandona ese método de referencias indirectas y es así como, de hecho, incorpora y Recuérdese el artículo 6.2 TUE tal y como se introdujo en 1992, y al que más arriba nos referimos
resaltando las limitaciones de la operación. 
transcribe los contenidos más destacados del Convenio y de algunos de los Protocolos. Lo mismo que transcribe e incorpora significativas aportaciones jurisprudenciales. A la vista de todo ello, la idea que quiero recalcar es la de que este breve texto, con su coherencia y su lógica -así como con sus limitaciones, a alguna de las cuales ya se aludió-, se presenta como una norma indudable y clara, a cuyos mandatos quedan inequívocamente vinculados todos los órganos de la UE. Por mucho que se insista en que no atribuye nuevas competencias a la Unión, resulta indudable que, desde un punto de vista normativo, viene a innovar, y no poco.

En este sentido, no es sólo el hecho, que hoy parece imprescindible, de saciar la vieja aspiración comunitaria de lograr una declaración de derechos propia, como quedó apuntado, sino que resulta de enorme utilidad esta codificación de derechos, tan innovadora a la par. De ahí mi opinión de que la Carta significa un gran paso, al margen de que se pudiera aspirar a más en cuanto alguno de los contenidos. Lo decisivo es que queda consagrada la declaración de derechos que la UE se ha dado a sí misma.

En la vertiente más exterior y superficial de lo que hoy sea la UE, al contemplar su papel en el universo de la globalización, bien presentes y arraigadas por doquier las situaciones de desconocimiento y desprecio de los derechos fundamentales, me resulta muy positivo que este "espacio de justicia y libertad" que se ha comprometido a ser la UE desde sus orígenes, pueda brindarse a sí misma, pero también a los demás, irradiándola por doquier, esta moderna declaración de derechos que, aparte de servir de autovinculación, se ofrece como don y propuesta a disposición de quien quiera utilizarla. Aparecerá así, sin falta, la importante vertiente de lo simbólico, que antes se quiso resaltar. Destacable en lo que concierne a los ciudadanos europeos pero también como modelo válido a proyectar sobre otros territorios Lo que comporta el compromiso de los juristas de la Unión de vigilar por que la Carta se respete, denunciando cualquier desfallecimiento, exigiendo su plena virtualidad así como la realización de las políticas necesarias para afianzarla, pero a la par, el compromiso de tratar de hacer que se conozca en territorios y en sistemas alejados del estándar que la Carta representa. Es decir, que harían bien los responsables de la UE en cuidar la difusión de la Carta en los más diferentes idiomas y aprovechando cualquier oportunidad propicia. 


\section{XXIII. ¿ES CONVENIENTE QUE LA UNIÓN EUROPEA SE} ADHIERA AL CONVENIO EUROPEO DE DERECHOS HUMANOS?

51. Una nueva reflexión al hilo de lo anterior. Ya se cuenta con una declaración de derechos propia. Cuando alcanzar tal meta parecía algo muy alejado, en la ya larga evolución histórica, se barajó con frecuencia, como aspiración ideal, la de que las Comunidades, luego la Unión, reconocieran de manera formal y expresa el Convenio Europeo de Derechos Humanos. Era lo que había, lo que ya estaba hecho, muy valorado además por su calidad. Algo se dijo al respecto al ir detallando alguno de los pasos históricos, señaladamente al comentar las propuestas del Proyecto Spinelli. Recordaré incluso la sensación de abatimiento que sentimos no pocos estudiosos preocupados por esta materia, cuando el TJCE, en su conocido Dictamen de 28 de marzo de 1996, nos sorprendió con aquel jarro de agua fría al determinar en conclusión que, al margen de deseos y aspiraciones, el sistema constitucional de las Comunidades no contemplaba la posibilidad de suscribir el Convenio. Instrumento, por lo demás, pensado para el control de los Estados, cuando las Comunidades -o, aún hoy, la Unión- para nada se asemejan a un Estado.

Curiosamente, esa oscilante aspiración de si se asumía o no el Convenio, cristalizó, en el mismo momento en que se consagraba la Carta, en el Proyecto de Tratado estableciendo una Constitución para Europa, en una importante afirmación -artículo I.9.2-, que el TL ha llevado literalmente al artículo 6.2 TUE, como antes se recordó, en el sentido de que,

"La Unión se adherirá al Convenio Europeo para la Protección de los Derechos Humanos y de las libertades fundamentales. Esta adhesión no modificará las competencias de la Unión que se definen en los Tratados”. 
¡Compromiso inequívoco de que la Unión se vincule con el CEDH! Con lo que se apuesta por un sistema de doble sometimiento, a la Carta y al Convenio ${ }^{50}$, en una línea que yo mismo he analizado en alguna otra ocasión, cuando he hablado de "vías concurrentes para la protección de los derechos humanos" $"$.

52. Esta línea de concurrencia de los dos instrumentos ha suscitado ya algunas reacciones al objeto de ajustar el sistema jurídico y hacer funcional la convivencia de ambos textos. Referiré así tres respuestas que se encaminan directamente al objetivo señalado.

A). Cuando se retocó la Carta con motivo de la Constitución, desde la idea de que ambos sistemas tendrían que convivir, al originario artículo 52 se le añadió un apartado tercero, que ahora sigue formando parte del texto finalmente aprobado, en estos términos:

"En la medida en que la presente Carta contenga derechos que correspondan a derechos garantizados por el Convenio Europeo para la Protección de los Derechos Humanos y de las Libertades Fundamentales, su sentido y alcance serán iguales a los que les confiere dicho Convenio. Esta disposición no obstará a que el Derecho de la Unión conceda una protección más extensa”

Se apuesta por consagrar la equiparación, intentando adelantarse a desavenencias o a interpretaciones diferenciadoras. Ello, a la par que se reconoce que es como si el correspondiente precepto del Convenio hubiera penetrado en la Carta.

B). Pero el Convenio es un texto elaborado por el Consejo de Europa, tiene un "dominus". Bien está que los textos prestigiosos sean copiados o recibidos ${ }^{52}$, pero hay una reglas de buen entendimiento y de cortesía, aparte de que si efectivamente se pretende entrar en el sistema, habrá que contar necesariamente con quien lo gestiona y administra, pues alguna adaptación será preciso realizar. Es de destacar por eso que a la par que la UE adaptaba su sistema

50 Véase José Antonio PASTOR RIDRUEJO, La Carta de Derechos fundamentales de la Unión Europea y la adhesión al Convenio Europeo según el Tratado de Lisboa, págs. 3 y sigs.

$51 \quad$ Tal es el título de un libro mío aparecido en Civitas en 2006.

52 Recuérdese lo que señalo en mi trabajo, La defensa de los derechos fundamentales: tres diferentes cauces jurisdiccionales en la Constitución española, 86. 
constitucional para facilitar el ingreso en el sistema del CEDH, el Consejo de Europa aprovechaba el trámite de elaboración del Protocolo Adicional número 14 al Convenio, de 13 de mayo de 2004, introduciendo reformas de peso en el funcionamiento del Tribunal, para incluir como artículo 59 la previsión de que "la Unión Europea puede adherirse a la presente Convención”. El Protocolo $14^{53}$ había sido bloqueado de forma muy desleal por Rusia, pero al final, tras diversos pasos adicionales, consiguió entrar en vigor. Diligentemente, ambas partes han dejado preparado el terreno desde un punto de vista formal para cuando la Unión decida incorporarse al CEDH.

C). Si se da dicho paso habrá antes que introducir algún ajuste funcional. De ahí que el TL, a la par que se introducía el apartado 2 del artículo 6 TUE, que venimos glosando, se aprobaba el Protocolo número 35 tratando de predeterminar el contenido del instrumento de adhesión. Se parte de que habrá "un acuerdo", y este acuerdo, que obviamente puede tener muchos contenidos, es el que intenta predeterminar el Protocolo. Se pretende, ante todo, que se preserven las características del Derecho de la Unión en lo que se refiere a "las modalidades específicas de la posible participación de la Unión en las instancias de control del Convenio Europeo", y en esta línea puntualiza el artículo 2,

"El acuerdo a que se refiere el artículo 1 garantizará que la adhesión no afecte a las competencias de la Unión ni a las atribuciones de sus instituciones. Garantizará que ninguna de sus disposiciones afecte a la situación particular de los Estados miembros respecto del Convenio Europeo, en particular respecto de sus Protocolos, de las medidas que adopten los Estados miembros como excepción al Convenio Europeo con arreglo al artículo 15 y de las reservas al Convenio Europeo formuladas por los Estados miembros con arreglo a su artículo 57”.

Téngase en cuenta, de una parte, que el CEDH se hizo pensando en controlar a los Estados, habitualmente denominados a lo largo del Convenio como "Altas Partes contratantes":

\footnotetext{
53 Puede verse sobre él, Juan Antonio CARRILLO SALCEDO, Hacia una mayor efectividad del mecanismo de garantía del Convenio Europeo de Derechos Humanos, 229 ss.
} 
los Estados son quienes participan en el Comité de Ministros, los que proponen a los jueces, etc. Pero, de otra parte, hay que considerar de manera muy especial el problema siempre latente de las relaciones entre los dos Tribunales: ¿Podrá el TEDH controlar y revisar las decisiones del TJUE? ¿Podrá tener Estrasburgo la última palabra en la interpretación del Derecho comunitario, así cuando un caso se oriente desde la perspectiva de los derechos humanos? Graves cuestiones de no fácil solución. No es ocioso advertir la tónica de respeto y cuidado mostrada en ocasiones por el Tribunal de Estrasburgo cuando ha tenido que entrar a ocuparse del Derecho de la Unión. Recuérdese el asunto "Bosphorus c. Irlanda", 30.VI.2005, en el que luce con toda claridad una tónica de autocontención. Pero no siempre ha sido así, como evidencia el asunto "Matthews c. Reino Unido”, 18.II.199954, aparte de que nada asegura qué puede suceder en el futuro. De otra parte, no es ocioso recordar, por ejemplo, que casi, casi, la mitad de los jueces del TEDH pertenecen a países que no forman parte de la UE. De ahí que resuenen siempre las advertencias que con energía recalcaba el Informe Pintasilgo, de que de ninguna manera podía tener el TEDH la última palabra en la interpretación del Derecho comunitario.

53. El caso es que se ha dejado todo a punto para que, una vez realizadas las adaptaciones oportunas, pueda la Unión reconocer la vigencia del Convenio y someterse a él formalmente. La empresa resulta ardua, sin duda, pero tal es la realidad a la que se ha llegado, inequívoca la fórmula del artículo 6.2 TUE, antes recordada. Alcanzado este punto, yo me permito plantearme un interrogante radical: ¿Es necesario o, incluso, es conveniente y oportuno, que la UE se adhiera al $\mathrm{CEDH}$ ? Conste que este interrogante me lo planteo sólo una vez que se ha producido un avance radical, tan lejos hoy la UE de aquellos momentos iniciales en que la jurisprudencia del TJCE asumió la decisión de ir destilando de las tradiciones constitucionales de los Estados principios generales con los que resolver los casos que más chirriaban, tan lejos de cuando los Tribunales Constitucionales de Italia y Alemania retaban a la Comunidad: ¡"Mientras tanto, o, hasta tanto"!, tan lejos de cuando el Proyecto Spinelli, en 1984, proponía engancharse a lo único que entonces funcionaba que era en principio el CEDH. A lo largo de buena parte de la evolución, como antes se analizó, el Convenio Europeo era el texto puntero, el faro más luminoso

\footnotetext{
54 Que he comentado críticamente en mi trabajo, Los derechos electorales a la luz de la jurisprudencia del TEDH, 33 ss.
} 
y atractivo en materia de derechos humanos. De ahí la seducción que de manera intermitente iba produciendo. De ahí su presencia como aspiración, justificada incluso por la tardanza de la Unión en resolver el problema de una vez. Sólo el 1 de diciembre de 2009 ha podido entrar en vigor la Carta de Derechos Fundamentales de la Unión Europea. A partir de entonces, el panorama ha cambiado de manera radical, por más que no haya que olvidar los avatares que ha sido preciso superar.

Ante la nueva situación, mi postura es tajante y decidida: no tiene ningún sentido, no hace ninguna falta, no añade nada sustancioso, el que la UE suscriba el CEDH. Habría sí un cierto aspecto simbólico, el de acogerse a tan prestigiosa trayectoria, revalidando así de manera muy notable al propio Convenio, pero me da la impresión de que ese aspecto simbólico ni añade nada nuevo ni es necesario en estos momentos. Yo no lo creo ni útil ni conveniente por la serie de razones que vengo exponiendo y que sintetizaría de la siguiente manera.

A). La Unión ya tiene su propia declaración de derechos, tanto tiempo auspiciada y al fin conseguida.

B). Pero es que, además, como se ha recalcado, la Carta ha incorporado directamente los preceptos más destacados del Convenio y de los Protocolos. El Convenio, fragmentado y a trozos, ha penetrado de lleno en la Carta.

C). Además la Carta, al ser más moderna, ha podido incorporar DDFF hoy socialmente reclamados que no estaban en el Convenio ni habían llegado a los protocolos. Es decir, es un texto moderno y actualizado.

D). Por si hiciera alguna falta -lo que, a simple vista, no parece probable dada la expresa incorporación referida-, no hay que olvidar que el TUE, como se recordó, de alguna manera da entrada al Convenio, cuando el artículo 6.3 puntualiza que los DDFF que garantiza el Convenio y los que son fruto de las tradiciones constitucionales comunes a los Estados, "formarán parte del Derecho de la Unión como principios generales”. El mantenimiento hoy de este precepto, en lo 
referente al Convenio, significa una clara redundancia: esos DDFF se han codificado hoy y figuran como norma escrita en la Carta; de modo que van a quedar en el limbo prestos a ser convertidos en principios generales del derecho.

E). Sin olvidar además que el $\mathrm{CEDH}$ ha sido aceptado por todos y cada uno de los Estados miembros de la UE -sin perjuicio de las reservas que también trataría de salvar, en su caso, el Protocolo 35-, de forma que, como regla, ha pasado a formar parte del ordenamiento jurídico de cada uno de ellos y a incrementar así también la corriente de las tradiciones constitucionales comunes.

F). Si algún día se quiere acrecer el acervo de DDFF de la Carta o superar algunas restricciones -bien sabemos que la historia no se detiene y que periódicamente se dejan sentir nuevas necesidades o maduran otras ya presentes-, se puede utilizar el trámite de reforma de los Tratados que de vez en cuando se pone en marcha. Esperemos que sea para avanzar y no para dar pasos atrás.

G). Desde el punto de vista de la calidad del ordenamiento jurídico, vertiente tan destacada y tan digna de atención, creo que es mucho mejor el sistema de un único texto, una vez que la codificación haya resultado suficientemente amplia y satisfactoria, como es el caso de la Carta. Mejor, apoyarse en un único texto que fiarse de la aparente abundancia de dos textos casi coincidentes superpuestos. Edificar el sistema de derechos fundamentales de la UE sobre la Carta, tal como ha resultado, ahorra energías y trabajos, por lo que resulta ventajoso.

H). La única carencia que originaría el abandono del Convenio sería la de no poder contar con pieza tan cualificada, y especializada, como el TEDH Es un argumento de peso, pero también es cierto que ya hay un Tribunal, igualmente cualificado, garante del Derecho comunitario, como es el TJUE, y hoy no cabe duda de que la Carta es Derecho comunitario. Se consagraría así -cosa que ya lo es-, como garante del Derecho comunitario, cualquiera que fuera la especialidad, también, por tanto, en el ramo de los derechos fundamentales. Luego, siempre bajo su suprema jurisdicción, para el día a día, están listos para actuar los órganos jurisdiccionales 
de los Estados miembros, pues para eso está también "la cuestión", del artículo 267 TFUE. Con esta fórmula se evita el delicado problema de decidir si el Tribunal de Estrasburgo va a tener o no supremacía sobre el Tribunal de Luxemburgo. Por otro lado, no es difícil reconocer que el peso de la jurisprudencia del Tribunal Europeo de Derechos Humanos en lo concerniente a la interpretación del CEDH va a seguir siendo grande, dado su prestigio y solidez. De esta manera, y como tantas veces lo ha sido, podrá continuar siendo guía segura cuando el Tribunal de Justicia de la Unión Europea tenga que resolver algún problema sobre preceptos de la Carta que sean transcripción de preceptos del Convenio. Pero, en tal caso, se estaría ante las normales relaciones entre dos Tribunales equiparables, sin tener que plantear problema alguno de superioridad estructural.

I). Queda un último problema por resolver, dada la rígida expresión que ha impuesto el Tratado de Lisboa al artículo 6.2 TUE -en puridad, ya estaba en el proyecto de Constitución, artículo I.9.2-, cuando expresa que "La Unión se adherirá al Convenio”. ¡Tantas cosas que abordar a la hora de intentar que los afanes de la Constitución, tan necesarios, no cayeran en el vacío, y en este punto, acaso secundario, se tiró por la línea fácil de transcribir sin más! Pues nada difícil hubiera sido intentar otra solución o, incluso, abandonar la idea. No conozco el debate al respecto, ni sé si lo hubo, y no me aventuraré a criticar la fórmula. ¿Qué hacer? No parece muy correcto recomendar el incumplimiento de un mandato. Me atreveré por eso a decir, en línea con mi argumento de que no tiene sentido que la Unión suscriba el Convenio, que como no hay un plazo, aparte de que el Protocolo 35 presupone unas negociaciones que pueden ser delicadas y complicadas, que lo correcto podría ser tomarse un plazo de reflexión para ir madurando la idea y aclarar qué es lo que conviene.

\section{XXIV. ¿QUIÉNES SON LOS DESTINATARIOS DE LA CARTA?}

54. Una Carta de la Unión Europea para la Unión Europea, se decía. Pero no es sólo eso, hay algo más. Corresponde ahora tratar el problema de a quién se aplica la Carta: en puridad, 
¿quiénes son los destinatarios de la misma? ${ }^{55}$ Como declaración de derechos de la Unión Europea, se diría que, obviamente, la Carta afecta a la Unión Europea, es decir, señaladamente, a sus órganos e instituciones. Es Decir, una Carta de la Unión Europea para la Unión Europea. Aunque hay que advertir inmediatamente que la Unión Europea no nos es algo ajeno, en cuanto bien sabemos de que manera todo nuestro entorno vital, en lo jurídico pero también en lo económico y en lo social, está intensamente predeterminado por las opciones que adopta la Unión Europea. Pero aunque partamos del aserto de que se trata de documento que afecta a la Unión Europea, ello es cierto, pero es sólo parte de la verdad. En efecto, el título último de la Carta, el VII, el que contiene las "Disposiciones generales", aborda en el primero de sus artículos, el 51, el problema del "Ámbito de aplicación”. Son claras sus primeras palabras: "Las disposiciones de la presenta Carta están dirigidas a las instituciones, órganos y organismos de la Unión”. Por de pronto queda consignado el efecto obvio, de manera que todos los derechos, libertades o principios proclamados estarán vinculando a toda la organización interna del gran complejo europeo, ya sea el Parlamento o el Tribunal de Justicia, ya el Consejo Europeo, el Consejo o la Comisión, pero lo mismo las Agencias o cualesquiera instituciones, tanto como organizaciones, del mismo modo que las personas titulares de las mismas en cuanto actúen a ese título. Tal sería el efecto normal, que por lo mismo no debería ofrecer mayores particularidades, aunque sin duda sea un compromiso que haya de requerir esfuerzos y adaptaciones.

55. Pero la cosa no queda ahí, y ahora vendría lo que más puede interesarnos pensando en el sistema jurídico español. Porque el artículo 51.1 citado, indica algo más. Será lo mejor transcribir el apartado íntegro:

"Las disposiciones de la presente Carta están dirigidas a las instituciones, órganos y organismos de la Unión, dentro del respeto del principio de subsidiariedad, así como a los Estados miembros únicamente cuando apliquen el Derecho de la Unión. Por consiguiente, éstos respetarán los derechos, observarán los principios y promoverán su

55 En este epígrafe sigo muy de cerca lo que expresaba en mi reciente trabajo, La doble funcionalidad de la Ley Orgánica por la que se autoriza la ratificación del Tratado de Lisboa (La Carta de derechos Fundamentales de la Unión Europea en el "Boletin Oficial del Estado"), págs. 143 ss. 
aplicación, con arreglo a sus respectivas competencias y dentro de los límites de las competencias que los Tratados atribuyen a la Unión”.

Es de destacar la referencia expresa a los Estados miembros. Paso así a comentar la incidencia que se incluye para cada uno de los Estados. En la tónica de interconexión de ordenamientos jurídicos propia de nuestro tiempo, es de destacar este curioso juego de espejos: la Unión decide comprometer a cada uno de los Estados miembros con el rico contenido de la Carta, aún sin olvidar que para que la Carta haya entrado en vigor la han debido aprobar todos y cada uno de los Estados miembros. Con todo, el que esta obligación de respetar la Carta se proyecte también a los Estados miembros es un dato de enorme significado, que conviene destacar, que nos concierne de lleno, y para el que hay que estar preparados. Los Estados habrán de aplicar la Carta, es decir, deberán sentirse vinculados por ella, "cuando apliquen el Derecho de la Unión”. De hecho, con esta fórmula, se está auspiciando una proyección enorme para la Carta.

Se parte del dato obvio de que, como regla y salvo excepciones, el sistema comunitario no tiene órganos periféricos de aplicación, por lo que serán los agentes de los Estados quienes deben dar aplicación al Derecho comunitario, del mismo modo que se asume que los Jueces y Tribunales internos son también Jueces del Derecho Comunitario ${ }^{56}$ : aquéllos están dando aplicación constantemente al Derecho comunitario, lo mismo que éstos lo reflejan con normalidad en sus decisiones. Lo que representa, que unos y otros, habrán de tomar inexcusablemente la Carta como motivo de referencia en cuanto estén dando aplicación al Derecho Comunitario.

56. Entiendo que cabe hacer aquí unas consideraciones acerca del interesante problema de qué haya que entender por Derecho comunitario o, con más precisión, cuando estará un Estado -sus autoridades, sus funcionarios o sus jueces- "aplicando el Derecho de la Unión”, como dice con precisión el texto de la Carta. Consideraciones que dan por sentado el criterio metodológico, de que, en el hoy y aquí, vivimos en un sistema de "interconexión de ordenamientos jurídicos". Hay una espesa red, de forma que a la hora de aplicar las normas jurídicas, se mezclan las

56 Véase Ricardo ALONSO GARCÍA, Sistema jurídico de la Unión Europea, 2010. 
nacionales genuinas con las que provienen de ordenamientos supranacionales o extranjeros, pero que cada uno de los Estados -como España, en nuestro caso-, han asumido libre e intencionadamente. Se trata de un fenómeno contemporáneo, muy vivo y de enormes consecuencias, al que ya se aludió, por lo que bastará ahora con una mera remisión ${ }^{57}$.

Se estará aplicando el Derecho de la Unión, sin duda en una serie de supuestos frecuentes y de fácil comprensión. Así, cuando cualquier operador jurídico de un Estado -pongamos por caso España-, en las circunstancias que sean, esté dando cumplimiento a las disposiciones de cualquiera de los Tratados. Por ejemplo, un Juez o Tribunal Español que haya planteado "la cuestión” del artículo 267 TFUE al Tribunal de Luxemburgo. Entra también, sin duda, el importante apartado de cuando se trate del cumplimiento de reglamentos comunitarios, de incidencia directa como es notorio. El problema es ya algo más complejo -aunque mucho más frecuente- en relación con las directivas. Pero, por de pronto, en los supuestos, sin duda excepcionales, en que no haya habido transposición y haya que dar aplicación inmediata a la directiva, estaríamos también en el caso.

Especialmente interesante resulta el supuesto habitual de que la directiva haya sido transpuesta, que nos va a deparar sin duda derecho ambivalente o de doble naturaleza: la norma resultante será inequívocamente Derecho español, normalmente la ley correspondiente, elaborada por las Cortes Generales o, en su caso, por las Asambleas Legislativas de las Comunidades Autónomas, o, eventualmente, la disposición reglamentaria promulgada por uno u otro Ejecutivo. Pero el caso es que, en tales supuestos, la norma española estará conteniendo, sin falta, Derecho comunitario. Derecho español, promulgado en España por los órganos que tienen la competencia normativa, y de acuerdo con los criterios propios, pero, al mismo tiempo, el contenido será, sin lugar a dudas, de Derecho comunitario. Lo que supone que los operadores jurídicos estarán dando aplicación, a la par, al Derecho español y al Derecho comunitario. Lo que exigirá, por tanto, que la norma en cuestión tenga que ser respetuosa, sin falta, para con la Carta. Avisados quedan por tanto los operadores jurídicos nacionales de que el respeto a la Carta ha de imponerse sin excusa. De donde deriva la secuela elemental de que habrá que permitir el control a la luz de la

57 Me remito de nuevo a mi libro, La interconexión de los ordenamientos juridicos y el sistema de fuentes del
derecho. 
Carta. Supuestos de este tipo van a abrir un sinfín de oportunidades y de hecho, van a representar, una intensísima incidencia de la Carta. Que, recalco, deberá forzar a que estén muy atentos los operadores jurídicos españoles, de cualquier ámbito, sean jueces o administradores, y éstos, de la General del Estado, de la Autonómica, de la Local, o de la que sea. Es decir, que en el día a día de la aplicación del Derecho, habrá que incorporar el esfuerzo añadido de determinar si una norma española está en realidad incorporando una directiva comunitaria. El caso es que en la realidad son numerosísimas las normas españolas cuyo contenido es inequívocamente -al menos en su gran mayoría- Derecho comunitario. Y esa gran mayoría de Derecho comunitario puede estar mezclada con normas genuinas de Derecho español, con una clara tendencia a la simbiosis, o a la creación de zonas de mezcla, con la consecuencia de una poderosa atracción a la hora de dar aplicación a las exigencias de la Carta. Situación evidente a lo largo de todo el ordenamiento jurídico y afectando a las más diversas ramas y disciplinas, desde el Derecho mercantil al Derecho penal. Hoy, cumplidos los veinticinco años del ingreso de España en las Comunidades Europeas, el panorama jurídico español rebosa Derecho comunitario por todos los costados. Sin salir del ámbito del Derecho administrativo, en cualquier sector que nos detengamos, no sólo de la parte especial sino también de la parte general, resultan evidentes las exigencias y las soluciones comunitarias. Pienso en la intensísima presencia cotidiana de la legislación de contratos administrativos, lo que ahora, desde una mayor incidencia, contempla la Ley de Contratos del Sector Público, la 30/2007, de 30 de octubre ${ }^{58}$, Ley cuya incitación europea no alcanza a justificar

58 Especialmente significativos me parecen los dos párrafos iniciales de la Exposición de Motivos de dicha Ley: "Desde la adhesión a las Comunidades Europeas, la normativa comunitaria ha sido el referente obligado de nuestra legislación de contratos públicos, de tal forma que, en los últimos veinte ańos, las sucesivas reformas que han llevado desde el Texto Articulado de la Ley de Bases de la Ley de Contratos del Estado hasta el Texto Refundido de la Ley de Contratos de las Administraciones Públicas han tenido como una de sus principales justificaciones la necesidad de adaptar esta legislación a los requerimientos de las directivas comunitarias.

Esta Ley de Contratos del Sector Público también ha encontrado en la exigencia de incorporar a nuestro ordenamiento una nueva disposición comunitaria en la materia el impulso primordial para su elaboración. Las Directivas 92/50/CEE del Consejo, de 18 de junio de 1992, sobre coordinación de los procedimientos de adjudicación de los contratos públicos de servicios; 93/36/CEE, del Consejo, de 14 de junio de 1993, sobre coordinación de los procedimientos de adjudicación de los contratos públicos de suministro; y 93/37/CEE del Consejo de 14 de junio de 1993, sobre coordinación de los procedimientos de adjudicación de los contratos públicos de obras, han sido sustituidas recientemente por la Directiva 204/18/CE del Parlamento Europeo y del Consejo, de 31 de marzo de 2004, sobre coordinación de los procedimientos de adjudicación de los contratos públicos de obras, de suministro y de servicios, disposición que, al tiempo que refunde las anteriores, introduce numerosos y transcendentales cambios en esta regulación, suponiendo un avance cualitativo en la normativa europea de contratos". 
la zafiedad del legislador español: el Derecho comunitario se puede transcribir con sistema, con limpieza de conceptos, con cierto respeto también a la experiencia acumulada y en cambio el dato real es en este caso el de que por su confusión la nueva ley de contratos -que ha ampliado enormemente su campo de aplicación- parece hecha aposta para complicar la vida de las corporaciones y para aumentar la litigiosidad, como si quisiera echar una mano a los abogados en estos tiempos de crisis... Abundante presencia comunitaria igualmente en tantas de las normas que jalonan el ordenamiento del medio ambiente, desde la evaluación de impacto, la prevención y control integrados de la contaminación, la responsabilidad medioambiental, la información y transparencia, a la regulación del medio ambiente sonoro, la que se conoce como Ley del Ruido, la 37/2003, de 17 de noviembre ${ }^{59}$. Sin duda, el Derecho ambiental español-lo mismo que muchos otros sectores de nuestro ordenamiento jurídico, como lo referente a la protección del consumidor $^{60}$ - va a ser, en su inmensa mayoría, Derecho comunitario. O pienso, como último ejemplo, en la incidencia sobre el régimen jurídico de las Administraciones Públicas y, en concreto, sobre el procedimiento administrativo, de la famosa Directiva 2006/123, del Parlamento Europeo y del Consejo, de 12 de diciembre de 2006, relativa a los servicios en el mercado interior, conocida usualmente como "Directiva de Servicios", que tan compleja respuesta normativa ha venido suscitando. Sin entrar en el amplio desarrollo autonómico, bastará ahora con aludir a la Ley 17/2009, de 23 de noviembre, sobre libre acceso a las actividades de servicios y su ejercicio, y, al mes siguiente, a la Ley 25/2009, de 22 de diciembre, modificando diversas leyes para adaptarlas a la Ley anterior ${ }^{61}$.

Estamos, en efecto, ante un reconocimiento paladino de que la Ley española va a ser el vehículo de una importante penetración de Derecho comunitario.

59 También en la Exposición de Motivos de la Ley del Ruido se justifica con holgura su vinculación a la normativa comunitaria, señaladamente a la Directiva 2002/49/CE del Parlamento Europeo y del Consejo de 25 de junio de 2002, sobre evaluación y gestión del ruido ambiental, la abreviadamente denominada "Directiva sobre Ruido Ambiental".

Diré lo mismo que antes: el que haya que incorporar las directivas y recibir el derecho comunitario no es excusa para no hacer una ley cuidadosa, teniendo en cuenta los numerosos destinatarios de la misma, a los que habría que facilitarles la tarea.

60 Véase Javier GUILLÉN CARAMÉS, El estatuto del consumidor.

${ }^{61}$ Véase Luis MARTÍN REBOLLO, Leyes Administrativas, 16 a edición, 441. Obviamente, la intensa incidencia de la trasposición de la Directiva así como las numerosas cuestiones que plantea están dando pié a una rica bibliografía que se enfrenta con los problemas sectoriales suscitados. Véase, por todos, el volumen colectivo dirigido por Ricardo RIVERO ORTEGA, Mercado europeo y reformas administrativas. La trasposición de la Directiva de Servicios en España, Civitas, 2009; más recientemente, Matilde CARLÓN, El impacto de la transposición de la Directiva de Servicios en el régimen de los Colegios Profesionales, 99 ss.; Belén NOGUERA DE LA MUELA, El impacto de la Directiva de Servicios sobre el sector del comercio: en especial, el caso de Cataluña, 237 ss. 
En definitiva, que por unas vías u otras, va a haber una gran copia de supuestos en los que responsables españoles estén aplicando el Derecho de la Unión, lo que conllevará la incidencia inmediata de los preceptos de la Carta que sean de aplicación en tales supuestos.

\section{LA DIVERSA DENSIDAD JURÍDICA DE LOS PRECEPTOS}

\section{DE LA CARTA}

57. Los 54 artículos de la Carta aparecen organizados en siete títulos. No hay un título introductorio o preliminar como suele ser usual, sino que se entra de lleno en la exposición de los derechos fundamentales, lo que se hace en los seis primeros títulos, dedicándose el último, el VII (artículos 51 a 54), a las reglas operativas, lo que algunos llaman los preceptos transversales, que inciden sobre todo el conjunto, como al ámbito de aplicación, los criterios interpretativos, las cautelas a la hora de la aplicación o los posibles límites a los derechos. Entre ellos se incluye una cláusula de salvaguardia, cuando el artículo 53 asegura que la Carta no puede ser interpretada como limitativa, ni en el ámbito de la Unión ni en el de los Estados, de los derechos y libertades propiciados por otras fuentes, como las Constituciones nacionales, el CEDH, el propio Derecho de la Unión o las normas internacionales.

He hablado de la diversa "densidad" jurídica de los preceptos incluidos en la Carta. Es que, en efecto, a lo largo del texto, el compromiso para la Unión o para los Estados, de una parte, o, de otra, las pretensiones a favor de los ciudadanos, se formulan de muy diferente manera. Lo que, por ejemplo, repercutirá en muy diversa medida a la hora de activar la respuesta que deba dar la Unión, o cada uno de los Estados, o, en el otro sentido, a la hora de determinar las pretensiones que puedan plantear los ciudadanos ante los jueces. Lo que digo se entenderá mejor si tomamos como ejemplo tres preceptos con bien diversa estructura. Por seleccionar un modelo clásico de precepto inmediatamente vinculante, el artículo 11 comienza diciendo que "Toda persona tiene derecho a la libertad de expresión” y continúa en la misma línea. Es un precepto tajante, terminante, que en principio no necesita de mayores concreciones: los poderes públicos deben 
saber a qué quedan comprometidos, lo mismo que los ciudadanos asumen cuales son sus opciones. Otra variante: el precepto que garantiza la "Libertad de empresa”, el 16, proclama que "Se reconoce la libertad de empresa de conformidad con el Derecho de la Unión y con las legislaciones y prácticas nacionales”. Aquí hay un principio de reconocimiento de opción, en cuanto está claro que queda reconocida la libertad de empresa, pero luego, en el terreno operativo, va a jugar ya un papel determinante "la legislación", de forma que las peculiaridades del derecho, requisitos, exigencias e, incluso, límites, otorgan un amplio margen de maniobra al correspondiente legislador nacional. Una tercera graduación podría observarse en el precepto referido a "Protección del medio ambiente", el 37, que dispone: "En las políticas de la Unión se integrarán y garantizarán, conforme al principio de desarrollo sostenible, un elevado nivel de protección del medio ambiente y la mejora de su calidad”. Si leemos superficialmente el índice de contenidos de la Carta podemos creer que en ella ha hallado cabida el "derecho a la protección del medio ambiente". En puridad, se parte de un consistente compromiso con la protección del medio ambiente, en línea con lo dispuesto en los Tratados, como asevera además la práctica cotidiana, que habrá de reflejarse a la hora de elaborar las diversas políticas concretas. Cierto que cabe que los Tribunales puedan ir preparando el salto cualitativo de alumbrar pretensiones de los ciudadanos de donde había meros mandatos a los poderes públicos ${ }^{62}$, pero a la hora de codificar la Carta, es bien poco lo que se incluye con esa redacción, sin duda intencionada. Ya quedó dicho que la materia medio ambiente, si objeto hoy del mayor interés y de certeras preocupaciones, se presenta complicada a la hora de formalizarla jurídicamente, a la hora también de comprometer a tantos Estados, con tan diversas sensibilidades y disponibilidades económicas. Y es que, como se ha recalcado, es pretensión decidida de los Estados contener el activismo judicial en determinados sectores.

62 Dos ejemplos de la experiencia del TEDH me parecen de sobra indicativos. En mi citado trabajo sobre Los derechos electorales a la luz de la jurisprudencia del TEDH, mostraba mi sorpresa y admiración por el juego que se le ha sacado al artículo 3 del Protocolo Número Uno, con su previsión de que los Estados organicen elecciones libres. En otro sentido, he destacado también el fenómeno de lo que denomino "la defensa cruzada de derechos": en efecto, aunque el derecho al medio ambiente no haya llegado ni al CEDH ni a los Protocolos, el TEDH ha sabido valerse de otros derechos garantizados para consolidar un importante nivel de protección ambiental. Véase así mi trabajo, $L a$ defensa cruzada de derechos: la protección del medio ambiente en la jurisprudencia del TEDH, 727 ss. 
He aquí por qué aludía a la diversa densidad jurídica de los preceptos. Los ejemplos ofrecidos resultan así expresivos para ayudar a calibrar los tan heterogéneos compromisos jurídicos que van a derivar de los diversos contenidos de la Carta.

\section{DERECHOS, LIBERTADES Y PRINCIPIOS}

58. La Carta ha incorporado a su vez una triple distinción -que no coincide con lo que acabo de exponer-, de cierto arraigo en la dogmática de los derechos humanos, que sirve para situar y localizar, pero que en la práctica, a no ser en lo concerniente a la justiciabilidad de la tercera categoría en contraste con las otras dos, no suele tener demasiadas consecuencias, aparte de que no siempre está claro del todo donde hay que situar cada una de las opciones. Ya destacaba como se ha insistido en diferenciar "derechos, libertades y principios" (artículo 6.1 TUE, así como en diversos pasajes de la Carta, como la frase final del Preámbulo ${ }^{63}$, o los artículos 51.1 y $52)^{64}$. Como punto de partida diríamos que los "derechos" serían los tradicionales "derechos de la personalidad", como el "derecho a la vida" (artículo 2), el "derecho a la integridad de la persona" (artículo 3), etc. Las "libertades" nos situarían ante las llamadas "libertades cívicas". La Carta ha rotulado el Título II como "Libertades": en él se incluyen, ente otras, la "libertad de pensamiento, de conciencia y de religión" (artículo 10), la "libertad de expresión y de información" (artículo 11) o, acaso, una proyección de la anterior, la "libertad de las artes y de las ciencias" (artículo 13). Los principios, como regla, no están enumerados ni designados como tales, sin perjuicio de alguna excepción, como cuando el rótulo del artículo 49 se refiere a los "Principios de legalidad y de proporcionalidad de las penas", y el artículo 52 alude en su rótulo al "alcance e interpretación de los derechos y principios", y hablará luego en el texto "del respeto del principio de proporcionalidad”. La mención, aparte de su funcionalidad, constituiría también un homenaje a la labor del Tribunal de Justicia en su pionera y nunca abandonada tarea de alumbrar principios generales del derecho comunitario de las tradiciones constitucionales de los Estados miembros. En este sentido resulta bien expresivo lo que dispone el artículo 6.3 TUE. En esta línea, la Carta va a

\footnotetext{
63 "En consecuencia, la Unión reconoce los derechos, libertades y principios enumerados a continuación".

64 Recuérdese que el título real del CEDH es el de "Convenio para la Salvaguarda de los Derechos Humanos y Libertades Fundamentales”: es decir, convivirían indistintamente y sin más precisiones, derechos y libertades.
} 
ofrecer un mandato decisivo desde el punto de vista de su régimen jurídico, cuando el artículo 52 que, como se ha referido, aborda el "alcance e interpretación de los derechos y principios", dispone en su apartado 5:

"Las disposiciones de la presenta Carta que contengan principios podrán aplicarse mediante actos legislativos y ejecutivos adoptados por las instituciones, órganos y organismos de la Unión, y por actos de los Estados miembros cuando apliquen el Derecho de la Unión, en el ejercicio de sus competencias respectivas. Sólo podrán alegarse ante un órgano jurisdiccional en lo que se refiere a la interpretación y control de la legalidad de dichos actos".

Es decir, se parte de una metodología por así decir dual: la Carta enumera de manera genérica y sin concretar un valor jurídico que luego el Legislador o el Ejecutivo, sea de la Unión sea de los Estados, habrá de desarrollar. Y sólo entonces podrá surtir efectos que incidan sobre los ciudadanos. O, dicho desde la otra perspectiva, sólo entonces los ciudadanos podrán poner en ejercicio las correspondientes funciones jurisdiccionales. Antes transcribía el precepto correspondiente a la protección del medio ambiente, el artículo 37, aunque bien se podría poner el ejemplo del precepto siguiente, el 38, sobre "Protección de los consumidores": "En las políticas de la Unión se garantizará un nivel elevado de protección de los consumidores”. Estos preceptos sustentan un compromiso primario que insta de manera genérica a abordar la materia, sin indicación de tiempo y apenas sin concreción en cuanto a los contenidos. Es un mandato que habrá que cumplir -y ahí contará la fuerza de la opinión pública, la sensibilidad y disposición de "los elegidos", etc.-, de manera que cuando aparezca la norma -o la medida- correspondiente, habrá quedado concretado el campo, clarificando los compromisos públicos, indicándole también al ciudadano cuales son sus opciones. El juez correspondiente -tal como quiere el citado artículo 52.5- no está habilitado para delimitar cual haya de ser el alcance de tal concreción. Su actuación se circunscribirá a comprobar la corrección de la aplicación de la norma de desarrollo. En el fondo, el esquema es similar al de la tercera categoría consagrada por la Constitución española en 
el Capítulo tercero del Título I ${ }^{65}$, la de los "principios rectores de la política social y económica”, en relación con los cuales el artículo 53.3 CE reclama la intermediación del legislador, a cuyo desarrollo ha de circunscribirse la eventual supervisión jurisdiccional.

Y es que, en según que materias, se ha pretendido reflejar en la Carta lo que son aspiraciones innegables de nuestro tiempo, muy presentes en la opinión pública, pero delicadas y de difícil concreción, lo que se ha traducido en un rechazo por los Gobiernos de apriorismos generales e inconcretos, muy presente siempre, como se recordó, el fantasma del activismo judicial , y de ahí que haya prevalecido la fórmula que permita definir a los Estados las cargas a que se comprometen.

\section{VISIÓN GLOBAL DEL CONTENIDO DE LA CARTA.} PRINCIPALES INNOVACIONES

59. La codificación que supone la nueva declaración de derechos va a dar cabida, de acuerdo con lo que se indicó, a los más cualificados derechos y libertades de la historia de la evolución garantista, pero con la oportunidad de incorporar las más recientes aspiraciones.

Entre aquellos arraigados, aunque sólo sea punteando el contenido del CEDH, encontraremos, además de los que ya se han mencionado, el derecho a la vida privada y familiar (artículo 7), el derecho a contraer matrimonio y a fundar una familia (artículo 9), reunión y asociación, incluidos partidos políticos y sindicatos (artículo 12), derecho a la educación (artículo 14), etc., y, por supuesto, los clásicos derecho a la libertad y a la seguridad (6), así como a las garantías penales (48 y 49) y derecho a la propiedad (17). En relación con este último, aparte de recalcar que se garantiza decididamente algo hoy tan importante como es la "propiedad intelectual" (apartado 2), aunque en España no falten las voces que "generosamente" defienden la apropiación y utilización gratuita, señaladamente a través de las oportunidades de la "red",

65 Las otras dos son, como se recordará, los derechos fundamentales en sentido estricto, contemplados en la Sección primera del Capítulo segundo, y los derechos de los ciudadanos -o derechos fundamentales no cualificadosregulados en la Sección segunda del propio Capítulo segundo, todos dentro del Título I. 
destacaré que, con un acertado tono de modernidad y precisión, se cuida de puntualizarse que lo que se protege es la propiedad de los bienes que hayan sido "legalmente adquiridos": certera previsión en un mundo en el que gracias a las facilidades de las comunicaciones, hay cualificados especialistas en el "blanqueo" de capitales ilegalmente amasados, ya sean con el tráfico de drogas, con el agio ilegal, con la corrupción política o con cualquiera de las flores similares que florecen en nuestros jardines contemporáneos.

60. Pero, obviamente, todo nuevo texto incorpora, en la medida de lo posible, las sensibilidades de su tiempo. Destacaré así la plena acogida que logra, como opción separada e independiente, el derecho a la protección de los datos personales (artículo 8). Querría también señalar en esta línea, el novedoso artículo 3, sobre "Derecho a la integridad de las personas", que al codificar la clásica regla de que: "Toda persona tiene derecho a su integridad física y psíquica" (apartado 1), precisa en el apartado 2:

"En el marco de la medicina y la biología se respetarán en particular:

a) el consentimiento libre e informado de la persona de que se trate, de acuerdo con las modalidades establecidas por la ley;

b) la prohibición de las prácticas eugenésicas, en particular las que tienen como finalidad la selección de las personas:

c) la prohibición de que el cuerpo humano o partes del mismo en cuanto tales se conviertan en objeto de lucro;

d) la prohibición de la clonación reproductora de seres humanos"

Se pone énfasis en la preocupación tradicional por la igualdad y la no discriminación, muy sensibilizadas las Comunidades desde sus orígenes por evitar la discriminación entre sexos (como lo reflejan ahora los artículos 21 y 23, fiel espejo de lo que han venido disponiendo los Tratados), aunque se refleja también la tendencia reciente, aparentemente contradictoria con lo anterior, de dedicar atención cualificada a grupos de personas especialmente sensibles, como los niños (artículo 24), las personas mayores (25), o los discapacitados (26). En esta línea, cuando el artículo 21 enumera las circunstancias que no deben dar lugar a discriminación -sexo, raza, color, 
religión, etc.- ha incorporado, tomándolo del TCE donde ya estaba, la referencia a la "orientación sexual": no discriminación tampoco a causa de la orientación sexual. Importante precisión, que llega así a una declaración de derechos, y que refleja la actual sensibilidad en relación con la homosexualidad y el deseo de superar tratamientos históricos de condena y exclusión que hoy se consideran injustificables.

61. Muy notable el conjunto de derechos que se incorporan referentes a la ciudadanía, al mundo del trabajo y de la empresa o a otras aspiraciones sociales -reflejando así la preocupación por los llamados "derechos sociales", que venían reclamándose con intensidad" ${ }^{66}$, tomados ya de los Tratados, de las Cartas Sociales o de exigencias arraigadas en el ambiente contemporáneo. Aparecen así desde las "condiciones de trabajo justas y equitativas" (artículo 31), o "prohibición del trabajo infantil" (artículo 32), a la "protección en caso de despido injustificado" (artículo 30), o a la "seguridad social y ayuda social" (artículo 34).

\section{CONTENIDOS DE LA CARTA}

62. La ordenación de los preceptos sustantivos dentro de los seis primeros Títulos se hace, con el convencionalismo inevitable, por razón de contenidos, de materias o de la metodología propia de los derechos. Valdrá la pena dedicarles una somera visión de conjunto.

\section{A. Dignidad}

El Titulo I, con la acertada rúbrica de "Dignidad", se va ocupando de aspectos básicos, como "Dignidad humana" (1), -y advierto que, en principio, daré el rótulo del precepto y el número de éste-, "Derecho a la vida" (2), "Derecho a la dignidad de la persona” (3), "Prohibición de la tortura y de las penas o tratos inhumanos o degradantes" (4) y "Prohibición de la esclavitud y del trabajo forzado" (5). Queda excluida así la pena de trabajos forzosos y, sobre todo -habrá

\footnotetext{
66 Sobre lo que había insistido especialmente, como se dijo, el "Informe Pintasilgo", de 1996, y recalcaría tres años después el "Informe Simitis".
} 
que recalcarlo con énfasis, pues es uno de los símbolos relevantes de "la cultura europea de los derechos humanos"-, queda erradicada la pena de muerte en línea con lo que había ido avanzando el Derecho constitucional de diversos Estados, reflejado así en algunas Constituciones más recientes, como la española de 1978, con el significado de su artículo 15, con el impulso decisivo luego de lo dispuesto por los Protocolos Adicionales 6 y 13 al CEDH. Importante mensaje que los órganos responsables de la Unión, lo mismo que los juristas o los profesores europeos, no deberían cansarse de recordar y transmitir por doquier. Pero, con todo, seña de identidad de la que hay que enorgullecerse, a la par que se intenta proteger lo que significa.

\section{B. Libertades}

63. Bajo la rúbrica "Libertades", el Título II incluye un destacado puñado de ellas, siguiendo la pauta del CEDH y de sus Protocolos, entre las que se encuentran el "Derecho a la libertad y a la seguridad" (6), el "Respeto a la vida privada y familiar" (7), "Protección de datos de carácter personal" (8), el "Derecho a contraer matrimonio y a fundar una familia" (9), "Libertad de pensamiento, de conciencia y de religión" (10), "Libertad de expresión y de información" (11), poniendo énfasis como algo diferenciado de lo anterior en "Libertad de las artes y de las ciencias" (13), "Libertad de reunión y de asociación” (12), "Derecho a la educación” (14), "Libertad profesional y derecho a trabajar" (15), "Libertad de empresa” (16), "Derecho a la propiedad" (17), "Derecho de asilo" (18) y, con referencia también a los extranjeros, "Protección en caso de devolución, expulsión y extradición” (19). Este último precepto, que tanto debe al sistema de Estrasburgo, consagra definitivamente la superación de una pesadilla que tanto ha pesado en la historia de Europa, y no sólo en los tiempos remotos, la de las expulsiones colectivas, que ahora se prohíben $^{67}$. Destacaré, como detalle curioso, que España, que al igual que otros Estados de la

67 Tal criterio, que es el apartado 1 del precepto, representa, como se puntualiza con toda precisión en "las Explicaciones", la incorporación literal del artículo 4 del Protocolo número 4 al $\mathrm{CEDH}$, mientras que la regla del apartado 2, al prohibir la extradición cuando se tema tortura o sometimiento a tratos inhumanos o degradantes, refleja una construcción de la jurisprudencia del TEDH, a partir sobre todo del famoso asunto "Soering c. Reino Unido", de 1998. Recuérdese el importante trabajo que le dedicó tempranamente el profesor GARCÍA DE ENTERRÍA, y que tanto contribuyó a su conocimiento: El principio de proporcionalidad en la extradición. Derecho a no ser extraditado, pena de muerte como pena o trato inhumano o degradante, control de la proporcionalidad de las decisiones gubernamentales sobre extradición y otras cuestiones sustantivas en la sentencia "Soering", de 7 de julio de 1989, del TEDH, 35 ss.. 
Unión, no se había comprometido con esta fórmula, en cuanto tardó muchísimo en ratificar el Protocolo número 4, pasa, a través de la Carta, a quedar vinculada con la misma. ¡Curiosos efectos de la eficacia del nuevo texto! ${ }^{168}$. Ahora sí, el Protocolo número 4 fue ratificado por España, el 16 de septiembre de 2009, entrando en vigor el mismo día ${ }^{69}$.

64. Por otro lado, no será ocioso recordar con carácter general que cuando la Carta asume textos del CEDH, como sucede en abundancia en este título -aunque también en otros-, se están recibiendo, a veces literalmente, ideas que habían sido plasmadas en la Declaración Universal de Derechos Humanos. ¡Siempre es importante reflexionar acerca de la continuidad, aparente o difusa, de los grandes pasos que se van logrando en el proceso de protección de los derechos humanos.

\section{Igualdad}

65. A la "Igualdad" se le dedica señalada importancia en el Título III, que arranca de la importante afirmación de que "Todas las personas son iguales ante la ley" (20), precepto de tan hondo significado histórico -y sobre los avatares de cuya elaboración algo se dijo-, para ir luego concretando alguno de los aspectos particulares: "No discriminación" (21), "Respeto a la diversidad cultural, religiosa y lingüística" (22), "Igualdad entre mujeres y hombres" (23),

68 Hacia marzo de 2010 daba la prensa la noticia de que Turquía, disgustada por la condena del llamado "Holocausto Armenio" por Estados Unidos y Suecia, amagaba con la expulsión colectiva de un buen número de armenios residentes en Turquía, de manera ilegal al parecer. No sé si será fidedigna la información periodística, ni si se trataba de una amenaza real o de pura fanfarronería, pero con todo, y por si acaso, diré, primero, que no me cabe duda de que los Estados disponen de medios para combatir las ilegalidades de acuerdo con el Derecho. Pero añadiré, que de haber ingresado Turquía en la UE, no estaría autorizada tras la Carta para llevar a cabo una expulsión colectiva. ¡Es muy importante que no resuciten los viejos demonios, pues impresiona todavía recordar las ingentes migraciones forzadas de griegos y turcos producidas en los ańos veinte del siglo pasado.

69 Por cierto que me agrada recordar que cuando en abril de 2006 criticaba la fórmula que han generalizado con alegría los nuevos Estatutos de Autonomía de codificar determinados derechos para los ciudadanos de su territorio, objetaba, al referirme al sistema del CEDH y a los Protocolos que lo han ido completando: "Causa por ello sonrojo que nuestro Estado, es decir el Reino de España, no haya ratificado todavía varios de esos Protocolos adicionales, a través de los cuales se pretende incorporar nuevos derechos. E, insisto, las fuerzas políticas que aspiran a consagrar diferencias entre españoles, al propiciar en los Estatutos de Autonomía la innovación criticada, bien podrían dirigir sus esfuerzos a poner a nuestro Estado al día ante tan incitantes retos europeos: ¡nuevos derechos, pero para todos!". Véase mi trabajo, Derechos humanos y Estatutos de Autonomía, 150. 
"Derechos del niño" (24), "Derechos de las personas mayores" (25), e "Integración de las personas discapacitadas" (26).

66. El artículo 22, que es un precepto que se añadió al final, y que es una síntesis de algo que contemplaban ya los Tratados, incorpora la vieja preocupación tan presente en la tortuosa historia de tantos territorios de Europa, y que no ha perdido actualidad, de la integración de las minorías. Creo por eso que se trata de un tema importantísimo sobre el que quiero llamar la atención expresamente. No pocos territorios, especialmente en la Europa Central y oriental, por muy diversas causas, sobre todo debido a la alteración de fronteras, han conocido muy agudos problemas de convivencia, dada la presencia de cualificadas minorías bien presentes. Poco será, por eso, todo lo que se haga para que, sin perjuicio de dejar abiertas las puertas para una posible integración voluntaria, acaso paulatina, puedan conseguir un espacio social en el que se encuentren a gusto y puedan así fluir, en el respeto a las diferencias, relaciones de convivencia armoniosas. Ello, sin perjuicio de los posibles nuevos problemas que puedan abrir las constantes migraciones propias de un mundo que se nos va quedando pequeño y en el que cada vez las fronteras cuentan menos.

\section{Solidaridad}

67. El Título IV se dedica a "Solidaridad" y es el que va a albergar mayor número de derechos sociales. Recuérdese que la excepción que el Protocolo número 30 proclama para Polonia y el Reino Unido -ampliable en el futuro a la República Checa-, se refiere fundamentalmente a este Título. De hecho, en los preceptos incluidos en él abundan las opciones de contenido prestacional. De ahí que se forzaran, al elaborar la Carta, las llamadas expresas a la ley o, lo que es lo mismo, al legislador, que es quien deberá concretar el alcance de los preceptos ${ }^{70}$. Y que, en efecto, como se razonó, a la hora de la verdad, cuando no basta con un mero dejar hacer sino que hay que llevar a cabo aportaciones efectivas, es normal que los Estados quieran tener sus cuentas claras. Dígase lo mismo de la búsqueda del equilibrio razonable cuando en los aspectos laborales

70 Téngase en cuenta que el apartado 6 del artículo 52, que es un añadido que se incorpora al prepararse el proyecto de Tratado por el que se establece una Constitución para Europa, dispone: "Se tendrán plenamente en cuenta las legislaciones y prácticas nacionales según lo especificado en la presente Carta”. 
se enfrenten trabajadores y empresarios, presidido todo ello por la idea central en la Unión de obrar "en pro del desarrollo sostenible de Europa basado en un crecimiento económico equilibrado y en la estabilidad de los precios, en una economía social de mercado altamente competitiva tendente al pleno empleo y al progreso social", como dispone el artículo 3.3 TUE.

68. Se abre la lista con el "Derecho a la información y consulta de los trabajadores en la empresa" (27) y sigue con el "Derecho de negociación y acción colectiva" (28). Este precepto concluye con una referencia expresa a la huelga, que fue uno de los puntos calientes y polémicos a lo largo de la elaboración de la Carta. De hecho, sólo al final se consiguió que se incluyera. Vienen a continuación, "Derecho de acceso a los servicios de colocación" (29), "Protección en caso de despido injustificado" (30), "Condiciones de trabajo justas y equitativas" (31), "Prohibición del trabajo infantil y protección de los jóvenes en el trabajo" (32) y "Vida familiar y vida profesional” (33). A destacar de este precepto, desde la importante perspectiva de intentar "conciliar vida familiar y vida profesional”, las garantías frente al despido laboral "por una causa relacionada con la maternidad". Siguen luego, "Seguridad social y ayuda social" (34), "Protección de la salud" (35), "Protección del medio ambiente" (37) y protección de los consumidores" (38).

En estos tres últimos preceptos el compromiso de los poderes públicos resulta mínimo, quedando abierto un enorme margen de maniobra para que luego concrete el legislador. Quiero por eso señalar una situación realmente paradójica. Es ingente la tarea que desde hace unos años viene realizando la Unión en orden a la protección del medio ambiente en sus más variados aspectos (y diré lo mismo en relación con la defensa de los consumidores). Hasta el punto de que bien podemos afirmar: ¡Qué sería de la naturaleza en España, en estos tiempos de depredadores y de ladrillo a toda costa -aunque sea en la propia costa-, si no fuera por la Unión Europea! Y es que resulta admirable, y tan esclarecedor, el criterio que desde hace tiempo luce en los Tratados, y que tanto me gusta encomiar, de que, "Las exigencias de la protección del medio ambiente deberán integrarse en la definición y en la realización de las políticas y acciones de la Unión, en particular con objeto de fomentar un desarrollo sostenible" (artículo 11 TFUE). Previsión luego desarrollada por tantísimas directivas y por una política activa continuada. Sorprende por eso que con tan incisiva y efectiva realidad cotidiana en pro de la protección del medio ambiente, luego el 
compromiso de la Carta sea tan escueto. Aparece de nuevo el viejo tema de las reservas y reticencias de los Estados a la hora de comprometerse, sin olvidar las tan diferentes sensibilidades y disponibilidades de los numerosos países integrantes de la Unión. Sin duda, esperamos mucho de la declaración de derechos, pero hay que consolarse pensando que no importa tanto que el precepto de la Carta sea en este punto tan laxo si luego, a la hora de la verdad, el impulso efectivo sigue siendo tan intenso y cuidadoso como hasta ahora.

69. Un último punto ahora para destacar el dato de que se haya llevado a la carta el respeto a la ordenación jurídica a la hora de garantizar el acceso a los servicios de interés económico general. El viejo y oscilante tema de los servicios públicos que aparece y desaparece según las necesidades y los medios para satisfacerlas, ha de variar en cuanto a contenidos y posibilidades, y por supuesto, denominación, pero responde as un criterio sano de ordenación social, que en cada momento histórico puede ofrecer bien diferentes exigencias ${ }^{71}$. De ahí que mientras existan, sean de agradecer las necesarias garantías jurídicas, que la Carta contempla expresamente en el artículo 36, al abordar el "Acceso a los servicios de interés económico general”72.

\section{E. Ciudadanía}

70. El Título V, sobre "Ciudadanía” reúne una serie de opciones por las que había apostado la Unión desde que en 1992, en el Tratado de Maastricht, se reguló la ciudadanía europea. En esos momentos, rebosando de vitalidad la idea europea, con muy cualificados líderes a la cabeza, tanto de Europa como de los Estados, bien lejos de los agobios económicos que en el momento actual parecen marcar la agenda de manera inexorable, se dio un gran impulso a la integración europea, con respuestas institucionales de gran calado. Pues bien, lo que entonces se llevó a los Tratados, y empezó a funcionar, terminó saltando con toda legitimidad a la Carta, que va abordando así, el "Derecho de sufragio activo y pasivo en las elecciones al Parlamento Europeo" (39), el "Derecho de sufragio activo y pasivo en las elecciones municipales" (40), el "Derecho de

\footnotetext{
$71 \quad$ Nos queda la curiosidad de saber como se va a articular, por ejemplo, la reciente propuesta del Presidente de los Estados Unidos de garantizar a toda la población de su país -y algo similar ha aventurado el "Premier" británicoel acceso a banda ancha de calidad al objeto de poder utilizar la red.

72 Me remito a mi trabajo, El derecho de acceso a los servicios de interés económico general, págs. 535 ss.
} 
acceso a los documentos" (42), "El Defensor del Pueblo Europeo" (43), "Derecho de Petición” (44), "Libertad de circulación y de residencia" (45), así como "Protección diplomática y consular" (46). Se trata, en general de preceptos que tienen que ver con el funcionamiento de la Unión y que afectan de manera directa a su organización -facilitar el acceso a los documentos, facilitar el ejercicio del derecho de petición, asegurar el funcionamiento del Defensor del Pueblo Europeo y abrir los oportunos cauces de comunicación-, sin perjuicio de que en otros casos puedan derivarse obligaciones directamente a los Estados: admisión de la libre circulación, o adoptar las medidas oportunas a la hora de organizar las elecciones al Parlamento Europeo o, de forma más directa, asumir los nuevos criterios cuando se trate de organizar en el propio ámbito interno las elecciones municipales. El uso de la protección diplomática y consular se presenta ofreciendo un doble reflejo: ante todo, fuerza a los Estados a tener que atender eventualmente en su red diplomática y consular a cualquier ciudadano comunitario, con las complejas secuelas de orden administrativo que ello pueda representar. De otra parte, está abriendo oportunidades a los ciudadanos de la Unión que podrán así ver ampliada su red de atención en aquellos países a que no haya llegado su Estado.

71. Hay también un precepto que llama especialmente la atención. Lo mismo que las declaraciones de derechos han solido codificar un derecho a la correcta administración de justicia, se ha dado el paso de dar cabida en la Carta a un "Derecho a una buena administración" (41), que, en gran medida, sigue los pasos del derecho a la justicia, y que me viene interesando y atrayendo con cierta pasión desde que apareció en la Carta $^{73}$. Sorprende esta solución, pero hay que entender que forma parte de la apuesta por el buen funcionamiento de lo público en relación con los ciudadanos. Lo público se ha hecho muy complejo en el Estado Social de Derecho -no digamos si conviven con escaso sistema y con afán de diferenciarse y desconocerse diversos niveles de descentralización- y el ciudadano anda cada vez más perdido frente a las organizaciones. De ahí que se acoja con interés lo que pueda facilitar la tarea de los administrados. Hay que tener en cuenta, por otro lado, que el precepto sería de inequívoca aplicación en el ámbito de los Estados, cuando éstos estén dando aplicación al Derecho de la Unión, que como se dijo, ha de suceder cada vez con mayor frecuencia. En tales casos, estamos ante exigencias que han de ser respetadas

73 Véase así mi trabajo, Dos notas sobre la Carta, especialmente págs. 530 y sigs. 
por todos los niveles descentralizados que actúan dentro de un Estado, como serían en el caso de España -además de los órganos periféricos de la Administración General del Estado- las Comunidades Autónomas, las Diputaciones provinciales y órganos similares, los Municipios y demás. En puridad, sería un precepto que encajaría dentro de las competencias del Poder Central, a tenor de lo dispuesto en el artículo 149.1.18 a $\mathrm{CE}$, en relación con las bases del régimen jurídico de las Administraciones Públicas, el procedimiento administrativo común y el sistema de responsabilidad de las Administraciones. Recalco esta idea de la visión global y de conjunto porque, como es sabido, a disposición de todos la Carta desde hace más de diez años, algunos Estatutos de Autonomía se han adelantado para "apropiarse” el concepto, como si fuera invención suya, y desde la tónica de diferenciarse de los demás.

\section{F. Justicia}

72. Queda por referir, en último término, el Título VI, dedicado a "Justicia", partida ciertamente determinante en toda declaración de derechos desde que éstas comenzaron a existir. El artículo 47 contempla de manera separada en sus dos primeros apartados, lo que son opciones bien diferentes, como me gusta recalcar, ${ }^{74}$ de una parte, el que tenga que haber siempre a disposición del ciudadano un recurso judicial efectivo cuando uno de los derechos fundamentales pueda resultar violado, y, de otra, el derecho a una justicia equitativa para cuando haya que acudir ante los tribunales, bien para litigar o para defenderse de una acusación. El apartado tercero incide en la asistencia jurídica gratuita para quienes no tengan recursos suficientes, Los preceptos siguientes abordan la "Presunción de inocencia y derechos de la defensa" (48), "Principios de legalidad y de proporcionalidad de los delitos y las penas" (49), así como el "Derecho a no ser juzgado o condenado penalmente dos veces por una misma infracción” (50).

\section{G. Criterios de funcionamiento}

\footnotetext{
$74 \quad$ Me remito a mi trabajo, La defensa de los derechos fundamentales: tres diferentes cauces jurisprudenciales en la Constitución española, especialmente, págs.89 y sigs.
} 
73. Me importa fundamentalmente el contenido sustantivo de la Carta pero no me parece correcto concluir su exposición sin advertir, aunque sea de forma sucinta, que hay un último título, el VII, a modo de cajón de sastre, si formalmente dedicado a sentar los criterios de aplicación, como dice expresamente el rótulo, a "Disposiciones que rigen la interpretación y aplicación de la Carta”, lo cierto es que hay algo más. A alguno de los preceptos referentes a la aplicación de la Carta ya se ha aludido antes, en cuanto el artículo 51 contempla el "Ámbito de aplicación”, y en el 52 donde se aborda el “Alcance e interpretación de los derechos y principios”, alguno de los apartados han sido también referidos en cuanto contemplan la metodología para los principios $\left(5^{\circ}\right)$, o remachan el valor de la legislación y prácticas nacionales $\left(6^{\circ}\right)$.

Pero no quiero dejar de mencionar que en este título han hallado cabida dos importantes reglas del $\mathrm{CEDH}$. De una parte, el criterio de posibles limitaciones de los derechos fundamentales, que el Convenio incluye, en general, en el apartado segundo de algunos preceptos, pero que en la Carta se concentra la regla -al igual que el modelo originario, el artículo 29.2 DUDH-, reclamando que para que las limitaciones sean posibles debería disponerlo así la ley, se trate de proteger determinados intereses generales y se respete el principio de proporcionalidad. Tal es lo que se dispone en el apartado primero del artículo 52. De gran interés también la regla del Convenio (artículo 17) que proclama el principio de no libertad para los que la quieren para acabar con la libertad, que bajo el mismo rótulo de "Prohibición del abuso del derecho", acoge el artículo final de la Carta, el 54, reproducción literal, con las debidas adaptaciones de aquél precepto del Convenio.

74. Dos palabras sólo para recordar, por razones sistemáticas, algo de lo que ya se ha hablado reiteradamente: se ha añadido al artículo 52 un apartado 7 para imponer que los órganos jurisdiccionales que apliquen los preceptos de la Carta, ya sean los de la Unión, ya los de los Estados miembros, habrán de tener en cuenta las "explicaciones” preparadas al elaborarse la Carta. Con lo que, a lo que era un documento del proceso interno se le da una importancia desorbitada pues, en puridad, cuando se hable hoy de la Carta habrá que tener en cuenta que se está aludiendo a ésta más las citadas "explicaciones". Lo que, aparte de otras consecuencias tranquilizantes, por así decir-, se afea enormemente el documento dado que toda declaración de 
derechos, como se dijo, aspira a la concisión en el empeño de ofrecer un texto cincelado y expresivo, que pueda fácilmente consultarse y retenerse, elegancia y concisión que de ninguna manera, casi por definición, se encuentra en las citadas "explicaciones". Se amplia, por tanto, la prosa a tener en cuenta por lo que hoy en las ediciones al uso no va a ser correcto ya ofrecer sólo el articulado de la Carta.

\section{COLOFÓN}

75. Llegamos así al final de esta reflexión acerca de la trabajosa cuanto rica evolución en los intentos por arraigar un caudal respetable de DDFF en el seno de las Comunidades Europeas, hoy ya la Unión Europea. Se ha glosado la complicada travesía de la Carta, texto ya definitivamente consagrado, y que ahora deberá comenzar a arraigar. Texto que no es un islote aislado. A su lado, en esa rica y compleja situación de vasos comunicantes que caracteriza la relación entre la UE y los Estados miembros, siguen estando las Constituciones nacionales, alimentando las tradiciones constitucionales comunes, sigue estando el $\mathrm{CEDH}$, expresamente asumido por todos los Estados de la Unión, con el incesante flujo de su innovadora jurisprudencia, del mismo modo que aquellos mandatos que se han llevado a la Carta tomados de los Tratados, siguen estando en éstos. Un poco, la imagen de los DDFF en la UE podría ser la de un glaciar donde se han hecho unidad una vez incorporadas aguas de tan diverso origen, y una vez acumuladas se van desplazando conjuntamente.

Para terminar, yo quiero encomiar de nuevo la importancia de la Carta de Derechos Fundamentales de la Unión Europea, sin ofuscaciones ni triunfalismos, sin dejar de ser consciente de sus carencias y limitaciones. Se trata de un paso bien destacable, un dato señaladamente positivo de la organización europea, muy presentes siempre tantas crueldades que a lo largo de siglos se cometieron en estas tierras, algunas -como en los Balcanes- bien recientes todavía. Si bien no todo lo que se quisiera, es mucho lo que se ha conseguido. Por otro lado, bien sabemos que si es determinante alcanzar una declaración de derechos, tal acto no debe ser visto nunca como un punto de llegada, sino más bien como un punto de partida. Aunque sean necesarias, más aún, imprescindibles, está claro que en el mundo del derecho más importante que las normas 
resulta su aplicación y el afán por hacerlas efectivas. Se resalta, por tanto, la necesidad inexcusable de que, sin excusas ni dilaciones, los derechos fundamentales lleguen a cobrar vida real. Lo que implica alcanzar un clima social en que sean respetados. Para lo cual, para que puedan alcanzarse los objetivos vislumbrados tal como los define la Carta, son necesarios ingentes esfuerzos, abundante normativa complementaria, cuantiosas medidas de apoyo e incluso la realización decidida de políticas específicas. Y siempre, educación, mucha educación, mantenida con ilusión y sin desmayo en toda la cadena de centros e instituciones docentes, afianzada también por quienes crean opinión pública. Se requerirá que los ciudadanos sepan cuales son sus derechos, aprendan a defenderse en caso de agravio, y asuman también que tienen que respetar los derechos de los demás. Lo mismo que autoridades y funcionarios tienen que concienciarse para adecuar su conducta a las exigencias de la nueva declaración de derechos. En este sentido, parece auspiciable que los legisladores, tanto las Cortes Generales como las Asambleas Autonómicas, incorporen a su procedimiento de actuación el contraste de las nuevas normas que pretenden elaborar con las exigencias de la Carta, lo que vale también para los titulares de la potestad reglamentaria en los diversos niveles. Es decir, que la entrada en vigor de la Carta debería producir una viva movilización de energías para concienciar a quienes van a quedar obligados por la Carta, lo mismo que a los jueces y tribunales que hayan de llevar a cabo las tareas de supervisión y control.

76. En suma, yo creo que la Carta deberá ser considerada como un preciado símbolo europeo, un testimonio señero de lo que llamamos "la Europa de los derechos humanos", ese "espacio de justicia y libertad", tan difícil de conseguir históricamente como precisado de ser defendido y mantenido a toda costa. En este sentido, como ciudadano europeo, es un profundo motivo de satisfacción saber que uno está regido por una bien granada declaración de derechos, bajo cuya hégira se hallan a la par los muchos millones de personas que viven dentro de los confines de la Unión. Y es que en la larga historia de la afirmación de los derechos humanos siempre han jugado un papel decisivo las declaraciones de derechos que aspiraban a afirmarse más allá de las fronteras de los Estados ${ }^{75}$.

75 Por lo cual, no deja de ser un tanto divertido contemplar el espectáculo pueblerino de no pocos políticos locales entre nosotros, afanosos por hacer "su propia declaración de derechos", aprovechando el trámite de la reforma del correspondiente Estatuto de Autonomía, en una especie de carrerilla de emulación para intentar demostrar que 
Al comenzar se hablaba de lo simbólico. Yo creo que los símbolos tienen un destacado significado, no sólo en relación con los derechos fundamentales sino, en general, en la configuración del Poder. Quienes creímos en la importancia de la non nata Constitución Europea valoramos muy positivamente que se dedicara un artículo 8 a enumerar los símbolos de la Unión: la bandera, el himno, la divisa, la moneda así como el día conmemorativo. El proyecto de Constitución decayó y no ha pasado al Tratado de Lisboa lo referente a los himnos dada la reticencia de algunos Estados a que la Unión se configurara como un Estado, lo que arrastró consigo también a los símbolos. No faltaron, empero, como se recordó, algunos Estados que quisieron dejar sentado el gran valor que atribuían a los símbolos. Pues bien, se diga o no se diga, la más moderna declaración de derechos, la Carta, es, sin ninguna duda, aparte de otras cosas, un símbolo preclaro de Europa, un testimonio neto del sistema de valores que la Unión Europea viene profesando desde sus orígenes y que los europeos deberían honrarse en propagar. Yo no entiendo por eso por qué se ha sido tan pacato a la hora de ensalzar y proyectar la Carta -al menos por lo que yo he visto en España, aunque me da la impresión de que ha sucedido lo mismo en todas partes-, tan escasos los esfuerzos por darla a conocer y por acentuar el significado de su mensaje. Uno se imagina, por ejemplo, que en las visitas de los escolares a los Parlamentos Autonómicos, no digamos a las Cortes Generales, uno de los obsequios que deberían recibir sería un cuidado y atractivo ejemplar de la Carta. Cuando se escriben estas líneas, llevamos meses admirados por la reacción cívica en tantos países del norte de África y del oeste de Asia intentando alzarse tantos ciudadanos con armas tan sencillas como el ejercicio de la libertad de expresión y la libertad de reunión y de manifestación, frente a las tiranías que vienen dominando en sus territorios. Se aspira a la libertad, se auspicia la participación política, se denigra la represión y la tortura, subleva la presencia de la corrupción en los aledaños del poder, así como todo el ejemplar conjunto de reivindicaciones de tan fácil comprobación. Pues bien, funcionará la red y se facilitarán las convocatorias, pero todos sabemos lo importante que resulta que ya fuera por propia experiencia como testigos -trabajadores o viajeros-, o por lo que se ve en las televisiones y en el cine, en gran medida tan nobles reacciones han sido inducidas al conocer que hay otros

“yo soy más que los otros y que en mi territorio tenemos derechos de que otros carecen”. Pretensión que, por cierto, el Tribunal Constitucional no se ha recatado en enfriar echándole un buen jarro de agua fría. 
países en los que no hay lugar para tiranos y se practica una convivencia cívica radicalmente diferente. Sorprende la lentitud o la frialdad en la respuesta europea, pero debe quedar muy claro que tantos de los valores que lucen en la Carta es a lo que aspiran los manifestantes en los territorios citados: el derecho a la participación política y al control de los Gobiernos, el derecho a la vida y a los procesos justos, la erradicación de las detenciones arbitrarias, la libertad de expresión y la igualdad de oportunidades, el derecho a la educación y a la protección de la salud y todos los demás derechos sociales alcanzados en nuestra época. Curiosamente, todo eso está en la Carta. Quiero significar por eso que las instituciones de la Unión Europea, pero también cada uno de los Estados en singular, deberían cuidarse muy mucho de tratar de hacer llegar por doquier un documento tan relevante como la Carta, al igual que en otros tiempos circulaba, por ejemplo, la Declaración de Derechos del Hombre y del Ciudadano. Luego, cada uno hará lo que quiera, o lo que pueda, pero entiendo que debería ser incansable el esfuerzo por aprovechar cualquier oportunidad para que la Carta se propagara y conociera. Y es que con la Carta hay libertad de creencias y no hay una religión excluyente, lo mismo que se afianza la libertad de expresión y no hay monopolio informativo, se consagra la libertad para hacer política y crear organizaciones políticas y sindicales, sin el monopolio de ninguna familia o de ningún clan. En suma, y por cerrar ya el discurso, que la Carta tiene un gran papel que jugar, por de pronto en el ámbito de la Unión Europea ${ }^{76}$ pero, a su vez, como símbolo preclaro de un espacio de justicia y libertad, habría que esforzarse por darla a conocer allí donde pueda ser semilla de modernidad. En el mismo sentido, y sin falta, deberían esforzarse tanto las autoridades europeas como las de los Estados por intentar afianzar el principio de reciprocidad, cuando algunos de los derechos proclamados en la Carta sean desconocidos por los países con los que se entablan relaciones de intensidad ${ }^{77}$.

Madrid, 17 de mayo de 2011

\footnotetext{
76 Al hilo de estas consideraciones sobre la Carta, quiero decir sin falta, que a la vista del fiasco de algún Estado de los que han ingresado en la última ampliación, la Unión Europea debería detenerse para reflexionar si no habría que parar de momento la política de ampliación de nuevos miembros hasta lograr hacer arraigar los valores e ideales europeos en los miembros actuales, para lo cual, de nuevo, la profundización en la Carta es una excelente metodología.

77 El presente trabajo se enmarca en el proyecto de investigación DER 2008-06077, "La incidencia de la nueva ordenación europea de los DDFF en los sistemas jurídicos nacionales y la actuación de las Administraciones Públicas en su protección y desarrollo", del que yo mismo soy director.
} 


\section{Abreviaturas Utilizadas}

CARTA Carta de los Derechos Fundamentales de la Unión Europea

CE Constitución española de 1978

CEE Comunidad Económica Europea

$\mathrm{CEDH}$ Convenio Europeo para la Protección de los Derechos Humanos

y Libertades Fundamentales, hecho en Roma el 4 de noviembre de 1950

DDFF Derechos fundamentales

DUDH Declaración Universal de Derechos Humanos, de 10 de diciembre de 1948

TC Tribunal Constitucional

TCE Tratado Constitutivo de la Comunidad Económica Europea

TEDH Tribunal Europeo de Derechos Humanos (Estrasburgo)

TJUE Tribunal de Justicia de la Unión Europea (Luxemburgo)

TF Tratado de Funcionamiento

TL Tratado de Lisboa

TUE Tratado de la Unión Europea

UE Unión Europea

\section{Bibliografía}

\section{$\underline{\text { A. Textos normativos }}$}

Los Tratados y demás textos normativos pueden consultarse en:

- E. GARCÍA DE ENTERRÍA, A.TIZZANO y R. ALONSO GARCÍA, Código de la Unión Europea, 2a ed., Civitas, 2000.

- L. MARTÍN REBOLlO, Código de la Unión Europea, Aranzadi, 2002, y Leyes Administrativas, 16 ed., Aranzadi, 2010.

- L. MARTÍN REBOLLO, Leyes Administrativas, 16a edición, Aranzadi, 2010.

- R. ALONSO GARCÍA: las diversas ediciones de cada uno de los Tratados, en la "Serie menor", de Civitas.

- R. ALONSO GARCÍA y D. SARMIENTO, La Constitución Europea. Texto, antecedentes, explicaciones, Civitas, 2005. 
- R. ALONSO GARCÍA y Pablo GONZÁlEZ SAQUERO, Código de Derechos fundamentales, Civitas, 2010. En principio, el texto de la Carta y de las "Explicaciones", se citan por esta edición.

- R. ALONSO GARCÍA y María Astrid MUÑOZ GULTOSA, Tratados y legislación institucional de la Unión Europea, 4a edición, Civitas, 2010.

- J. MARTÍN Y PÉREZ DE NANCLARES y M. URREA CORRES, Tratado de Lisboa, Marcial Pons, 2008.

- G. GÓMEZ ORFANEL, Las Constituciones de los Estados de la Unión Europea, Centro de Estudios Constitucionales, 1996

- Ma. R. RIPOLLÉS SERRANO (coordinadora), Constituciones de los 27 Estados miembros de la Unión Europea, Congreso de los Diputados, 2011.

\section{B. Sistemática de la Unión Europea}

Puede verse, por todos:

- F. ALDECOA LUZURRAGA, La integración europea. Análisis histórico-institucional con textos y documentos, Tecnos, 2002

- R. ALONSO GARCÍA; Sistema jurídico de la Unión Europea, diversas ediciones en Civitas, la última de 2010.

- R. ALONSO GARCÍA, Derecho de la Unión Europea. Textos y materiales, Madrid, Civitas, 2010;

- L. MARTÍN REBOLLO, Estudio preliminar, a su citado, Código de la Unión Europea, $15-68$.

- L. MARTÍN REBOLLO, Estudio preliminar sobre los Tratados, el Derecho y las Instituciones europeas, en Leyes Administrativas, cit., 271-318.

- A. TRUYOL SERRA, La integración Europea, Tecnos 1999.

C. Visiones generales sobre los derechos fundamentales en la Unión Europea y, en concreto, sobre la Carta

Entre la numerosa bibliografía, me remito a:

- R. ALONSO GARCÍA, Derechos fundamentales y Comunidades Europeas, en Estudios sobre la Constitución Española. Homenaje al Profesor García de Enterría, II, Civitas, 1991, 800 sigs.

-R. ALONSO GARCÍA y D. SARMIENTO, La Carta de los Derechos Fundamentales de la Unión Europea. Explicaciones, concordancias, jurisprudencia. Civitas, 2006.

- J. A. CARRILLO SALCEDO, La protección de los derechos humanos en las Comunidades Europeas, capítulo XVIII del volumen colectivo, Tratado de Derecho Comunitario Europeo, II, Civitas, 1987.

- J. A. CARRILLO SALCEDO, Hacia una mayor efectividad del mecanismo de garantía del Convenio Europeo de Derechos Humanos, en el volumen colectivo "Derechos fundamentales y otros estudios”, I, El Justicia de Aragón, Zaragoza, 2009.

- E. GARCÍA DE ENTERRÍA, Derecho a no ser extraditado: sentencia "Soering", de 7 de julio de 1989, del TEDH, en "Poder Judicial", 15 (1989).

- E. GARCÍA DE ENTERRÍA, I diritti fondamentali, Universidad de Bolonia, 1992. 
- E. GARCÍA DE ENTERRÍA, La significación general del convenio europeo de Derechos Humanos, separata del "Anuario de Derecho constitucional y Parlamentario", 5 (1993), 29 ss.

- E. GARCÍA DE ENTERRÍA, Reflexión sobre el Proyecto de Constitución Europea, en el volumen,"Sesión solemne académica de investidura del Excmo. Sr. D. Eduardo García de Enterría como Doctor Honoris Causa", Universidad de Cantabria, 1995, 23 ss.

- A. MANGAS MARTÍN (Directora), Carta de los derechos Fundamentales de la Unión Europea. Comentario artículo por artículo. Fundación BBVA, 2008.

- L. MARTÍN-RETORTILLO, La Europa de los derechos humanos, Centro de Estudios Constitucionales, 1998.

- L. MARTÍN-RETORTILLO, Los derechos fundamentales y la Constitución y otros estudios sobre derechos humanos, El Justicia de Aragón, Zaragoza, 2009: en este volumen recopilatorio se hallan recogidos diversas trabajos sobre la temática y, en concreto, algunos que se han ido citando, como: Para una afirmación de los derechos fundamentales en la Unión Europea; El debate sobre la constitucionalización de los derechos fundamentales en la Unión Europea. Dos notas sobre la Carta; El derecho de acceso a los servicios de interés económico general (El artículo 36 de la Carta de los Derechos Fundamentales de la Unión Europea); La defensa de los derechos fundamentales: tres diferentes cauces jurisdiccionales en la Constitución Española; El orden europeo e interno de los derechos fundamentales y su protección jurisdiccional; Derechos humanos y Estatutos de Autonomía; Los derechos humanos y las libertades fundamentales según los Tratados en que se basa la Unión europea.

- L. MARTÍN-RETORTILLO, La doble funcionalidad de la Ley Orgánica por la que se autoriza la ratificación del Tratado de Lisboa (La Carta de Derechos Fundamentales de la Unión Europea en el "Boletín Oficial del Estado"), en "Revista Española de Derecho Europeo", 30 (2009), 135 sigs. - J. A. PASTOR RIDRUEJO, La Carta de Derechos Fundamentales de la Unión Europea y la adhesión al Convenio Europeo según el Tratado de Lisboa, en el volumen colectivo coordinado por J. GARCÍA ROCA y P. FERNÁNDEZ SÁNCHEZ, Integración europea a través de derechos fundamentales: de un sistema binario a otro integrado, Centro de Estudios P. y Constitucionales, 2009, 3 sigs.

- A. RODRÍGUEZ-BEREIJO, La Carta de Derechos Fundamentales de la Unión Europea, Universidad Autónoma de Madrid, 2000.

-A. TRUYOL SERRA, Los derechos humanos, 4a edición, Tecnos, 2000.

\section{Otros trabajos o libros citados.}

- R. ALONSO GARCÍA, Derecho Comunitario y Derechos Nacionales. Autonomía, integración e interacción, Abeledo-Perrot, Buenos Aires, 1999.

- R. ALONSO GARCIA e I. TORRES MURO, La ley británica de derechos humanos (Human Rights Act 1998): una evolución a conciencia, "Revista Española de Derecho Administrativo", 105 (2000), 5 y sigs.

- J. M. BAÑO LEÓN, Los derechos fundamentales en la Comunidad Europea y la competencia del juez nacional,

- O. BOUAZZA ARIÑO, El impacto de la jurisprudencia de Estrasburgo en materia de planificación y domicilio en el Derecho inglés, "Revista de Administración Pública", 164 (2004), 407 y sigs. 
- M. CARLÓN, El impacto de la trasposición de la directiva de Servicios en el régimen de los Colegios Profesionales, "Revista de Administración Pública", 183 (2010).

- J. A. CARRILLO SALCEDO, Hacia una mayor efectividad del mecanismo de garantía en el Convenio Europeo de Derechos Humanos, en el volumen colectivo, Derechos fundamentales y otros estudios, I, El Justicia de Aragón, 2009, 229 y sigs.

- E. GARCÍA DE ENTERRÍA, La Constitución como norma y el Tribunal Constitucional, Civitas, $1^{\text {a }}$ edición 1981, con numerosas ediciones posteriores.

- P. GARCÍA ESCUDERO MÁRQUEZ, Técnica legislativa y seguridad jurídica. ¿Hacia en control constitucional de la calidad de las leyes?, cuadernos Civitas 2010.

- J. GUILLÉN CARAMÉS, El estatuto jurídico del consumidor. Politica comunitaria, bases constitucionales y actividad de la Administración, Cívitas, 2002

- L. MARTÍN-RETORTILLO, La interconexión de los ordenamientos jurídicos y el sistema de fuentes del derecho, Civitas, 2004.

- L. MARTÍN-RETORTILLO, Vias concurrentes para la protección de los derechos humanos. Perspectivas española y europea, Civitas, 2006

- L. MARTÍN-RETORTILLO, La defensa cruzada de derechos: la protección del medio ambiente en la jurisprudencia del TEDH, "Revista Española de Derecho Administrativo", 132 (2006), 727 ss.

- L. MARTÍN-RETORTILLO, Los derechos electorales a la luz de la jurisprudencia del $T E D H$, en el volumen colectivo dirigido por Fabio PASCUA MATEO, Estado democrático y elecciones libres: cuestiones fundamentales de derecho electoral, Civitas, 2010, 17 ss.

- B. NOGUERA DE LA MUELA, el impacto de la Directiva de Servicios sobre el sector del comercio: en especial, el caso de Cataluña, "Revista de Administración Pública”, 184 (2011).

- R. RIVERO ORTEGA (Director), Mercado Europeo y reformas administrativas. La trasposición de la Directiva de Servicios en España, Civitas, 2009.

- F. SÁINZ MORENO SÁINZ MORENO y J. C. da SILVA OCHOA (Coordinadores), La calidad de las leyes, Parlamento Vasco, Vitoria, 1989 